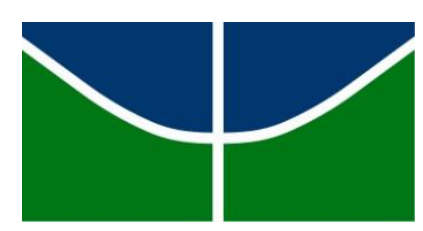

UNIVERSIDADE DE BRASÍLIA

INSTITUTO DE ARTES

PROGRAMA DE PÓS-GRADUAÇÃO EM ARTE

Cristiane Sobral Correa Jesus

\title{
TEATROS NEGROS E SUAS ESTÉTICAS NA CENA TEATRAL BRASILEIRA
}




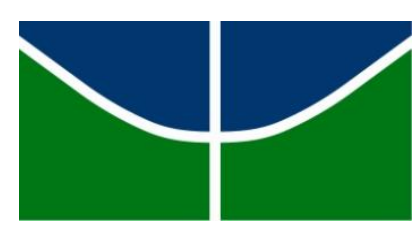

UNIVERSIDADE DE BRASÍLIA

INSTITUTO DE ARTES

PROGRAMA DE PÓS-GRADUAÇÃO EM ARTE

Cristiane Sobral Correa Jesus

\section{TEATROS NEGROS E SUAS ESTÉTICAS \\ NA CENA TEATRAL BRASILEIRA}

Dissertação apresentada ao Programa de PósGraduação em Arte como requisito para obtenção do grau de Mestra em Arte.

Orientadora: Dra. Roberta Kumasaka Matsumoto PPG-Arte/UnB. 


\author{
Cristiane Sobral Correa Jesus
}

\title{
TEATROS NEGROS E SUAS ESTÉTICAS NA CENA TEATRAL BRASILEIRA
}

Dissertação apresentada ao Programa de Pós-Graduação em Arte como requisito para obtenção do grau de Mestra em Arte.

Banca Examinadora:

Orientador:

Profa. Dra. Roberta Matsumoto

PPG-Arte/UnB

Membro interno:

Prof. Dr. Nelson Inocêncio

VIS/UnB

Membro externo:

Profa. Dra. Kátia Regina Costa Santos

SEPPIR

Suplente:

Profa. Dra. Luciana Hartmann

PPG-Arte/UnB 


\section{DEDICATÓRIA}

Dedico este trabalho ao meu esposo Jurandir Luiz, pelo amor e parceria, e aos meus filhos Malick Jorge e Ayana Thainá. 


\section{AGRADECIMENTOS}

À minha orientadora Roberta Kumasaka Matsumoto, pela confiança neste projeto, pelo incentivo, apoio, crítica, sugestões, convite à reflexão e escuta atenta em todas as etapas do trabalho.

Aos funcionários do Instituto de Artes, pela atenção e presteza na solução das demandas acadêmicas.

Aos professores Nelson Inocêncio, Kátia Santos, Fernando Villar, Geraldo Orthof e Luciana Hartmann, pelo aprendizado, sugestões, compartilhamento de ideias e incentivo fundamental no decorrer da pesquisa.

Aos colegas do mestrado, pelo compartilhamento de experiências e parcerias nos trabalhos do curso.

Aos companheiros do Fórum Nacional de Performance Negra.

Ao querido ator e produtor Hilton Cobra, exemplo de luta e enfrentamento em busca de soluções para a classe artística negra brasileira.

À minha sogra Lina dos Santos Luiz, exemplo e fonte de sabedoria.

Às minhas queridas profissionais de saúde, Thaís Moraes, Gabriela Camargo, Tamara Santos, pelo carinho e apoio, assim como pelas chaves para lidar com o corpo, o inconsciente e as questões criativas.

Aos meus colegas de trabalho da UNIEB Núcleo Bandeirante, em especial Ana Maria, Patrícia e Erasmo.

Aos queridos amigos Ricardo, Sandra, Isaac, Raisa, Cilinha, Leninha e Lara Arce, pelo ombro acolhedor, sincero e carinhoso.

A Dayse Sacramento.

À minha amiga mana, desde a infância no Rio de Janeiro, Carla Netto, Carlota.

A Laura, Lucas e Thyele Sane.

Muito obrigada a todos e todas! 
Até hoje, o negro tem sido um mero objeto de versões de cuja elaboração não participa. Em todas estas versões se reflete perspectiva de que se exclui o negro como sujeito autêntico. Autenticidade - é a palavra que, por fim, deve ser escrita. Autenticidade para o negro significa idoneidade consigo próprio, adesão e lealdade ao repertório de suas contingências existenciais, imediatas e específicas. E na medida em que ele se exprima de modo autêntico, as versões oficiais a seu respeito se desmascaram, e se revelam nos seus intuitos mistificadores, deliberados ou equivocados. O negro na versão de seus "amigos profissionais". E dos que, mesmo de boa-fé, o vêm de fora, é uma coisa. Outra-é o negro desde dentro.

Guerreiro Ramos 


\section{RESUMO}

Este trabalho procurará refletir sobre a trajetória de alguns artistas independentes e grupos de teatro negro brasileiro que atuaram antes e depois do Teatro Experimental do Negro, companhia teatral criada nos anos 1940 por Abdias do Nascimento, mapeando suas especificidades, singularidades estéticas, conquistas, avanços e desafios impostos pela realidade do cenário cultural brasileiro. E por sabermos que os artistas negros de ontem e de hoje ainda são caracterizados a partir de estereótipos herdados do período do escravagismo no país, o que faz com que tenham pouca inserção na cena teatral, o Fórum Nacional de Performance Negra, e seu alcance e debates, será um dos universos explorados por esta pesquisa, principalmente a partir de seu Grupo de Trabalho (GT) intitulado "Investigações Estéticas da Performance Negra". Como veremos, o referido fórum evidencia que, mesmo diante de um universo de adversidades, indivíduos e coletivos negros têm se organizado e resistido, apesar das escassas oportunidades, criando seus próprios núcleos de atuação com um teatro engajado, produtor de modos de fazer próprios, adaptados às suas especificidades. $\mathrm{E}$ como não poderia deixar de ser, este trabalho apresentará também uma reflexão crítica acerca do meu percurso como mulher-negra-atriz-diretora-escritora, destacando as principais produções teatrais com as quais estive e tenho estado envolvida na minha caminhada, assim como minha atuação junto à Cia de Arte Negra Cabeça Feita. Dessa maneira, embasada nos aportes teóricos sobre o teatro negro desenvolvido pelas especialistas Miriam Mendes e Leda Martins, esta dissertação pretende, finalmente, apresentar proposições no campo das estéticas cênicas fundamentadas nas matrizes africanas e afro-brasileiras, com o objetivo de refletir sobre o teatro negro e seus processos metodológicos e estéticos de forma a contribuir para a inserção dos estudos e produções teatrais negras no teatro brasileiro.

Palavras-chave: Teatro negro. Racismo. Estética negra. Teatro brasileiro. 


\begin{abstract}
This work aim to reflect on the trajectory of some independent artists and black theater groups in Brazil, those who came before and after the Black Experimental Theater, a theater company created in the 1940s by Abdias do Nascimento, mapping their characteristics, aesthetic singularities, achievements, progress and challenges posed by the reality of the Brazilian cultural scene. Being aware that black artists of yesterday and today are still being characterized according to stereotypes inherited from the slavery period in the country, which means they have little insertion in the national theater scene, the National Forum for Black Performance, and its range and debates, will be one of the venues explored by this research; mainly from its Working Group (WG) entitled "Aesthetic Investigations of the Black Performance". As we shall see, this National Forum shows that despite the adversities and the lack of opportunities individuals and black collectives have organized and resisted creating their own performance cores with an engaged theater, with a distinct way of conception adapted to their specificities. As should be expected, this work will also present a critical reflection about my journey as a woman-black-actress-director-writer, highlighting the main stage productions with which I was and have been involved in my journey as well as my performance with the Cia de Arte Negra Cabeça Feita group. Therefore, based on the theoretical contributions about black theater developed by experts such as Miriam Mendes and Leda Martins, this dissertation intends as well to present propositions for the field of performance based on the African and afro-Brazilian matrixes, in order to reflect on the black theater and its methodological and aesthetic processes aiming on the contribution to the integration of studies and black theatrical productions in the Brazilian theater.
\end{abstract}

Keywords: Black theater. Racism. Black aesthetics. Brazilian theater. 


\section{LISTA DE FIGURAS}

Figura 1 - Artistas que trabalham individualmente, grupos, coletivo e outros agrupamentos em todas as regiões

Figura 2 - Artistas reunidos no GT, em dezembro de 2015

Figura 3 - Siré Obá, a festa do rei. Grupo NATA - atores ao fundo, da esquerda para a direita: Thiago Romero, Deilton José, Cosme Lucian. À frente: Antônio Marcelo e Fabíola Júlia.

Figura 4 - Cena do espetáculo Siré Obá, a festa do rei. Grupo NATA. Direção: Fernanda Júlia. Em cena, os autores: Nando Zâmbia e Fabíola Júlia

Figura 5 - Bando de Teatro Olodum (BA). Em cena: Valdinéia Soriano, Auristela Sá, Jamile Alves, Telma Sousa e Arlete Dias (de pé). Deitados: Jorge Washington, Fábio Santana, Sérgio Laurentino, Cell Dantas e Ednaldo Muniz

Figura 6 - Atores em cena: Auristela Sá (in memoriam), Ednaldo Sérgio Laurentino,

Valdinéia Soriano, Gerimias Mendes, Jorge Washington, Ridson Reis e Telma Sousa 83

Figura 7 - Logotipo da Cia de Arte Negra Cabeça Feita. Criação: Edson Duavy ..... 91

Figura 8 - Dra. Sida - essa mulher vai fazer a sua cabeça 94

Figura 9 - Petardo, será que você aguenta? 95

Figura 10 - Estátuas de sal. Em cena: Cristiane Sobral, Thiago Jorge e Zizi Antunes 96

Figura 11 - Uma boneca no lixo. Em cena: Cristiane Sobral, 1998. Sala Saltimbancos do Instituto de Artes da UnB 100

Figura 12 - Dez anos depois (2008). Mostra Dulcina. Teatro Dulcina. Brasília 101 


\section{LISTA DE QUADROS}

Quadro 1 - Edições do Fórum Nacional de Performance Negra ...........................................59

Quadro 2 - Distribuição de grupos e de artistas por região e atividade..................................62

Quadro 3 - Grupos que responderam ao questionário ................................................... 72

Quadro 4 - Artistas independentes que responderam ao questionário ................................. 72 
INTRODUÇÃ

CAPÍTULO I - O NEGRO NO TEATRO ..................................................................24

1.1. O teatro brasileiro e os intérpretes negros nos primórdios da cena teatral nacional 31

1.2. O artista negro como objeto da representação cômica e estereotipada..................... 34

1.3. Pequeno escol de artistas negros e companhias do início do século XX................. 37

1.4. Teatro Experimental do Negro - 1944-1961 ........................................................ 47

1.5. O legado de três companhias de teatro formadas por artistas negros .......................54

CAPÍTULO II - ESTÉTICAS NEGRAS NA CENA CONTEMPORÂNEA ...............57

2.1. O Fórum Nacional de Performance Negra ...........................................................57

2.2. Apontamentos do GT do IV Fórum Investigações Estéticas - Pistas e espaços demarcados pelos artistas negros contemporâneos ........................................................... 64

2.3. Reflexão sobre os questionários - IV Fórum, dezembro de 2015 ........................... 71

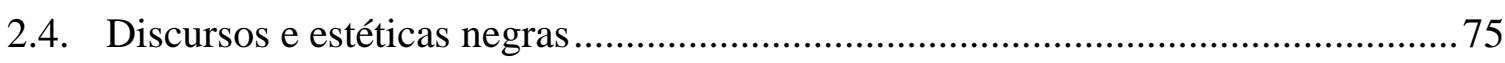

CAPÍTULO III - EU, NEGRA-ATRIZ-DIRETORA-ESCRITORA NO PLANALTO

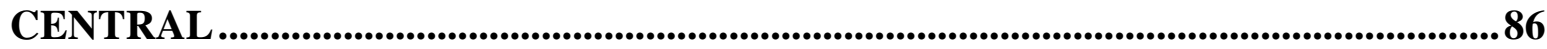

3.1. Cia de Arte Negra Cabeça Feita - Formação ............................................................ 91

3.2. Cia de Arte Negra Cabeça Feita - Trajetória........................................................... 93

CONSIDERAÇÕES FINAIS - RASURAS NO CÂNONE .......................................111

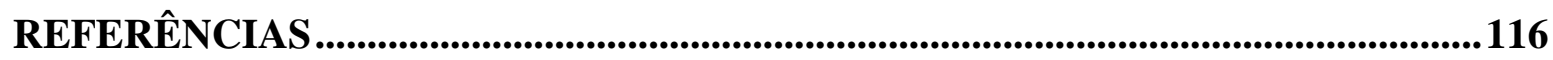

APÊNDICE - QUESTIONÁRIOS .................................................................................121

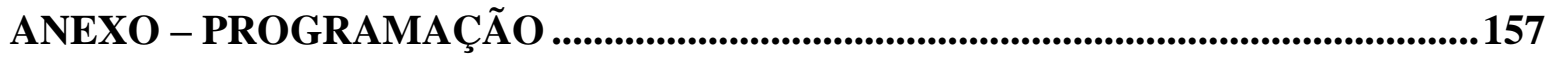




\section{INTRODUÇÃO}

Esta dissertação tem por objetivo analisar e refletir sobre algumas contribuições de artistas independentes e coletivos negros para a formação de estéticas teatrais fundamentadas na história, nas tradições e na ancestralidade africana e afro-brasileira. Essas estéticas, que levam aos palcos o jeito de ser e de viver da gente negra brasileira, congregando arte e política, ainda enfrentam muitos desafios para o seu reconhecimento e para a ampliação de oportunidades no mercado artístico nacional e nas academias, onde ainda predominam os moldes do cânone. ${ }^{1}$

Nos estudos da historiografia cênica nacional, poucas pesquisas abordaram o tema, poucos capítulos foram dedicados aos artistas e coletivos negros, raramente publicados e difundidos, ainda marginalizados, desconhecidos do grande público e dos estudiosos. Mesmo com os treze anos do advento da Lei $n^{\mathbf{o}} 10.639 / 2003,{ }^{2}$ lei federal que institui a obrigatoriedade do ensino de História e Cultura Africana e Afro-Brasileira nas escolas, essas temáticas ainda são trabalhadas com escassez nos bancos escolares. Faltam professores qualificados, materiais didáticos, fiscalização e acompanhamento da aplicação da lei. Também urge que as instituições de ensino superior se comprometam com o ensino no contexto dessas temáticas, promovendo as devidas reformulações nos currículos das

\footnotetext{
${ }^{1}$ Segundo a professora e pesquisadora Zahidé Luppinaci Muzart, em seu artigo intitulado "A questão do cânone", o estudo do cânone está ligado, pois, a várias coisas, principalmente à dominante da época: dominantes ideológicas, estilo de época, gênero dominante, geografia, sexo, raça, classe social e outros. Revista Anuário de Literatura. Universidade Federal de Santa Catarina. Florianópolis, n. 3, p. 85-94, 1995.

${ }^{2}$ A Lei no 9.394, de 20 de dezembro de 1996, passa a vigorar acrescida dos arts. 26-A, 79-A e 79-B:

"Art. 26-A. Nos estabelecimentos de ensino fundamental e médio, oficiais e particulares, torna-se obrigatório o ensino sobre História e Cultura Afro-Brasileira.

$\S 1^{\circ} \mathrm{O}$ conteúdo programático a que se refere o caput deste artigo incluirá o estudo da História da África e dos Africanos, a luta dos negros no Brasil, a cultura negra brasileira e o negro na formação da sociedade nacional, resgatando a contribuição do povo negro nas áreas social, econômica e política pertinentes à História do Brasil. $\S 2^{\circ}$ Os conteúdos referentes à História e Cultura Afro-Brasileira serão ministrados no âmbito de todo o currículo escolar, em especial nas áreas de Educação Artística e de Literatura e História Brasileira.

Lei $n^{\circ} 11.645 / 08$. Altera a Lei $n^{\circ} 9.394$, de 20 de dezembro de 1996, modificada pela Lei $n^{\circ} 10.639$, de 2003, que estabelece as diretrizes e bases da educação nacional, para incluir no currículo oficial da rede de ensino a obrigatoriedade da temática "História e Cultura Afro-Brasileira" e art. 1. O art. 26-A da Lei n 9.394, de 20 de dezembro de 1996, passa a vigorar com a seguinte redação:

"Art. 26-A. Nos estabelecimentos de ensino fundamental e de ensino médio, públicos e privados, torna-se obrigatório o estudo da história e cultura afro-brasileira e indígena.

$\S 1^{\circ} \mathrm{O}$ conteúdo programático a que se refere este artigo incluirá diversos aspectos da história e da cultura que caracterizam a formação da população brasileira, a partir desses dois grupos étnicos, tais como o estudo da história da África e dos africanos, a luta dos negros e dos povos indígenas no Brasil, a cultura negra e indígena brasileira e o negro e o índio na formação da sociedade nacional, resgatando as suas contribuições nas áreas social, econômica e política, pertinentes à história do Brasil.

$\S 2^{\circ}$ Os conteúdos referentes à história e cultura afro-brasileira e dos povos indígenas brasileiros serão ministrados no âmbito de todo o currículo escolar, em especial nas áreas de educação artística e de literatura e história brasileiras." Disponível em: <http://www.planalto.gov.br/ccivil_03/leis/2003/L10.639.htm>. Acesso em: 15 ago. 2016.
} 
licenciaturas e cumprindo seu papel na formação de futuros professores mais preparados e conscientes da importância dessas discussões, considerando as demandas da sociedade no que se refere às culturas africanas afro-brasileiras e indígenas.

As temáticas negras sempre encontraram portas estreitas na cena brasileira, embora os artistas negros tenham atuado no teatro brasileiro desde seus primórdios, segundo a concepção de Miriam Mendes (1993). No período do escravagismo, negras e negros foram convocados para atuação teatral em apresentações para os visitantes da casa-grande, em ocasiões festivas - só para destacar alguns dos espaços. Com a chegada ao Brasil da coroa portuguesa e a construção dos primeiros teatros nacionais no final do século XIX, os atores afro-brasileiros passaram a ser preteridos na cena.

Entretanto, as manifestações artísticas africanas e afro-brasileiras não deixaram de existir, ocupando o espaço das ruas, dos quintais, dos terreiros, territórios culturais urbanos. Até hoje, a minoritária participação das personagens negras no teatro brasileiro tem se mostrado tão imanente quanto a reprodução de ideias repetidas e pouco originais no sentido de desumanizar as poucas participações dessas personagens nos textos. Essa negação torna-se ainda mais persistente quando os temas abordados referem-se ao negro, à sua cultura, à sua história e suas tradições, em virtude da permanência de preconceitos relacionados à cultura afro-brasileira, cento e vinte e sete anos depois da "abolição" da escravatura.

Minha caminhada no mundo das artes cênicas começou nos anos 1980, aos onze, doze anos, no bairro de Santíssimo, ${ }^{3}$ loteamento de Coqueiros, ${ }^{4}$ bairro de classe média baixa na zona oeste do Rio de Janeiro, onde morava.

$\mathrm{Na}$ igreja protestante que frequentava com minha mãe, Igreja Adventista do Sétimo Dia, comecei a fazer pequenas participações em peças cristãs apresentadas em eventos da congregação, impulsionada por minha mãe, líder na igreja e na comunidade onde vivíamos. Nasceu aí o meu amor pelo teatro.

Por volta dos treze, quatorze anos, ao comentar com familiares e amigos sobre o meu desejo de atuar, ouvi que seria melhor desistir, porque o teatro não era considerado como profissão, era um espaço muito fechado, restrito, reservado para os filhos de artistas e pessoas com fenótipo europeu, salvo algumas exceções. Nesse momento comecei a pensar que o teatro, considerando a forma como acontecia na época, talvez não oferecesse um espaço profissional para meninas negras e moradoras de subúrbio como eu.

\footnotetext{
${ }^{3}$ Santíssimo é um bairro de classe média baixa e classe média da Zona Oeste do Rio de Janeiro pertencente à região da Grande Bangu.

${ }^{4}$ Coqueiros é um sub-bairro de Santíssimo, localizado às margens da Av. Brasil e onde se encontram a Estrada Sete Riachos, Estrada dos Coqueiros e Estrada da Posse.
} 
Ainda não tinha condições de perceber que o teatro brasileiro havia sido constituído a partir do modelo herdado do período colonial e que os grupos minoritários, fora do padrão vigente, como o dos negros, tiveram raríssimas participações. Nos casos em que eram caracterizados como personagens, costumavam ser tratados de forma estereotipada.

O estereótipo, ${ }^{5}$ segundo Miriam Garcia Mendes (1993, p. 29), se constitui por meio da generalização de conceitos sobre as pessoas e o coletivo. Impressões negativas de subalternidade e inferioridade sobre as etnias negras costumavam ser divulgadas, tendo em vista a ideologia escravocrata que regia a sociedade brasileira, ao longo dos quatro primeiros séculos da história do Brasil.

Os palcos brasileiros foram construídos a partir do modelo colonial europeu, ou seja, não incorporaram a especificidade dos intérpretes negros e suas matrizes culturais. $\mathrm{O}$ teatro brasileiro não foi constituído para contar a história das culturas africanas e afrobrasileiras. ${ }^{6}$ Os temas africanos e afro-brasileiros ficaram de fora por um longo tempo. Os nossos palcos percorreram um longo caminho para a incorporação de intérpretes brasileiros, de dramaturgias, de invenções pautadas no nosso patrimônio cultural. Esses embates persistem até hoje.

Entretanto, não entendia por que não poderia ser atriz. Estava na idade da autoconfiança. Na minha cabeça, o teatro era um espaço para a contação de quaisquer histórias. Sonhava em interpretar quaisquer personagens, sem distinção. Mas não recebi conselhos animadores. Ouvi, inclusive, que, se eu insistisse, ficaria restrita aos papéis subalternos pouco desenvolvidos e às personagens do período da escravidão apresentadas nas poucas produções a abordar essa temática. Além disso, no meu bairro, não havia teatros. Em minha opinião, segundo o governo vigente, o teatro parecia não ser uma necessidade da gente da periferia onde eu morava. Talvez fosse exclusivo da chique zona sul, mais favorecida geográfica e economicamente. Interessante observar que, quase trinta anos depois, ainda não foi construído nenhum teatro no meu bairro da infância, nem cinema, nem espaço cultural.

\footnotetext{
${ }^{5} \mathrm{O}$ termo foi utilizado pela primeira vez em 1922 por um jornalista americano, Walter Lippmann, em um estudo sobre opinião pública. O autor tomou-o emprestado das técnicas de impressão tipográfica e sua origem se encontra nas expressões gregas: stereos, que significa sólido, e tupos, que significa impresso - "Uma placa de impressão colada a um molde. Como essa placa é feita de metal, é difícil, uma vez moldada, mudá-la. Cada vez que ela imprime, produz a mesma impressão, a mesma imagem”. Estereótipos, preconceito e discriminação racial. Disponível em:

<https://grupos.moodle.ufsc.br/pluginfile.php/1706/mod_resource/content/0/modulo4/mod4_unidade2_texto5.pd f>. Acesso em: $10 \mathrm{dez} .2015$.

${ }^{6}$ É importante assinalar que as culturas indígenas também se encontraram marginalizadas do processo de constituição do teatro brasileiro, apesar dos padres jesuítas terem utilizado largamente de elementos cênicos para a catequização dos povos brasileiros. Entretanto, não vamos aprofundar a questão, uma vez que não é foco desta dissertação.
} 
Fazendo uma leitura rápida das políticas públicas empreendidas na periferia, o acesso à cultura parecia e ainda parece desnecessário, um luxo em uma comunidade como a minha, que, assim como tantas outras, carecia de segurança, saúde, educação, entre tantas necessidades básicas.

Em casa, assistindo TV, constatei que era mesmo pequena a participação de artistas negros nos comerciais, nas novelas e em outros programas. Estávamos em algum lugar social que eu ainda não conseguia descrever, excluídos, como se não fizéssemos parte do país, exceto nos noticiários, em que aparecíamos como criminosos, desempregados e outras condições de desfavorecimento social.

A escola me ofereceu acesso a outras realidades. Além das idas à igreja e ao médico, foi o segundo deslocamento para fora do bairro. Para chegar ao colégio, pegava ônibus, já que a instituição de ensino particular onde estudava estava localizada em outro bairro - mais "nobre". Na quarta série primária, tive uma professora adorável que gostava de ensinar contando histórias com um quadro de feltro onde colava as personagens e o cenário. Ficou viva na minha memória a imagem das diversas personagens coloridas. Observando os tipos apresentados, principalmente quando ela dizia que cada um tinha seu papel na construção da sociedade, eu pensava: qual seria o meu espaço no mundo? Uma pergunta complexa, sem dúvida.

Sempre fui uma menina muito questionadora e comecei a refletir sobre como seria meu futuro, quais eram as perspectivas para a minha vida adulta. No meu bairro, observando as mulheres adultas mais próximas, percebia que muitas eram casadas com maridos que viviam de pequenos biscates, alguns alcoólatras, enquanto elas lavavam e passavam roupas para fora. Outras não tinham marido, cuidavam sozinhas dos filhos, e outras eram solteiras e cuidavam dos sobrinhos para que as irmãs trabalhassem. Poucas tinham acesso a escolaridade além do ensino fundamental. Os homens também não avançavam nos estudos.

Além disso, percebi que as mulheres negras eram as mais solitárias do bairro quer seja nos relacionamentos com homens negros assim como com brancos. As não negras eram consideradas "mais bonitas", pareciam mais felizes, mas nunca me enganei com falsas aparências. Todas, conscientes ou inconscientes, sentiam o peso do machismo e da violência, física ou simbólica, que incidia sobre os corpos femininos.

Eu ouvia com atenção as conversas das mães e tias sobre os homens. Os homens eram tão desconhecidos e temidos quanto o mundo lá fora. As mulheres não tinham tempo de lazer, estavam sempre trabalhando em casa, cuidando dos filhos, entre outras tarefas. Questionava por que a maioria delas não tentava uma vida fora dali. Por outro lado, os 
homens pareciam ora ameaçadores, ora frágeis e infantis! Assim como as crianças, não eram capazes de servir a própria comida, ou prepará-la, não sabiam cuidar das roupas que vestiam, nem tinham forças para avançar em caso de doença. Dependiam das mulheres para tudo. Egocêntricos e violentos, ou passivos, distantes e acomodados. Eram questões sem resposta naquela época.

Eu queria mais. Buscava saídas. Procurava respostas na biblioteca da minha escola, onde li as primeiras peças teatrais. Os livros nunca me apresentaram portas fechadas. Com eles descobri a possibilidade de outras construções de mundo. Aprendi a amar e conhecer um pouco da linguagem teatral, mesmo sem ter ido a nenhum espetáculo. $\mathrm{O}$ teatro sempre existiu muito além dos edifícios. Ainda que intuitivamente, o amor pelas artes cênicas, com sua magia a despertar um universo de imagens e sensações, já estava dentro de mim.

Certo dia, em casa, já com quatorze anos, lendo os jornais do dia, vício que herdei do meu pai, encontrei o anúncio de um curso profissionalizante de teatro, gratuito, oferecido pelo Serviço Nacional de Aprendizagem Comercial (Senac), ${ }^{7}$ onde concluí essa formação e nunca mais parei de atuar. Tive que romper alguns preconceitos porque meninas dessa idade não costumavam andar sozinhas, mas eu era órfã de mãe, falecida quando eu tinha sete anos. Não havendo tanto patrulhamento, consegui a autorização de um irmão mais velho e fui.

O desejo de contar histórias cenicamente e interpretar personagens foi a minha primeira ação indisciplinada no contexto dos papéis destinados a crianças negras cariocas de subúrbio. As artes da cena têm formado meu corpo há anos, respondendo a diversas inquietações desde que eu era uma menina sonhando interpretar Julieta, personagem de William Shakespeare.

Desde que fui preterida em uma peça da escola, em que eu queria fazer o papel de princesa e recebi uma vassoura da professora, informando que eu ficaria melhor no papel de "bruxa", desenvolvi uma fixação por essa personagem trágica achada em um velho livro meio sujo, doado por algum vizinho a meu pai, ávido leitor. Eu queria ser a Julieta. Tinha a ousadia das crianças. Animada por esse ímpeto, resolvi organizar, junto com alguns amigos do meu lote, uma peça teatral.

Em busca de um local para a encenação, tomei posse de um galinheiro abandonado que havia no fundo do meu quintal, improvisando um varal como cortina e usando o muro de concreto como pano de fundo da cena. Reunindo amigos, parentes e

\footnotetext{
${ }^{7}$ O Serviço Nacional de Aprendizagem Comercial (Senac) é, desde sua criação, em 1946, o principal agente da educação profissional voltado para o setor do comércio de bens, serviços e turismo. Disponível em:

<http://www.senac.br/institucional/senac.aspx>. Acesso em: 6 dez. 2015.
} 
vizinhos, formamos um coletivo teatral incerto. Eu "dirigia" os trabalhos. Conseguimos plateia graças à divulgação "no grito" pelas ruas do bairro e à participação dos vizinhos mais próximos. Na encenação improvisada, interpretei uma Julieta sem Romeu, porque o protagonista não apareceu na hora do espetáculo. Mas era Julieta sim.

Depois do teatro, vivi a euforia, a alegria das estreias. O público aplaudiu, não vaiou, riu muito e ao final ouvi comentários duvidosos sobre a ação de uma menina negra de cabelos crespos, nomeados "duros" e "ruins", e sobre a sua ousadia ao ocupar a cena como Julieta. Disseram, entre outras coisas: "Mas essa Julieta não era estrangeira?", "Não era branca?", "Ficou esquisito. Neguinha metida a besta. Essas crianças adotadas são problemáticas. Está com essas loucuras porque a mãe é branca. Mas é preta sim.”, "Uma negra nobre? Princesa? Essas crianças são loucas."

Eu chorei. Aos olhos dos outros, não poderia ser princesa, não era adequada para o papel, por quê? Não entendia como as coisas funcionavam. Não entendia as crueldades humanas. Mas queria seguir com o teatro. Meus amigos logo desistiram do grupo, procuraram outra diversão. Eu fiquei sozinha com minhas inúmeras inquietações.

Até aquela altura, não havia tido contato com personagens negras de destaque nas histórias contadas ou lidas. Desconhecia, por exemplo, que a Rainha de Sabá, muito citada na Bíblia, que li depois de adulta, mas de quem eu nunca tinha ouvido falar na igreja que frequentava com mamãe, era negra e infelizmente tivera sua imagem embranquecida para atender aos moldes predominantes.

Mas a quem interessaria a revelação do pertencimento étnico da mulher próspera, guerreira, que liderou exércitos e morou em grandiosos palácios? Ninguém jamais imaginaria uma rainha negra cuja história de vitórias tivesse sido contada na Bíblia Sagrada. Inclusive os crentes eram racistas e preconceituosos. Os crentes eram como quaisquer pessoas, eu já não tinha ilusões. Eu sabia disso porque muitos filhos dos amigos da minha mãe não gostavam de brincar comigo. Diziam que minha mãe não era minha mãe, que eu era adotada, por isso não tinha valor, e me xingavam o tempo todo, usavam apelidos depreciativos para a cor da pele, os traços e o cabelo. Para eles, eu era uma pretinha muito metidinha.

Entendi muito tempo depois que ser uma "negra metidinha" significava tentar realizar meus sonhos, mas isso caracterizaria demasiada ousadia, porque o mundo não foi construído para o êxito da população negra. A "boa negra", esperada e "acolhida" pelo sistema para ser alocada em um espaço demarcado, seria aquela que não questionaria os espaços de subalternização; pelo contrário, atuava nessa condição com prazer. Negras e negros não deviam tentar entrar no mundo dos brancos e dos "não negros". Entretanto, para 
mim, minhas escolhas eram lícitas. Eu não vislumbrava nenhuma forma de competição, não queria invadir o espaço de ninguém, só queria construir um lugar para que eu pudesse viver plenamente, como qualquer indivíduo.

O país sempre teve uma minoria "branca" no comando, concentrando o poder e a riqueza. Interessava, então, ao sistema dominante que os negros, (os pretos e pardos), maioria quantitativa, continuassem excluídos, à margem das oportunidades. Era uma questão de dominação, de controle social. Até mesmo a religião cumpria seu papel, excluindo toda manifestação de fé que não fosse dirigida ao Jesus loiro de olhos azuis construído pelo Cristianismo ocidental.

No caso bíblico, embora algumas personagens estivessem caracterizadas no contexto de países africanos como o Egito, no caso de Moisés, só para citar um dos muitos exemplos, ninguém era negro na Bíblia. Vejamos um trecho sobre a Rainha de Sabá:

Estou escura, mas sou bela, ó mulheres de Jerusalém; escura como as tendas de Quedar, bela como as cortinas de Salomão. Não fiquem me olhando assim porque sou negra; foi o sol quem me queimou a pele. Os filhos de minha mãe ficaram raivosos comigo. Puseram-me a guardar os vinhedos da minha própria vinha, porém não pude cuidar. ${ }^{8}$

Interessante observar no texto, de tempos tão remotos, a desvantagem daqueles cujo pertencimento étnico revelava uma pele escura. A Rainha de Sabá insistia em sua beleza, apesar da pele escura, condição de demérito segundo os padrões, portanto a condição de inferioridade era decorrente do seu tom de pele. No Cristianismo guiado por um Jesus a serviço do cânone europeu, quem ousaria imaginar a existência de uma rainha negra no escopo do livro sagrado?

Não é difícil deduzir que nossas mentes têm sido formadas com a crença na subalternização dos negros. Os contos de fada, a título de exemplo, como "A Bela Adormecida", "Chapeuzinho Vermelho", "Branca de Neve e os Sete Anões", considerados pérolas da literatura "universal", pertencem a outro contexto, distante do brasileiro. O problema não está necessariamente nesses textos. A questão é que não tivemos acesso a outros contos de fada, com personagens negras ou quaisquer outras que representassem a realidade nacional. Qualquer modelo único restringe as perspectivas de caracterização da subjetividade. Os padrões de referência e excelência no mundo da ficção influenciam e muito a projeção da realidade e da subjetividade.

\footnotetext{
${ }^{8}$ Cântico. Português. In: Bíblia sagrada. Nova Versão Internacional. Comissão de Tradução da Sociedade Bíblica Internacional. São Paulo: Ed. Vida, 2001, p. 891-892.
} 
Nos contos de fadas citados acima, típicos das culturas da Europa ocidental, as protagonistas, em sua maioria, são apresentadas em moldes de beleza em que as peles claras, os corpos esguios e os cabelos loiros e lisos estão hierarquizados no mais alto grau. Como vamos nos identificar do ponto de vista da representação? Por isso insisto na criação, ou mesmo na difusão de histórias que já existem de longa data, porém são desconhecidas ou pouco exploradas. As culturas africanas e indígenas possuem muitas lendas e histórias interessantes e ignoradas.

Voltando à história, provavelmente, nenhum dos espectadores devia conhecer de fato a história da tragédia de Shakespeare inspiradora da nossa encenação. Mas diante do imaginário coletivo, gerou um enorme estranhamento a minha ousadia ao interpretar a personagem Julieta e reivindicar o protagonismo da cena em uma sociedade que ainda delimitava espaços de subalternidade para os descendentes de africanos de diversas nações, trazidos ao Brasil em condição de escravização.

Não recuei diante das inúmeras dificuldades. $\mathrm{O}$ desejo de atuar sempre esteve em meu coração. Segui com obstinação. Foi longo o percurso, de portas estreitas, até que pudesse conquistar, aos dezesseis anos, uma cadeira nos bancos de uma universidade pública. A universidade não oferecia oportunidades de inserção para aqueles que queriam estudar, assim como eu, mas careciam de recursos financeiros.

Fui cavando bolsas remuneradas, oportunidades de estágio, descontos no restaurante universitário, enfim, corri na frente das dificuldades. Isso tem um lado bom, mas não posso deixar de refletir sobre o fato de que muitas vezes a luta diária era tão extenuante, tão cansativa, que levava muito pouco do corpo, mente e espírito ao espaço da sala de aula. Indescritível o cansaço de tentar entrar em um mundo que não parecia ser construído para nós, periféricos, pobres, negras e negros provenientes de famílias que não tinham, antes de nós, nenhum integrante a adentrar o seleto grupo de brasileiros a cursar o ensino superior.

Em grande parte das disciplinas do curso de Artes Cênicas da Universidade de Brasília (UnB), eu era a única estudante negra da turma. Caminhando pelos corredores da academia nos anos da minha formação, não era difícil perceber a ausência de estudantes negros no campus. Depois de muita luta e aprendizado, no ano de 1998, concluí a graduação como a primeira negra no Bacharelado em Artes Cênicas.

Essa formação foi o início de um tempo de muita pesquisa e prática teatral. Há mais de duas décadas, quando iniciei minha trajetória acadêmica, durante a qual concluí, além do Bacharelado em Interpretação Teatral, a Licenciatura em Artes Cênicas e a Especialização em Docência Superior, procuro pistas para o entendimento dos caminhos percorridos pelos 
artistas negros no teatro brasileiro, as razões da sua persistente invisibilidade e os procedimentos constituintes das manifestações cênicas negras.

Seriam esses procedimentos diferentes dos padrões do teatro branco, ocidental, de moldes eurocêntricos? Seria possível constituir uma estética negra sem trazer consigo os moldes da estética "branca” brasileira? Talvez fosse possível considerar as matrizes europeias e indígenas, que também são parte da formação do povo brasileiro, e incorporar o patrimônio cultural africano e afro-brasileiro.

Talvez seja esse um dos caminhos para a composição de uma estética cênica nacional. Cabe considerar que não se trata de afirmar uma estética "pura". Na verdade, são muitas as propostas estéticas fundamentadas na ancestralidade africana e na cultura afrobrasileira. O contato com várias culturas, no caso do Brasil, contribuiu para a formação de estéticas diferenciadas, híbridas, múltiplas.

Enxergar a estética negra através dos alvos véus do teatro brasileiro é uma das formas de produzir outros lugares de criação além do teatro branco de origem europeia e do teatro negro de matrizes africanas. Em meio às culturas que criam poéticas de resistência, reinam a invenção, os modos de fazer a partir de pontos de ruptura, paradoxos, contradições.

Nos textos teatrais que li, de Martins Penna, Artur Azevedo, França Júnior, só para citar alguns dramaturgos, considerando o período o século XIX, pude constatar que as personagens negras não estavam ausentes na maioria das peças do teatro brasileiro, mas grosso modo, ainda não tinham voz para contar suas próprias histórias, não existiam como sujeito da representação. O universo de criadores de dramaturgia brasileiros, não negros em sua maioria, calcados e formados na tradição eurocêntrica, modelo da maioria das nossas produções artísticas, não estava interessado, ou talvez nem considerasse a possibilidade de contar a história da ancestralidade negra, nem da cultura afro-brasileira. Interessava a história dos heróis, dos homens valiosos e memoráveis da perspectiva hegemônica. O negro conhecido, aquele que existia como servo, desumanizado e agredido, não seria digno de protagonizar essas criações.

Sempre tive a nítida sensação, ao ler alguns dos poucos textos da dramaturgia brasileira nos quais apareciam personagens negras, de que o negro apresentado nessas tramas só existia no contexto da escravidão. Para o êxito das concepções de superioridade do branco, seria necessário destruir os valores das culturas africanas, o seu legado, hierarquizando os povos. Diante do olhar europeu, os povos africanos e ameríndios encontravam-se nas trevas, a exemplo dos discursos defendidos nas teorias racialistas do século XIX. 
A história das civilizações negras, as mitologias africanas, o desenvolvimento tecnológico, as conquistas e descobertas protagonizadas pelos africanos foram silenciados. O imaginário colonial europeu foi construído a partir da perspectiva de uma sociedade africana fracassada, abrindo margem para o estabelecimento do preconceito racial. Se a África fosse apresentada como um continente malogrado, o povo negro herdaria essa condição de indignidade que mais tarde sustentaria, inclusive, o escravagismo. Essa concepção de subalternidade aparecia também nos palcos teatrais.

A pessoa do negro aparecia em algumas peças como figurante, ou exercendo qualquer função subalterna, irrelevante, não podendo ser considerada como personagem, posição que exige uma distensão no tempo e na ação dramática, para caracterizar-se como tal (MENDES, 1993, p. 29).

Muitos problemas, muitas questões. Quem saberia apresentar as personagens negras de forma humanizada? Que parâmetros sustentariam essa dramaturgia? Quem escreveria para os negros? Somente um negro poderia escrever para um negro? Por quê? Onde esses dramaturgos negros poderiam se formar para ir além dos moldes canônicos? Haveria diferenças entre a escrita de um dramaturgo branco e a de um dramaturgo negro? Por que a necessidade de nomear um teatro como "negro" e outro como "branco"? Esse teatro do negro seria exclusivo para o público negro? Existiria um teatro negro ou do negro? Caracterizado por quem? O que seria esse teatro negro?

Por outro lado, a pouca participação do artista negro na cena teatral não teria sido responsável pelo surgimento de núcleos negros teatrais de resistência? Não seria essa a única alternativa possível para a sobrevivência dos artistas negros, com raríssimas exceções? Algumas dessas inquietações povoaram minha cabeça durante muitos anos. Em 1998, ano da conclusão do Bacharelado em Interpretação Teatral na UnB, resolvi compartilhar as ideias, somar forças, buscar quem mais estivesse interessado em fazer teatro.

Nesse contexto nasceu a Cia de Arte Negra Cabeça Feita, em 1998, mesmo ano da estreia do espetáculo Uma boneca no lixo - com dramaturgia de minha autoria, direção e encenação de Hugo Rodas e participação do Grupo Cultural Asé-Dudú ${ }^{9}$ na percussão. A peça foi apresentada como trabalho de conclusão do curso de graduação em Interpretação Teatral

\footnotetext{
${ }^{9}$ Grupo Afro-Cultural Asé Dudú. Fundado em 6 de setembro de 1987, o grupo luta ao longo de mais de duas décadas contra a intolerância religiosa e racial e divulga as culturas africanas e afro-brasileiras com trabalhos na música, dança, capoeira, por meio de oficinas, cursos e outras atividades culturais. Disponível em: <http://asedudu.blogspot.com.br/>. Acesso em: 10 mar. 2016.
} 
na UnB. Segui em busca de outros parceiros. Em conversa com os atores Silvia Paes ${ }^{10}$ e Edson Duavy, ${ }^{11}$ os primeiros integrantes da companhia, compartilhei meu interesse em conhecer mais sobre as manifestações afro-brasileiras no teatro, o desejo de fazer parte de um coletivo teatral protagonizado por artistas negros, centrado nas estéticas negras. Eles também tinham seus questionamentos e, acima de tudo, o desejo de fazer teatro, de ampliar o espaço de atuação profissional. Nosso objetivo apontava para o desejo de construir um coletivo de artistas e pesquisadores negros interessados no teatro brasileiro, nas suas possibilidades de criação, nas trajetórias dos artistas negros, nos seus fluxos históricos, para encontrar informações que sustentassem e contribuíssem para o entendimento da questão.

Na ocasião, pensava em criar cenicamente a partir do nosso ponto de vista, porque desde sempre, na história do país, nós, negros e negras, tivemos pouca ou nenhuma oportunidade de apresentar nossa versão. Não tínhamos sido, até então, convidados a contar nossa versão da história. Portanto, como mentora do grupo, me interessava sobremaneira a possibilidade da existência de um espaço negro de criação teatral, onde o artista negro pudesse ser historicizado cenicamente, sujeito das suas próprias criações, paradoxal, controverso, humano.

Muitas e complexas são as questões compartilhadas nesta introdução que estarão presentes no desenvolvimento dos capítulos, algumas de forma mais direta, outras como pano de fundo. Entretanto, é importante notar que o objeto de minha reflexão nesta dissertação está centrado nas questões relativas à estética teatral de artistas e grupos negros contemporâneos.

Assim, no capítulo 1, questiono os papéis relegados aos negros nos primórdios da cena teatral brasileira. De que maneira esses artistas contribuíram para o combate à exclusão? Como se caracterizam as manifestações cênicas realizadas por artistas independentes e coletivos no período posterior? Considerando o legado de Abdias do Nascimento e do Teatro Experimental do Negro, quais as contribuições desse grupo e de outras companhias negras da época para os teatros negros contemporâneos? Esse capítulo está assentado nos conceitos e problematizações de Miriam Mendes, Abdias do Nascimento e Leda Maria Martins.

No capítulo 2, reflito sobre as estéticas negras na cena teatral brasileira. Existiria de fato uma estética negra? Várias estéticas negras? Quais seriam suas características? Seria possível separar essas estéticas da política empreendida pelos grupos como forma de resistência no enfrentamento dos percalços que ameaçam sua existência?

\footnotetext{
${ }^{10}$ Silvia Paes. Atriz, professora. Multiplicadora do Teatro do Oprimido, idealizado por Augusto Boal. Atuou na Cia de Arte Negra Cabeça Feita de 1998 a 2006. Integrante do Teatro do Concreto.

${ }^{11}$ Edson Duavy. Ator, comediante, oficineiro.
} 
No capítulo 3, promovo uma reflexão sobre os caminhos da Cia de Arte Negra Cabeça Feita e sobre meu percurso como atriz e diretora. Serão apresentadas algumas das dificuldades encontradas e os achados estéticos da pesquisa.

Finalmente, será possível afirmar que existe um teatro negro? Não seriam várias as formas de produzir teatro negro, considerando a diversidade das manifestações? Mais do que buscar respostas, é certo que são inúmeros os modos de fazer teatro dos artistas negros comprometidos com o legado africano e afro-brasileiro. São questões atuais que abrem um vasto horizonte de pesquisas e campos de investigação diante do racismo, ${ }^{12}$ com seus consequentes problemas estéticos e políticos.

Com este estudo, muitas das questões sem resposta no início da caminhada foram reavaliadas, houve muito amadurecimento e aprendizado, pois de nada valeria refletir e esmiuçar a temática sem pensar e repensar meus passos e criar outras estratégias de ação para a continuidade da minha atividade teatral. Por isso, reputo como fundamental a revisão da trajetória da companhia teatral Cabeça Feita. Esse olhar sobre o passado e sobre a contemporaneidade tem o objetivo de proporcionar o encontro com outras estratégias e invenções e o abandono de muitas certezas em benefício da ampliação de horizontes. Espero, assim, alargar meus saberes e colaborar para que outros estudos e práticas possam emergir, propiciando um adensamento dos estudos sobre teatro no Brasil.

\footnotetext{
${ }^{12} \mathrm{O}$ racismo é um conjunto de estereótipos, preconceitos e discriminações que se baseia na crença da superioridade/inferioridade de um grupo racial ou étnico com relação a outro, em uma conjuntura de dominância social. JESUS, Jaqueline de; CARVALHO, Paulo de. DIOGO, Rosália; GRANJO, Paulo. O que é racismo. Lisboa: Escolar Editora, 2014.
} 


\section{CAPÍTULO I - O NEGRO NO TEATRO}

Como confrontar estigmas, falar de racismo e discriminação em um país onde alguns setores da sociedade ainda não admitem a existência deste fenômeno? A temática tem sido discutida amplamente nos nossos dias. Impossível negar que há uma batalha em curso, envolvendo as elites e parcelas excluídas da população. A história da formação do nosso país confirma a existência de paradoxos raciais constituídos a partir "do preconceito de ter preconceito". O racismo é estruturante e extremamente complexo. O racismo não dorme. Não se trata apenas de maniqueísmos no embate entre o "negro" e o "branco". Não vivemos em um país birracial. Vários grupos étnicos fizeram parte da formação do Brasil. Nas palavras do sociólogo Florestan Fernandes (1972):

Sem a ideia de que o "negro" seria "inferior" e necessariamente "subordinado" ao "branco", a escravidão não seria possível num país cristão. Tomaram-se estas noções para dar fundamento à escravidão e para alimentar outra racionalização corrente, segundo a qual o próprio negro seria "beneficiado" pela escravidão, mas sem aceitar-se a moral da relação que estabelecia entre o senhor e o escravo. Por isso, surgiu no Brasil uma espécie de preconceito reativo: o preconceito contra o preconceito de ter preconceito. Ao que parece, entendia-se que ter preconceito seria degradante e o esforço maior passou a ser o de combater a ideia de que existiria preconceito no Brasil, sem se fazer nada no sentido de melhorar a situação do negro e de acabar com as misérias inerentes ao seu destino humano na sociedade brasileira (FERNANDES, 1972, p. 168-169).

A negação do preconceito bloqueia os caminhos para a mudança, para o estabelecimento de relações raciais mais harmônicas, pois o prejulgamento persiste incrustado nos silêncios que invisibilizam e dificultam o debate sobre as diferenças, entravando sobremaneira a criação de estéticas negras nos palcos e sua permanência, a fim de proporcionar aos intérpretes e criadores negros o aprimoramento no ofício, fundamental para a criação de oportunidades de inserção no mercado artístico.

O racismo envolve muitas questões. O processo de desumanização promovido pelo escravagismo interferiu sobremaneira na coisificação dos indivíduos, na dificuldade de visibilizar identidades oprimidas. Fato é que existem muitas maneiras de denominar um indivíduo negro. Mas a que se referem exatamente as expressões "negro", "afro-brasileiro"? Considero importante essa reflexão, pois os termos serão utilizados muitas vezes ao longo deste trabalho. Palavras não são inocentes. Carregam sentidos. A palavra abre um universo de questões semânticas, pois porta um peso negativo que não gera empatia, um temor incrustado 
no senso comum. Entretanto, mais que responder, sugiro um olhar mais atento ao conceito, suas complexidades, aspectos subjetivos e objetivos, constituídos nas relações sociais.

Para Nelson Inocêncio da Silva (2014, p. 7), “a utilização de conceitos como 'afro-brasileiro', 'negro' e ‘afrodescendente’ não significa simplesmente alusão a concepções afins, embora se saiba das vinculações estabelecidas entre elas e de seus usos mais assíduos, os quais as tornam inevitavelmente mais próximas". Essas palavras não traduzem apenas sinônimos, em virtude do seu sentido histórico, político e social. Como traduzir a experiência de negros e negras, as vivências, as tradições dos povos de um continente com cinquenta e quatro países em uma única palavra? Silva (2014) oferece informações ainda mais precisas para a compreensão da questão:

Certamente o termo "negro" é uma das mais conhecidas concepções ocidentais de que se tem notícia para distinguir africanos de europeus. Obviamente que tal designação não servia apenas para diferenciar, mas também para estabelecer hierarquias (gradações) que deixaram os povos europeus em condição vantajosa em relação aos povos africanos. Pode-se dizer que "negro" é um produto do pensamento dos colonizadores assim como "índio" também o é, pois tanto em África quanto nas Américas os povos originais se conheciam e se distinguiam entre si a partir de suas particularidades como grupos étnicos (SILVA, 2014, p. 8).

O negro, portanto, essa invenção europeia, no contexto do escravismo, não foi criado para existir como indivíduo, sujeito de direitos, cidadão, muito menos como grupo com mesma identidade étnica. Quanto mais alijado de seus valores culturais, mais enfraquecido e desorganizado em benefício do sistema colonial. No entanto, os negros e as negras, na contramão das adversidades, souberam reinventar o termo e politizar a discussão. Assim, em busca do direito de falar de si, a partir dos seus pontos de vista, a militância tem empreendido suas ações.

Para Maria Salete Joaquim (2001):

Uma das manifestações de identidade social é a identidade étnica, que permite apreender a própria etnicidade e constitui a principal característica do grupo étnico. [...] O principal significado emocional de pertinência a um grupo étnico é um princípio organizador e mobilizador de interesse de grupos específicos, com isto podendo possuir uma conotação positiva. Grupos étnicos são grupos cujos membros possuem uma identidade distinta e atribuída e, ao mesmo tempo, têm, basicamente, cultura, origem e história comuns (JOAQUIM, 2001, p. 52). 
Mas como afirmar espaços étnico-culturais negros em uma nação onde muitos cidadãos ainda não haviam se pensado como negros? Enfrentando as contradições, as manifestações culturais negras nunca deixaram de existir. Mesmo com todas as tentativas de silenciamento, a resistência sempre esteve presente nos movimentos sociais, nos becos, nas favelas, no fundo dos quintais, nas ruas e até mesmo nas igrejas, onde não eram bem-vindas. Segundo Maria da Consolação André (2008):

A temática da negritude é muito complexa, pois envolve tanto aspectos subjetivos quanto objetivos; dos primeiros temos a referência pessoal, dada pela história de cada um e, dos segundos a referência para as relações na sociedade conforme a história de cada um. A complexidade da negritude assim o é pelo fato de que tanto os aspectos subjetivos quanto os objetivos estão presentes nesta construção e que esta necessita de um processo de aprendizado sobre a história do grupo e da sociedade contextualizadamente, englobando os aspectos objetivos e subjetivos que farão a composição das identidades e das subjetivações dos diferentes sujeitos dos processos (ANDRÉ, 2008, p. 59).

Afirmar a existência de artistas independentes e coletivos teatrais formados por artistas negros é uma conquista. Mas o teatro não existe sem público. Seria necessário também enfrentar o desafio de conquistar um público - branco, negro e de outros grupos interessado nas questões abordadas, aberto à recepção das estéticas construídas e dos meandros éticos, estéticos e políticos criados por essas manifestações.

Ninguém poderia chamar de fáceis os caminhos da construção das identidades negras no país do mito da democracia racial. Para confirmar os paradoxos e a ilusão dessa democracia, convoco o leitor a uma leitura atenta dos dois trechos a seguir, retirados do Dicionário do Aurélio Online (2008):

Negro. 1. Cor negra. 2. Negrura. 3. Roupa muito escura. 4. Que recebe a luz e não a reflete. 5. Preto, escuro. 6. Sombrio. 7. Trigueiro. 8. Triste. 9. Infeliz, mofino. 10. Fúnebre, tétrico. 11. Nefando. 12. Aflito, apoquentado. 13. Dizse de ou indivíduo de pele muito escura. 14. Diz-se do escravo de pele escura. 15. Diz-se do tipo de letra de imprensa cujo desenho se caracteriza por traços mais grossos que o comum dos tipos, geralmente usado para pôr em destaque alguma parte do texto. 
Branco. 1 Cor branca. 2. Roupa branca. 3. Tinta branca. 4. Espaço não preenchido num impresso ou num texto escrito. 5. Pedra ou quadrado do dominó sem pinta marcada. 6. Espaço maior que o entrelinhas ordinário (em impressos). 7. Membrana externa branca do olho. 8. Clara do ovo. 9. Alburno; alvo. 10. Boletim de voto sem qualquer preenchimento. 11. Que tem a cor da neve ou do leite. 12. Descorado, pálido. 13. Que tem cãs. 14. Relativo a uma divisão da espécie humana caracterizada pela pele clara ou morena. 15. Que encerra todas as cores. 16. Que não teve prêmio, geralmente bilhete de rifa ou loteria. 17. Não rimado. 18. Que ou quem pertence a uma divisão da espécie humana caracterizada pela pele clara ou morena. ${ }^{13}$

Destaco o uso do Dicionário do Aurélio Online e não outro principalmente porque esse trecho consta no texto da personagem "a narradora" do espetáculo Uma boneca no lixo, no qual atuo e cuja dramaturgia assino, já abordado no presente trabalho. Esse trecho revela, por meio da referida personagem, a ressignificação de uma experiência vivida quando o li pela primeira vez, em que fica evidente o preconceito, o tom injurioso destinado aos negros. Sem dúvida, são alguns dos termos pejorativos impressos na nossa linguagem, um dos grandes pilares de sustentação do racismo.

Mas é fato que a expressão "negro/negra" é generalista, não dá conta da diversidade do continente africano e dos afro-brasileiros. Não seria tão simples definir o negro, não haveria um "negro", e sim um panteão de cores e significados. Nas palavras de Nelson Inocêncio da Silva (2014):

Se para os africanos de determinadas localidades fazia, e provavelmente ainda faça muito mais sentido referir-se a alguém como sendo axanti, fula, mandinga, iorubá, fon, baluba, bacongo, maconde, do que nomear-lhe negro, para os povos das Américas pré-coloniais ser maia, asteca, inca, tumi, yanomami, xavante, navarro, significava muito mais do que ser índio (SILVA, 2014, p. 8).

Se o termo "negro" foi inventado pelo colonizador, carregado de noções negativas, precisaria ser ressignificado, reinventado por meio de outros parâmetros, como um movimento de reação à dominação colonial, seguindo os passos de Aimé Césaire e de Léopold Sédar Senghor ao cunharem o termo "negritude".

Vejamos um pouco do histórico do movimento:

\footnotetext{
${ }^{13}$ Disponível em: <https://dicionariodoaurelio.com/>. Acesso em 10 ago. 2016.
} 
O termo "negritude" surgiu pela primeira vez com Aimé Césaire ${ }^{14}$, em 1935, em um artigo da revista L'Étudiant Noir, designando um movimento literário e político. Tentava expressar "o conjunto dos valores culturais do mundo negro", como disse Léopold Sédar Senghor ${ }^{15}$, e usar esses valores como base para a revalorização da humanidade contestada dos povos negro-africanos. Definia, ao mesmo tempo, portanto, uma atitude de altivez filosófica e a nervura intelectual de um movimento político de reconhecimento de um povo oprimido e que estava, ainda, sob o jugo colonial (MONGA, 2010, p. 26).

Na visão do movimento conhecido como negritude, o termo "guarda-chuva" contemplaria os povos da diáspora negra, sua história, a restauração de um imaginário e a capacidade de reinvenção em um contexto de positividade, ressaltando a ligação entre grupos discriminados e apartados pela opressão.

O movimento da negritude foi idealizado fora da África. Ele provavelmente surgiu nos Estados Unidos, passou pelas Antilhas; em seguida atingiu a Europa, chegando a França aonde adquiriu corpo e foi sistematizado. Depois, o movimento expandiu-se por toda a África negra e as Américas (inclusive o Brasil), tendo sua mensagem, assim, alcançado os negros da diáspora (DOMINGOS, 2005, p. 25).

Durante o século XX, no Brasil, as contribuições desse movimento foram incorporadas por organizações como Frente Negra Brasileira ${ }^{16}$ (SP), nos anos 1930, Teatro Experimental do Negro (RJ), nos anos 1940, e, posteriormente, Movimento Negro Unificado, ${ }^{17}$ no fim da década de 1970 . Vejamos um breve comentário sobre cada uma dessas iniciativas.

A Frente Negra Brasileira, uma das maiores entidades negras do século XX, que chegou a contar com mais de 400 integrantes, foi fundamental para a organização da

\footnotetext{
${ }^{14}$ Aimé Césaire nasceu na Martinica (1913-2008). Poeta. Professor. Considerado o pai do termo "negritude". Publicou mais de quatorze obras, compilações de poesias, peças de teatro e ensaios. Em setembro de 1934, Césaire fundou com outros estudantes antillo-guianeses e africanos Léon Gontran Damas, os senegaleses Léopold Sédar Senghor e Birago Diop, o jornal L'Étudiant noir (O Estudante Negro). É nas páginas dessa revista que aparecerá pela primeira vez o termo "Négritude". Disponível em: $<\mathrm{http}: / /$ www.geledes.com.br $>$. Acesso em: 1 fev. 2016.

${ }^{15}$ Léopold Sédar Senghor (1906-2001). Primeiro presidente do Senegal, aclamado poeta, escritor, professor e estadista. Um dos três cofundadores ou pais do movimento filosófico africano conhecido como "Negritude". Disponível em: <http://africanhistory.about.com/>. Acesso em: 1 fev. 2016.

16 "Em 16 de setembro de 1931, nascia em São Paulo uma das maiores entidades negras do século XX: a Frente Negra Brasileira. Vinha na esteira de diversas entidades que se formaram no início do século passado. Sua missão era integrar o povo afrodescendente à sociedade. Autodenominada 'órgão político e social da raça', a Frente atingiu dimensões inusitadas, chegando, inclusive, a tornar-se partido político." disponível em: <http://www.palmares.gov.br/?p=2913\&lang=en>. Acesso em: 22 fev. 2016.

${ }^{17}$ O Movimento Negro Unificado, MNUCDR (Movimento Negro Unificado Contra a Discriminação Racial) surgiu no clamor dos protestos contra a violenta morte de um jovem paulista, jogador de basquete, depois de ser violentamente agredido pela polícia e acusado de roubar frutas em uma feira livre em São Paulo. GARCIA, Januário. 25 anos 1980-2005: Movimento Negro no Brasil. Brasília: Fundação Palmares, 2006.
} 
comunidade negra paulista. Integrar os negros à sociedade era o objetivo principal do movimento. Considerando a realidade da época para os afro-brasileiros, quando mulheres negras eram o pilar das famílias, trabalhando nos serviços domésticos com salários insuficientes, com precário acesso a educação e saúde, e o desemprego crescente entre os homens, é possível vislumbrar o alcance dessa iniciativa político-social. A Frente Negra Brasileira chegou, inclusive, a se constituir como partido político.

No campo da cultura, do teatro e da política, o Teatro Experimental do Negro, fundado por Abdias do Nascimento em 1944, teve uma trajetória única e marcante. Seu surgimento se deu em meio a um cenário de ceticismo e rejeições diversas. A ideologia da companhia teatral desafiava o tom monocromático dos palcos brasileiros e os padrões de branqueamento da cena nacional. Nas propostas de Abdias, havia o desejo de romper as fronteiras teatrais por meio da criação de um movimento de cultura, educação e arte. O grupo será abordado adiante, ainda neste capítulo.

O surgimento do Movimento Negro Unificado (MNU) em 1978 não é um acontecimento isolado, assim como o caso das duas organizações acima citadas. Tal fato se dá em um momento de luta política pela articulação da democracia e encontra eco na luta dos negros estadunidenses pelos direitos civis entre os anos 1950 e 1970 e outros ativismos internacionais contra o racismo, assim como em vários movimentos de libertação e descolonização que resultaram na independência de países africanos como Angola (1974), Moçambique (1975), Cabo Verde e Guiné-Bissau (1975).

A luta política do MNU contribuiu para a valorização da presença negra na história e na cultura brasileira, o fortalecimento do pertencimento étnico, do orgulho negro e da construção da identidade negra que, uma vez forjada, poderia ser instrumento de luta pela inclusão social, cidadania e igualdade de direitos.

Com esse breve percurso e a reflexão sobre os termos "negro" e "negritude", é possível compreender um pouco das dinâmicas de construção desses sujeitos que percorreram longos caminhos para a formação de sua bagagem cultural. O conceito de "negritude" vai muito além de uma homogeneização racial. Não deve ser entendido a partir de generalizações, tendo em vista que seria inútil qualquer tentativa de reduzir experiências de nações tão diferentes, de tradições diversas, em seu percurso de múltiplas identidades. A necessidade de marcar um campo ideológico no que se refere à experiência negra no contexto dos povos da diáspora, negritude, nesse campo, é uma expressão de positivação, de afirmação dos valores, da cultura e da tradição. 
No presente trabalho, utilizarei as expressões "negro" e negra" e suas formas de adjetivação, corroborando as propostas de Léopold Senghor e dos seus colaboradores, como opção ética, estética e política.

De fato, sabemos que não há um trajeto prescrito para o reconhecimento e a descoberta individual do que é ser negro no Brasil. As identidades negras estão relacionadas ao meio, ao sistema cultural, aos aspectos históricos, econômicos, geográficos, entre outros. Nesse sentido, o encontro com os estudos de Stuart Hall (1992) foi fundamental para entender que os movimentos de identidade também permitem fortalecer a autoconfiança, o empoderamento pessoal e a autoestima.

A identidade plenamente unificada, completa, segura e coerente é uma fantasia. Ao invés disso, na medida em que os sistemas de significação e representação cultural se multiplicam, somos confrontados por uma multiplicidade desconcertante e cambiante de identidades possíveis, com cada uma das quais poderíamos nos identificar - ao menos temporariamente (HALL, 1992, p. 3).

Estou de acordo com o pensamento do autor quando afirma a inexistência de uma identidade completa. A identidade defendida no presente trabalho é formada no embate dialético entre o negro e a sociedade. Na multiplicidade de sentidos dessas relações, os negros se encontram na sua subjetividade, abrindo caminhos para a criação cênica, o exercício do ofício e o aprimoramento da prática teatral.

Nesse sentido, considero importante também a reflexão sobre a concepção de identidade defendida por Nilma Lino Gomes (2005):

A identidade não é algo inato. Ela se refere a um modo de ser no mundo e com os outros. É um fator importante na criação das redes de relações e de referências culturais dos grupos sociais. Indica traços culturais que se expressam através de práticas linguísticas, festivas, rituais, comportamentos alimentares, tradições populares e referências civilizatórias que marcam a condição humana (GOMES, 2005, p. 41).

Os dois autores estão de acordo quando afirmam a inexistência de um protocolo único para a definição da identidade. Sua construção vai além da aparência, do aspecto físico, pode ser pautada também por uma escolha política dos sujeitos, por aspectos subjetivos e objetivos, considerando a mestiçagem brasileira. A opção pela negritude traduz um compromisso dos sujeitos com o grupo a que pertencem. Finalmente, nas palavras de Kabengele Munanga (1994): 
[...] a identidade é uma realidade sempre presente em todas as sociedades humanas. Qualquer grupo humano, através do seu sistema axiológico sempre selecionou alguns aspectos pertinentes de sua cultura para definir-se em contraposição ao alheio. A definição de si (autodefinição) e a definição dos outros (identidade atribuída) têm funções conhecidas: a defesa da unidade do grupo, a proteção do território contra inimigos externos, as manipulações ideológicas por interesses econômicos, políticos, psicológicos, etc. (MUNANGA, 1994, p. 177-178).

Assim como dissecar o termo "negro" e seus paradoxos conceituais, reputo como importante a afirmação de um espaço estético e político para os negros, a incluir a contribuição destes, suas temáticas e tradições nos caminhos do teatro nacional.

Nas palavras de Dalmir Francisco (2006, p. 14), “[...] o negro, apesar de imerso em condições sócio-econômicas e políticas adversas, logrou preservar, reelaborar e sustentar sua cultura e desdobrar a herança africana [...]”. Assim é que foi possível, coletiva e individualmente falando, preservar no Brasil, não como objeto, mas como sujeito das próprias criações, sua história, tradições e memórias para a sobrevivência das manifestações culturais negras, a persistência na salvaguarda do legado africano e afro-brasileiro.

Até hoje, grupos negros de teatro politicamente engajados existem e resistem em situações de escassez parecidas, sem patrocínio de empresas privadas, sem reconhecimento por parte do poder público, sem acesso aos meios de produção. A invisibilidade desses coletivos, raramente considerados pela historiografia oficial, não poderia ser considerada um sinônimo da sua inexistência. Segundo o historiador Joel Rufino dos Santos (2014, p. 36), “A história da escravidão foi sempre a história da luta contra a escravidão. Muitos foram os atos de resistência dos artistas negros ao longo da nossa história".

Ao longo do século XX, vários artistas negros independentes, assim como diversos grupos teatrais formados por intérpretes negros, mesmo diante de um cenário de escassas condições de trabalho, podem ser destacados como símbolos de luta pela permanência, pela especificidade e qualidade da ocupação no meio teatral.

\subsection{O teatro brasileiro e os intérpretes negros nos primórdios da cena teatral nacional}

Constituir um teatro a refletir o ponto de vista da negritude diante do imperialismo estético que considera a brancura como um cânone absoluto exige um entendimento multidisciplinar do processo histórico brasileiro. 
Como a profissão de ator não era valorizada, os indígenas e os negros foram os primeiros atores a ocupar a cena teatral nacional. Alguns jesuítas também atuaram como intérpretes. O teatro no Brasil, desde o início do século XVI, começou com a participação de intérpretes negros e indígenas em cena, na condição de escravizados:

Embora mal reconhecido, era certo ter havido um teatro negro no Brasil desde a segunda metade do século XVI, quando, no período natalino, os escravos promoviam representações de seus autos profanos: a Congada, ou Congo, As Taieiras, o Quicumbe, os Quilombos, conhecidas danças dramáticas, de evidente aculturação africana, embora passassem por autos portugueses ou franceses da Idade Média. Mesmo o Bumba-meu-boi, cuja fonte é discutida, sofreu influência negra, visível nas personagens Mateus e Bastião, "negrinhos gozados", germe dos futuros negrinhos pitorescos das comédias de costume (MENDES, 1993, p. 48).

Certamente, os intérpretes negros levaram para a cena os legados africanos. Embora separados geograficamente, trouxeram em seus corpos o universo de sua cultura, múltipla, distinta, que não deve ser folclorizada, nem reduzida à tradição oral, ao espírito comunitário, festivo, aos rituais, às danças e aos cantos, embora esses sejam alguns dos elementos marcantes desses povos.

No Brasil do século XVI, o teatro foi utilizado como instrumento da conversão católica. Era um teatro constituído para transmitir uma mensagem, sem a autonomia de temas e propostas estéticas. Os séculos seguintes - XVII e XVIII - foram marcados por inexpressiva atividade teatral, devido a várias situações, como as condições sociais do país, com o povoamento dos centros e o consequente afastamento do teatro catequético jesuítico. Além disso, foram vários os enfrentamentos com os invasores da França e da Holanda, nublando os horizontes da atividade artística.

Finda a campanha evangélica jesuíta, em se tratando da participação dos artistas negros nesse período, é importante destacar que:

No decorrer do século XVII não há referências sobre manifestações ou influências de negros escravos no que existia como teatro brasileiro de então. Mesmo porque, uma verídica experiência dramática, com toques de tragédia, estava sendo vivenciada por eles nas planícies de Alagoas. Mas, da segunda metade do século XVIII, talvez mesmo antes, até os primeiros anos do século XIX, era sabido que muitas companhias já profissionalizadas possuíam elencos quase que só de negros e mulatos, escravos ou libertos, que interpretavam personagens brancas com o rosto e as mãos pintadas de branco (MENDES, 1993, p. 48). 
Os negros em cena não representavam personagens negros; pelo contrário, interpretavam personagens brancas. Pintados de branco, ocupavam a cena, porque em branco, no contexto canônico europeu, se faziam as representações do período. A profissão de ator não era valorizada na altura; pelo contrário, era considerada um desprestígio social. Miriam Mendes (1993, p. 49) confirma essa teoria, dizendo que "seria, porém, o mulato quem mais se dedicaria à profissão de ator, normalmente considerada desprezível, vergonhosa, abaixo mesmo das mais infames e criminosas".

Ainda sobre os mulatos, cabe um realce: na visão do colonizador, os mulatos foram iludidos com certa vantagem por conta da cor de pele mais clara. Existia uma hierarquização baseada nos tons de pele. O engano era defendido com a informação de que os mais claros estariam mais perto da brancura almejada e contribuiriam para a confirmação do êxito da miscigenação. De fato, tanto os negros de pele escura quanto os de pele menos escura foram discriminados. A expressão "mulato" não será defendida neste trabalho, tendo em vista a própria etimologia da palavra: o substantivo "mulato", cujo significado define os filhos do branco com o negro, compara-os aos animais nascidos dos cruzamentos entre o cavalo e o burro ou entre o jumento e a égua. Assim, seja com os indivíduos de pele clara, seja com os de pele escura, o racismo sempre deu o tom do preconceito.

Que ninguém se engane sobre a natureza das relações desiguais entre brancos e negros no período colonial, visto que nenhum negro era considerado cidadão. Os colonizadores europeus lançaram mão de inúmeras estratégias para afirmar o poder, lembrando e relembrando o caráter abissal da dominação.

Os escravizados, submetidos aos mais terríveis instrumentos de tortura, não desistiram de lutar pela liberdade, revelando a força da resistência negra em condições extremamente desfavoráveis, embora muitos desses aspectos da escravatura não tenham sido propagados pela historiografia oficial. Aquele que ainda não conquistara a cidadania na sociedade nascente também não gozaria de outro status no teatro. Destacando o caráter da participação dos negros na cena teatral, o historiador Joel Rufino dos Santos (2014) contribui para o entendimento da questão:

Os séculos 17, 18, 19 e parte do 20, no teatro, seguiram uma regra de ouro: o negro estava nele como objeto. Pescamos no mar de peças em que o negro, digamos assim, foi inocentemente sequestrado, as que escaparam à regra, mesmo sem intenção, como Calabar, de Agrário Menezes, O Demônio Familiar, de José de Alencar e outras (SANTOS, 2014, p. 20). 
Importante observar que o teatro nacional alcançou seu desenvolvimento paralelamente ao momento de maior expansão do tráfico negreiro no século XIX (MENDES, 1993, p. 11). Para entender a participação do artista negro no teatro nacional, é essencial compreender a condição social do negro no período, pois a vida do escravizado foi o principal tema das personagens criadas no período. As personagens negras, portanto, não existiam, nessa época, além da vida no cativeiro. O regime da escravidão ainda estava muito incrustado no imaginário nacional, de modo que as personagens criadas tendiam à reprodução desse contexto, de forma desumanizada, como símbolo da dominação colonial e também eram talhadas nos moldes dos clássicos portugueses.

Mesmo diante de um cenário de atribulações, é possível afirmar que os negros aqui escravizados, oriundos de várias culturas ricas em diversidade onde o cantar, o dançar e o ritualizar sempre existiram como elementos fundamentais, não deixaram de desenvolver suas manifestações artísticas em solo brasileiro, mesmo nas senzalas, nas ruas, nos quilombos, em quaisquer espaços. Entretanto, a luta por reconhecimento e respeito aos seus valores culturais ainda é necessária nos dias de hoje.

\subsection{O artista negro como objeto da representação cômica e estereotipada}

A partir da segunda metade do século XIX e início do século XX, a participação das personagens negras foi diminuindo até se tornar escassa, com exceção das comédias, em que apareciam, sobretudo, calcadas nos estereótipos reveladores dos conflitos étnicos relacionados ao negro no seu passado como escravo. Que estereótipos eram esses? Inúmeras concepções negativas associando os negros a inúmeros pejorativos. Cabe o destaque da recorrência de artistas negros interpretando personagens risíveis.

O papel do negro no palco mudou, ao longo do tempo, por conta de dois fatores, agindo concomitantemente. O primeiro, naturalmente, foi o contexto histórico; a personagem negra mudou conforme o Brasil mudou. O segundo foi a vontade do negro de subir ao palco. Ele sempre fizera drama na rua, comédias, farsas, pastiches, desfiles, performances, etc., desde os autos jesuíticos, em que encarnaria diabos e caricaturas do homem, até criar as formas híbridas de folguedos, como é o exemplo o João do Mato, de Minas, a festa da Penha, do Rio de Janeiro, os Pontões de Pombal, da Paraíba brincadeiras e autos em que fosse hegemônico. Assim, no palco dos três séculos e meio de escravidão, o negro foi nada mais que objeto falante, podendo ser, com algumas exceções, substituído por um móvel, uma menção, uma voz, uma passada rápida no fundo do palco (SANTOS, 2014, p. 13). 
A pesquisadora Miriam Mendes (1993, p. 26-29) vai mais fundo ao afirmar que a dramaturgia brasileira do período de 1890 a 1910, no que se refere à caracterização das personagens negras, praticamente não se afastou de quatro modelos específicos nas poucas vezes em que se ocupou deles:

- Os velhos "Pai João" em total exercício da subalternidade, sem desafiar o limite imposto pelos patrões, ignorantes, reforçando as hipóteses da falta de inteligência dos negros;

- As bondosas e amorosas "mães negras" e as dedicadas "mucamas", figuras apresentadas sem subjetividade, com ingênua sabedoria, cheias de afeto e doçura;

- A mulatinha cria da casa, inculta e caipira, puramente cômica, ansiosa pela liberdade fora da casa dos patrões, mas desiludida com a vida lá fora, retornando ao seio da família dos antigos colonos;

- O negro carioca (folião de carnaval, malandro, vivendo de expedientes, pouco amigo do trabalho).

Esses tipos, predestinados às comédias, ainda estão presentes em várias peças teatrais nacionais. Nelas encontramos os velhos "Pai João", como tipos simples, motoristas, porteiros, entre outras profissões, e as "mães negras", como babás, empregadas antigas das famílias mais abastadas. No caso da "mulatinha cria da casa", também podemos citar as babás e empregadas fofoqueiras e engraçadas, brejeiras e sensuais. O "negro carioca", assim como os demais tipos, ainda aparece em uma extensa galeria de personagens na história do teatro brasileiro nos dias atuais.

É importante destacar que a participação predominante dos artistas negros, sobretudo no gênero cômico, vai além de uma escolha ocasional. Segundo Patrice Pavis, no seu Dicionário de teatro (1996, p. 52), a comédia pode ser definida por três critérios opostos à tragédia: i) as personagens são de condição modesta; ii) seu desenlace é feliz; iii) a finalidade é provocar o riso no espectador.

Considerando esses três aspectos gerais da comédia, cabe observar que o riso do espectador talvez seja consequente, entre outras razões, da condição de superioridade da plateia diante de personagens desumanizadas e imbecilizadas nas tramas. Nesses casos, o modelo estético exibido em cena acaba sendo influenciado pelas concepções ideológicas. Patrice Pavis, ainda no seu Dicionário de teatro (1996), chama a atenção para os problemas de dramaturgia no que se refere à articulação da estética e da ideologia: 
Examinar a articulação do mundo e da cena, ou seja, da estética, esta é, em suma, a principal tarefa da dramaturgia. Trata-se de compreender como ideias sobre os homens são enformadas, portanto, em texto e em cena. Isso requer o acompanhamento dos processos de modelização (de abstração, de estilização e de codificação) da realidade humana que desembocam num uso específico do aparelho teatral. A significação, no teatro, é sempre uma questão técnica de realização concreta a partir de materiais cênicos, formas e estruturas (PAVIS, 1996, p. 114).

Não é possível pensar em dramaturgia sem aliar a criação aos recursos técnicos para a escritura cênica. Na dramaturgia, a estética precisa realizar esse trabalho refinado de criar uma reflexão sobre o mundo que caiba no mundo da cena. Pensando sobre o caráter da presença dos artistas negros no espaço do teatro, considerando, sobretudo, alguns textos teatrais da segunda metade do século XIX e início do XX, é possível perceber de que maneira o negro escravizado ocupou a cena nacional, já que sua participação ocorreu no contexto de uma profissão muito desprestigiada no período.

Pelo número de casas de espetáculos que se tem notícia no Brasil da época, deduz-se que a burguesia e a aristocracia freqüentavam os teatros ainda que não ousassem participar das encenações. Aquilo era coisa para negros e mulheres públicas. Isto também por conta do preconceito que vinha da República (COSTA, 2004, p. 206).

A título de exemplo, vale citar Martins Pena, dramaturgo precursor do teatro de costumes no Brasil, em cuja obra o negro aparecia como alegórico, ignorante e passivo, ou ainda José de Alencar, em que a composição das personagens negras foi majoritariamente focada no escravismo e suas tragédias.

Assim também compõe suas obras Artur Azevedo, com algumas personagens negras igualmente talhadas no contexto do escravagismo. Alijados do protagonismo na cena, restavam aos negros os papéis centrados nos estereótipos cômicos, ridículos, pitorescos.

Mendes nos lembra de que (1993):

A pessoa do negro aparecia ainda em algumas peças como figurante, ou exercendo qualquer função subalterna, irrelevante, não podendo ser considerada como personagem, posição que exige uma distensão no tempo e na ação dramática, para caracterizar-se como tal (MENDES, 1993, p. 29).

Podemos dizer que, até o século XIX, o negro foi apresentado nas artes cênicas como um signo negativo, desumanizado, estereotipado. No fim do século XIX, foi decretada a Lei Áurea. No entanto, a "libertação" dos descendentes de africanos não trouxe a inclusão, a 
cidadania e o pleno gozo dos direitos e o cumprimento dos deveres.

O dia 13 de maio de $1888,{ }^{18}$ data da abolição da escravatura, não foi fruto de um ato benemérito do homem branco, assim como não melhorou a situação dos negros no Brasil, que foram abandonados à própria sorte, sem políticas públicas e submetidos a todo o preconceito herdado do legado da escravidão, desagregados no sentido familiar e sem recursos financeiros para a vida no país. Mas quais seriam as saídas possíveis diante desses paradigmas da representação teatral e da sociedade da época?

Os anos seguintes mostrarão como esses artistas reagiram a tais procedimentos discriminatórios, individualmente ou na formação dos coletivos teatrais de artistas negros. Veremos que os artistas negros retomaram o cômico em outros contextos, em um contradiscurso diante de estereótipos. A título de exemplo, em um dos meus trabalhos, uma cena curta intitulada Esperando Zumbi (2015), o texto dramático e a interpretação fazem uso do humor e da ironia e partem dos estereótipos em outra perspectiva, agora construídos a partir do ponto de vista de uma criadora negra que fala de si para todos. Nesse caso, o humor não desumaniza o negro em cena; pelo contrário, denuncia o racismo nos olhos do espectador não negro a partir da identificação com situações cotidianas de preconceito e discriminação abordadas no trabalho.

\subsection{Pequeno escol de artistas negros e companhias do início do século $\mathrm{XX}$}

No início do século $\mathrm{XX}$, vários artistas negros lutaram por espaço no meio artístico, enfrentando inúmeros desafios diante de um mercado restrito de oportunidades a todos os artistas, especialmente para os afro-brasileiros, afetados pela chaga do preconceito racial e da discriminação.

Como não existem saídas individuais, é fundamental ressaltar, ainda que de forma breve, a arte e a luta de alguns artistas e coletivos desse período, o caráter da sua participação no universo da arte e as estratégias empreendidas diante dos percalços enfrentados.

Mais que isso, é interessante observar como esses artistas tiveram suas vidas cruzadas, impulsionando uns aos outros, os primeiros servindo de referência para os demais, os descendentes almejando e concretizando futuras parcerias de trabalho, somando forças diante da hegemonia eurocêntrica.

\footnotetext{
${ }^{18}$ Data da Abolição da Escravatura. Promulgação da Lei no 3.353 , de 13 de maio de 1888.
} 
A maioria deles não conseguiu vencer o racismo e a exclusão do mercado artístico e morreu no ostracismo, desconhecida do grande público até hoje, compartilhando a invisibilidade das suas ações no campo da arte. Diante do ceticismo que não valoriza produções que não atendam aos moldes canônicos do bom e do belo no campo das artes cênicas, a quem interessaria divulgá-los? Justamente por isso, reputa-se como essencial o destaque das suas trajetórias nesta pesquisa.

\section{a) Benjamin de Oliveira (1870-1954)}

Quando comecei a pesquisar as estéticas negras, percebi que a maioria das pessoas desconhecia a especificidade dessas manifestações cênicas, porém o nome de Benjamin de Oliveira foi citado com frequência. As informações se limitavam a dizer que Benjamin foi o primeiro palhaço negro no Brasil. Eu procurava descobrir mais sobre essa personagem desconhecida de nossa história. Algo me dizia que eu encontraria mais do que o enredo romântico sobre essa figura singular.

Descobri que nasceu em 1870, data próxima da "abolição" da escravatura. Comecei a pensar em como vivia um homem negro nessa época. De qualquer forma, Benjamin foi fugitivo. Sua vida parecia ter sido marcada por fugas, tentativas de escape dos lugares sociais oferecidos aos homens negros da época. Ser artista é um ato de ousadia. No caso de um artista negro, isso implica a negação dos espaços de subalternização ideologicamente construídos para esses indivíduos, ou a ocupação desses espaços mesmo no meio artístico para a sobrevivência na profissão.

No livro Circo-teatro: Benjamin de Oliveira e a teatralidade circense no Brasil, Ermínia Silva publicou o texto a seguir, escrito por Benjamin em 1940.

Teatro na porta de casa.

O Rio é muito grande e o povo quer teatro na porta de casa.

Teatro fixo poderá satisfazer uma parte, mas não todos.

Para que, de modo geral, fiquem satisfeitos é necessário que o pavilhão vá a todos os lugares, em toda a parte.

Daí a nossa instabilidade. Organizar companhia para um subúrbio apenas não resolveria de modo algum o problema de divulgação da arte cênica (SILVA, 2007, p. 9).

Após a leitura do texto, lembrei-me das minhas inquietações no início da minha trajetória, das dificuldades de viver em um bairro que não tinha acesso à cultura. Benjamin traduziu essa realidade no trecho acima e mostrou seu comprometimento político com a arte 
de rua, circense, que, em sua opinião, deveria ser oferecida a todos, inclusive aos pobres e os periféricos. Isso foi revolucionário na época e ainda é.

Cabe a menção do pioneirismo de Benjamin de Oliveira no mundo do entretenimento, seja como palhaço, ator, cantor, instrumentista, compositor ou proprietário de circo. Infelizmente, não temos muitos estudos sobre a história do circo no Brasil, sobre as famílias circenses, a metodologia de trabalho desses profissionais e a multiplicidade de sua formação.

Benjamin de Oliveira merece ser destacado na história do circo brasileiro. Talvez existissem outros palhaços, artistas negros tão talentosos como Benjamin naquela época, silenciados pelo racismo, pelas dificuldades da profissão, cuja história não foi contada pelos historiadores, formados em reproduzir o padrão único de excelência.

A vida não foi fácil para Benjamin. No discriminado universo do circo e da cultura popular, ele, que escrevia peças para que pudesse ter papéis à sua altura, também teve que ocupar a cena com o rosto pintado de branco, conforme os ditames do período, teve que produzir, encenar, atuar, administrar. Essa extenuante fusão de tarefas tem abreviado a vida e a carreira de muitos artistas negros, que chegam ao seu limite, sucumbem ao alcoolismo e outras mazelas sociais diante do alto preço do empreendedorismo solitário e aguerrido dos negros - no palco e na vida.

Benjamin teve uma vida longa. Seu falecimento se deu aos oitenta e três anos, entretanto não gozou das honras que deveriam ser concedidas aos mestres, aos sábios, aos anciãos. Nosso país não tem memória e nem reverencia os mais velhos. Nem o mínimo direito dos cidadãos foi respeitado. Apesar dos esforços de alguns amigos, chegou ao fim dos seus dias sem direito a aposentadoria por não conseguir comprovar seu tempo de trabalho. Morreu pobre, quase miserável. Lamentavelmente, a grandeza da sua história ainda é desconhecida do grande público. Em face do racismo, ainda não tinha sido inventada nenhuma rota de fuga.

\section{b) Grande Othelo (1915-1993)}

Os artistas negros que conseguiram ingressar no cenário artístico do início do século XX com certeza serviram de inspiração para os futuros aspirantes à profissão. É o caso de Grande Othelo. Cantor, compositor, comediante, ator, poeta. Quem foi Grande Othelo? Um artista genial. Qual Othelo foi construído pela historiografia oficial? Um homem invadido em sua privacidade. 
Não é difícil encontrar quem conheça momentos negativamente marcantes da vida pessoal de Othelo, que com certeza também viveu momentos bons. Muitos sabem mais de suas vicissitudes, enquanto desconhecem as inúmeras diferenças entre Grande Othelo e Sebastião Bernardes de Souza Prata, seu intérprete. Sebastião não escapou, com toda a notoriedade da personagem, do fardo do homem negro, embora tenha confessado em várias entrevistas seu desejo de ser apenas um ator, não um ator negro.

É preciso ler nas entrelinhas para encontrar os percalços, as dificuldades, os anseios desta personagem. Muitas tragédias são enumeradas em sua biografia, entretanto não surgem com tanta frequência discussões sobre as consequências do racismo em sua trajetória. Em que medida o racismo e a opressão pode impactar as trajetórias individuais? Talvez o artista tenha sido maior que o cidadão diante do preconceito e da discriminação.

Não deve ter sido fácil lidar com o fato de que o negro que o mercado artístico acolheu foi aquele que deveria multiplicar-se em várias personagens, todas ignorantes, pobres, sofridas, malandras, ligadas aos estereótipos. Em nenhum dos seus trabalhos, Othelo interpretou uma personagem diferente dessas classificações. Era feio para os padrões, desengonçado. Justamente o negro que atendia às expectativas do imaginário do branco em suas concepções de subalternização. Sua aparência é oposta aos padrões hegemônicos desenhados para a figura do herói.

Depois de anos guardado em seu apartamento, seu acervo só foi tratado e catalogado em 2004, pela Fundação Nacional de Artes (Funarte). O público teve acesso ao material em 2008. Esse tratamento seria digno daquele que sempre foi considerado pela grande mídia como um dos maiores artistas brasileiros?

Othelo, com seu talento, conseguiu alavancar sua carreira. Mas é interessante confrontar o paradoxo de que essa ocupação do artista acaba por reforçar estereótipos ao mesmo tempo em que abre caminhos para a representação de artistas negros. Caminhos que devem ser questionados ainda nos dias de hoje em função da diminuta participação de artistas negros em produções cinematográficas, teatrais e televisivas. Com algumas exceções, ainda invade as nossas telas e palcos uma lista de personagens desumanizadas, subalternizadas e sem subjetividade.

Os papéis representados por Othelo revelam o quão reducionistas eram as personagens no que se refere à representação dos negros. Entretanto, esse artista de inúmeras habilidades conseguiu êxito em diversas áreas nas quais muitos artistas, negros e brancos, jamais adentraram. Viveu no mundo dos brancos, conviveu com eles, aprendeu a criar estratégias de resistência e permanência na profissão. Sua aparência, de estatura pequena, 
frágil, corroborava o imaginário do branco que explorou ao máximo a imagem do negro vitimizado, que gerava pena. Não tinha o porte do negro forte, alto, valente, reprodutor e ameaçador, rechaçado como ameaça ao sistema.

Segundo Roberto Moura, em seu livro Grande Othelo - um artista genial:

Um homem progressivamente refinado a quem não é dada a palavra. O negro possível desde a era Vargas, que queria mais, muito mais para sua gente e sua arte. Uma pessoa com uma extraordinária capacidade de ternura que se esconde sob certa ironia e verve - como o definiu Vinícius de Moraes (MOURA, 1996, p. 144-145).

No fim dos anos 1980, participou da Escolinha do Professor Raimundo, programa da Rede Globo liderado por Chico Anísio, em que Othelo, já no fim da vida, fazia o papel de um negro ignorante, que não dominava o português. Isso demonstra que o tempo não foi suficiente para trazer mudanças aos estereótipos que encarnou durante toda uma vida.

\section{c) Companhia Negra de Revistas - 1926-1927}

Segundo João Roberto Faria (2012, p. 437), “foi no início da década de 1920 que o Teatro de Revista encontrou e divulgou sua fórmula tipicamente brasileira, com música, dança e crítica social, já que, anteriormente, seguia os moldes das revistas francesas e portuguesas". Deu-se aí a fusão entre a música e o teatro em um período em que o país procurava descobrir seus próprios moldes para o teatro musicado.

Sobre a participação dos artistas negros nas revistas, o mesmo autor informa que, “em 1920, já havia coristas negras no teatro de revista. O Teatro São José apresentava dez coristas negras conhecidas como the black girls ao lado de outras trinta e seis brancas" (FARIA, 2012, p. 448). No fim dos anos 1920, o teatro do gênero "revista" era uma das formas de entretenimento das mais populares nas principais cidades brasileiras, sobretudo no Rio de Janeiro. Entretanto, o período continuou marcado pela prática do blackface, ressaltando as personagens negras com grosseiras características, lamentavelmente utilizadas até os dias de hoje.

No período, a cultura negra, tida como exótica, fazia grande sucesso em Paris, onde os produtos culturais africanos juntavam-se ao jazz, com músicos, cantores e vedetes norte-americanos engrossando os elencos de shows e revistas musicais. O maior exemplo dessa geração foi a americana Josephine Baker que, aos dezenove anos, estreou na Revue Négre em Paris (FARIAS, 2012, p. 448). 
A Revue Négre, de Paris, e a Revista Ba-Ta-Clan foram inspirações para a criação da Companhia Negra de Revistas, fundada pelo baiano De Chocolat e por Jaime Silva, único branco da companhia. O período da fundação do grupo foi marcado por acontecimentos como as eleições presidenciais, a Semana de Arte Moderna, ${ }^{19}$ inúmeras inovações tecnológicas que influenciaram e foram incorporadas pelas produções da companhia.

A revista, como gênero, contava com música, dança, rebolado, crítica social e política. Uma revista com atores negros era algo inédito na época e provocou muitos comentários que reforçam a situação de racismo enfrentada pela equipe:

\begin{abstract}
Espetáculo "Tudo Preto"
Cobrindo a fachada de um edifício em plena Avenida, os meus olhos divisaram um grande cartaz com o dístico: Tudo preto... Depois de fixá-lo demoradamente, entrei a conjecturar coisas, cada qual a mais negra. Apesar da tenaz campanha do mestre Teixeira Mendes para o país viver às claras, sob o lema do positivismo, a nação usa os óculos escuros do pessimismo e vê tudo preto... Por isso boquejamos às esquinas, desancamos a política, abancados em volta às mesas dos cafés, e, como estamos convencidos de que não resta aos donos disto tudo uma pitada de bom senso, acabamos vendo as coisas pretas (POOPE, 1926, p. 35).
\end{abstract}

Nesse trecho de Mário Poope, um dos colaboradores da Revista Fon Fon ${ }^{20}$, Revista ilustrada semanal fundada por Jorge Schmidt no Rio de Janeiro em 13 de abril de 1907, e extinta em agosto de 1958, o racismo, o preconceito e a discriminação estão aí para quem quiser ver. Mais adiante, no mesmo texto, outro trecho ainda mais contundente:

Seria então nada. Descobri que se tratava de coisa mais gaiata. E, para ver tudo preto, não me foi necessário usar óculos escuros... Fui direito ao guichê do teatro e, trocando um papelucho por outro, conquistei uma cadeira no recinto. Depois compreendi o letreiro do cartaz, ou melhor, não entendi coisa alguma... Tratava-se de uma companhia de revistas, uma companhia de negros autênticos, que haviam desertado do nosso serviço doméstico para o palco da Avenida (POOPE, 1926, p. 35).

\footnotetext{
${ }^{19}$ A Semana de Arte Moderna de 22, realizada entre 11 e 18 de fevereiro de 1922, no Teatro Municipal de São Paulo, contou com a participação de escritores, artistas plásticos, arquitetos e músicos. O objetivo do evento era renovar o ambiente artístico e cultural da cidade. Os artistas defendiam a livre criação e a incorporação de outras formas de expressão do "estrangeiro", não para copiá-las, mas para recriá-las de maneira própria. Disponível em: <http://www.pucsp.br/derdic/downloads/semana-de-arte-moderna.pdf〉. Acesso em: 5 fev. 2016.

${ }^{20} \mathrm{O}$ repertório temático de Fon Fon incluía os costumes e o cotidiano carioca; crítica de arte, teatral e cinematográfica; literatura, partituras, cinema, atualidades; sátira política, crônica social; jogos, charadas, curiosidades; concursos e colunismo social. Trazia flagrantes em fotos de nomes do jet set carioca, políticos, artistas e jornalistas brasileiros e internacionais. Disponível em: <http://cpdoc.fgv.br/sites/default/files/verbetes/primeira-republica/FON\%20FON.pdf>. Acesso em: 24 jul. 2016.
} 
As produções da Companhia Negra de Revista devem ser realçadas, sem dúvida, como iniciativas bem-sucedidas no tocante à qualidade artística e à estética que procurou apresentar outros lugares de representação como resposta aos estereótipos do período.

\begin{abstract}
O "teatro negro" não deixava de ser uma proposta avançada, não obstante as contradições que sempre estiveram presentes em seus espetáculos. Os avanços eram, às vezes, imperceptíveis, mas ocorriam, como ficou patente pelo estímulo que provocou no movimento dos homens negros, estes em luta contra a discriminação e o preconceito (BARROS, 2005 p. 306).
\end{abstract}

A Companhia Negra de Revista não foi um movimento isolado na produção das estéticas negras no país, sucedida pelo Teatro Folclórico Brasileiro - Brasiliana e pelo Teatro Experimental do Negro, como veremos a seguir.

\title{
d) Haroldo Costa
}

A iniciação teatral de Haroldo Costa $^{21}$ deu-se no Teatro Experimental do Negro quando atuou na peça $O$ filho pródigo, de Lúcio Cardoso. De volta ao Brasil, depois da viagem de cinco anos pelo mundo com o Teatro Folclórico Brasileiro - Brasiliana, do qual foi um dos fundadores, diretor artístico e um dos bailarinos, foi convidado por Vinícius de Moraes, ${ }^{22}$ de quem se tornou amigo em Paris, para protagonizar a peça Orfeu da Conceição.

Conheci Haroldo Costa em um evento na Fundação Cultural Palmares no ano 2000. Na ocasião, conversamos sobre teatro e o mercado para artistas negros. Ele disse que lamentava o fato de que os artistas do meu tempo tivessem os mesmos problemas que ele enfrentou e, quando eu disse que morava em Brasília, ele falou um pouco sobre a concentração dos recursos culturais na Região Sudeste, o que praticamente excluía os artistas de outras regiões das melhores oportunidades no cenário teatral.

Antes dessa conversa, assim como a grande maioria das pessoas, conhecia apenas a imagem de Haroldo Costa veiculada pela grande mídia nacional, ou seja, como comentarista de carnaval, discorrendo sobre as escolas de samba do Rio de Janeiro. Um apagamento de toda a sua história como ator e integrante de coletivos como o Teatro Experimental do Negro e o Teatro Folclórico Brasileiro - Brasiliana.

\footnotetext{
${ }^{21}$ Nascido em 1930, Haroldo Costa foi ator, escritor, produtor, diretor e sambista brasileiro. Disponível em: <http://www.haroldocosta.com.br/paginas/ator.html>. Acesso em: 10 jan. 2016.

${ }^{22}$ Vinícius de Moraes (1913-1980) - poeta, compositor, bacharel em Letras, advogado, jornalista, diplomata, crítico cinematográfico, dramaturgo. Escreveu a peça teatral Orfeu da Conceição em 1954, texto transposto à realidade das favelas cariocas, baseado no drama da mitologia grega Orfeu e Eurídice. Disponível em: <http://www.viniciusdemoraes.com.br/pt-br/obra>. Acesso em: 15 ago. 2016.
} 


\section{e) Teatro Folclórico Brasileiro - Brasiliana}

Os grupos de dança e teatro formados por artistas negros não estavam isolados. Podemos perceber aqui como se articulavam entre si, colaborando e contribuindo para o êxito das suas atividades, parceiros em prol da construção de uma estética negra no embate artístico e político.

No primitivo Café Lamas (Largo do Machado) reunia-se um outro grupo de artistas negros, oriundos do teatro experimental do Negro, tendo Wanderley Batista e Haroldo Costa como líderes, que começaram a ensaiar e promover diversos encontros na gafieira Flor do Abacate (no Catete), com o objetivo de agrupar os diversos negros da região, para não ficar nos bares à toa a noite toda; eles ensaiavam de 20 às 22 horas. Em 1949, o grupo deixou de se encontrar no Catete e passou a ensaiar nos fundos de uma loja de livros raros na Travessa do Ouvidor. Seu proprietário era Miecio Askanassy (19111981), um polonês radicado no Rio de Janeiro. Nesse período, nasceu o Teatro Folclórico Brasileiro, que mais tarde conquistou o mundo com o nome de Brasiliana (SILVA JR., 2007, p. 25).

O Teatro Folclórico Brasileiro - Brasiliana contribuiu para a divulgação das danças brasileiras no exterior, pois realizou várias temporadas na Europa. Cabe destacar, inclusive, que muitos bailarinos da companhia foram formados por Mercedes Baptista.

\section{f) Mercedes Baptista (1921-2014) $)^{23}$}

Tive a oportunidade de conhecer Mercedes Baptista na segunda edição do Fórum Nacional de Performance Negra, em que ela foi homenageada. Durante o evento, tive a honra de estar frente a frente com uma artista que incendiou certezas e adensou o ânimo no sentido de seguir adiante com as pesquisas sobre as estéticas negras na cena teatral brasileira.

Na ocasião, pude sentir sua energia, sua personalidade combativa em face das dificuldades encontradas no percurso da sua carreira artística. $\mathrm{O}$ momento da homenagem a essa grande mulher brasileira foi memorável. Ficamos dignificados com sua presença, com seu pioneirismo no corpo de bailarinos do Teatro Municipal do Rio de Janeiro, pois poucos de nós chegaram até lá. Mercedes poderia ter se contentado com o êxito pessoal, mas foi além, formando outros artistas e utilizando os conhecimentos adquiridos no ballet para a preparação

\footnotetext{
${ }^{23}$ Disponível em: <http://museuafrobrasil.org.br/pesquisa/hist\%C3\%B3ria-e-mem\%C3\%B3ria/hist\%C3\%B3riae-mem\%C3\%B3ria/2014/07/17/mercedes-baptista>. Acesso em: 28 fev. 2016.
} 
de uma coletividade. Com uma vida dedicada à arte negra, Mercedes não encontrou caminhos abertos; pelo contrário, desbravou novos horizontes de protagonismo para as mulheres negras, assim como para as artistas negras de ontem e de hoje.

Mas, afinal, quem foi Mercedes Baptista? O site do Departamento de Documentação e Arquivos do Museu Afro Brasil recebeu, em 2016, um conjunto de documentos de várias tipologias, centrados na vida de Mercedes, que, devidamente tratados, poderão ser disponibilizados ao grande público, contribuindo sobremaneira para a preservação da sua memória. A página do museu na internet apresenta um pequeno trecho da vida da bailarina negra e coreógrafa:

\begin{abstract}
Mercedes nasceu em 1921, no interior do Rio de Janeiro. É considerada a maior autoridade em dança folclórica afro-brasileira, explorando o maracatu, candomblé, jongo, frevo, capoeira, samba, cafezal, congo entre outras manifestações, ritmos e danças. Esse resgate da dança afro foi combinado com técnicas do ballet moderno, em especial da escola de Katherine Dunham (New York). Em 1945, torna-se a primeira bailarina negra a fazer parte do corpo de ballet do Teatro Municipal do Rio de Janeiro. Em 1952, funda sua própria companhia de dança: O Ballet Folclórico Mercedes Baptista. Com ele, representa o Brasil por toda América do Sul, Europa e EUA. ${ }^{24}$
\end{abstract}

Em sua trajetória, Mercedes se destacou pelo talento e pelo enfrentamento do racismo e do machismo, em um período em que já vigorava no Brasil a Lei Afonso Arinos, ${ }^{25}$ o que não impediu a continuidade das práticas racistas.

Mercedes conseguiu ingressar em um espaço restrito para os artistas negros, o corpo de ballet do Teatro Municipal do Rio de Janeiro. Também ampliou suas técnicas e adquiriu uma formação invejável em escolas internacionais de dança renomadas, o que proporcionou experiência fundamental para a construção de sua própria identidade como artista. Mas Mercedes foi além, pesquisando o candomblé e desenvolvendo uma vasta pesquisa que resultou na codificação de danças rituais, valorizando as tradições populares e a cultura afro-brasileira, imprimindo uma estética negra nas danças brasileiras.

Além do trabalho como bailarina, montou sua própria companhia, o Ballet Folclórico Mercedes Baptista, e enfrentou vários desafios para manter o grupo, por exemplo, a dificuldade de espaço para trabalho, de recursos materiais e de patrocínio. O grupo teve uma

\footnotetext{
${ }^{24}$ Disponível em: <http://www.museuafrobrasil.org.br/noticias/detalhe-noticia/2016/03/22/museu-afro-brasilorganiza-dossi\%C3\%AA-da-bailarina-mercedes-baptista>. Acesso em: 1 jul. 2016.

${ }^{25}$ A Lei Afonso Arinos (Lei no 1.390) foi sancionada pelo então presidente Getúlio Vargas, em julho de 1951, e foi o primeiro código brasileiro a incluir entre as contravenções penais a prática de atos resultantes de preconceitos de raça ou de cor.
} 
trajetória de êxitos ao realizar temporadas no país, na Europa e em outros países da América do Sul. Como coreógrafa, também fez parte do Teatro Experimental do Negro de Abdias do Nascimento, e sua passagem pelo grupo ficou marcada pelo seu indelével talento.

\section{g) Mário Gusmão (1928-1996)}

Mário Gusmão foi um dos homenageados na segunda edição do Fórum Nacional de Performance Negra. Sua imagem altiva, imponente, estampa a capa dos anais do fórum. Eu nunca tinha escutado esse nome. Sinceramente, não sabia de quem se tratava. Os anais do evento dedicaram páginas sobre esse grande artista:

Mário foi um dos maiores atores negros contemporâneos da Bahia. Participou de dezenas de peças de teatro, fez 16 filmes, novelas e seriados e espetáculos de dança. É um ícone para a população afro-baiana. Em 1958, é um dos primeiros negros que ingressaram na escola de teatro da UFBA. Ganha seguidas vezes prêmios como melhor ator do ano. Atuou em "O Dragão da Maldade contra o Santo Guerreiro", de Glauber Rocha. Um dos primeiros negros a receber o título de Cidadão de Salvador em 1984. Vai ao Festival de Lagos, na Nigéria, e findo o evento viaja pelo continente africano. Sem condições financeiras exila-se no sul do Estado. Segue com sua produção artística, mas não vence as limitações financeiras. Morre em 1996, em 20 de novembro, exatamente no dia da morte de Zumbi, o Dia da Consciência Negra no Brasil. Torna-se um herói para a comunidade negra baiana, sendo homenageado, no ano seguinte, na marcha do 20 de novembro, a militância com a sua foto e a expressão "Mário Gusmão vive" nas camisas. A escola do Olodum e uma rua recebem o seu nome, e o GECAP realiza um seminário em sua homenagem. Enfim, por sua obra e por sua história de sofrimento e grandeza, Mário Gusmão tornou-se uma das grandes expressões do mundo negro baiano no século XX (ANAIS DO II FÓRUM NACIONAL DE PERFORMANCE NEGRA, 2006, p. 23-25).

No decorrer do Fórum Nacional de Performance Negra, tive a oportunidade de conversar com um ator do Bando de Teatro Olodum, participante do grupo desde sua criação, o ator Jorge Washington. ${ }^{26} \mathrm{Na}$ ocasião, ele reforçou a contribuição de Mário Gusmão no cenário teatral negro de Salvador, afirmando que Mário foi a única referência negra na Bahia dos anos 1990. Segundo Jorge, Mário foi um dos pilares da sua formação teatral e também

\footnotetext{
${ }^{26}$ Militante do Movimento Negro, Jorge Washington começou sua carreira artística no grupo de teatro do Calabar, comunidade carente de Salvador. Em 1978, fez o IV Curso Livre de Teatro da UFBA, sob direção de Deolindo Checcucci. Esse morador da Liberdade queria aliar o teatro à militância. Quando estava prestes a desistir da carreira artística, viu num jornal que o diretor e ex-secretário estadual da Cultura, Márcio Meirelles, havia se juntado ao grupo Olodum para montar um grupo de teatro negro pautado na cultura afro. Depois disso, já com 21 anos de atuação no grupo formado por atores negros, ele era o único ator a participar de todas as montagens do grupo teatral, num total de 31. Disponível em: <http://blogdovila.blogspot.com.br/2011/10/atorjorge-washington-e-homenageado-com.html>. Acesso em: 15 mar. 2016.
} 
inspirou a criação do Bando de Teatro Olodum, em 1996, ano do falecimento de Mário.

Chamam a atenção na trajetória de Mário seus altos e baixos, um dia herói, em outro, cidadão sem reconhecimento, sem recursos materiais para prover seu sustento. $\mathrm{Na}$ caminhada de todos os artistas negros deste capítulo, encontramos muitas similaridades. Todos terminaram seus dias com lutas parecidas com as empreendidas no início da carreira, em busca de patrocínio, de espaço para o escoamento das suas produções, entristecidos pela falta de oportunidades para a continuidade de suas carreiras, desprezados e esquecidos por aqueles que achavam que eles deveriam ter optado por uma profissão mais "séria".

\subsection{Teatro Experimental do Negro - 1944-1961}

Não seria possível falar de estéticas negras no teatro brasileiro sem mencionar a trajetória e as produções de Abdias de Nascimento, homem que marcou sua época, vivendo intensamente seus noventa e seis anos como professor, poeta, teatrólogo, artista plástico, pesquisador, deputado, senador e, acima de tudo, um militante político que não hesitou em confrontar e denunciar o racismo e defender a cidadania dos afro-brasileiros.

Em site mantido pelo Instituto de Pesquisas e Estudos Afro-Brasileiros (Ipeafro), encontramos sua biografia resumida:

Nasce em Franca, SP, em 1914, o segundo filho de Dona Josina, a doceira da cidade, e Seu Bem-Bem, músico e sapateiro. Abdias cresce numa família coesa, carinhosa e organizada, porém pobre, e vai se diplomar em contabilidade pelo Atheneu Francano em 1929. Com 15 anos, alista-se no exército e vai morar na capital São Paulo. Na década dos 1930, engaja-se na Frente Negra Brasileira e luta contra a segregação racial em estabelecimentos comerciais da cidade. Prossegue na luta contra o racismo organizando o Congresso Afro-Campineiro em 1938. Funda em 1944 o Teatro Experimental do Negro, entidade que patrocina a Convenção Nacional do Negro em 1945-46. À frente do TEN, Abdias organiza o $1^{\circ}$ Congresso do Negro Brasileiro em 1950. Militante do antigo PTB, após o golpe de 1964 participa desde o exílio na formação do PDT. Já no Brasil, lidera em 1981 a criação da Secretaria do Movimento Negro do PDT. Na qualidade de primeiro deputado federal afro-brasileiro a dedicar seu mandato à luta contra o racismo (1983-87), apresenta projetos de lei definindo o racismo como crime e criando mecanismos de ação compensatória para construir a verdadeira igualdade para os negros na sociedade brasileira. Como senador da República (1991, 1996-99), continua essa linha de atuação. Também foi Professor Benemérito da Universidade do Estado de Nova York, doutor Honoris Causa pelo Estado do Rio de Janeiro e Doutor Honoris Causa pela Universidade de Brasília. ${ }^{27}$

\footnotetext{
${ }^{27}$ Disponível em: <http://www.abdias.com.br>. Acesso em: 1 out. 2015.
} 
Ações marcantes definem seu perfil ativista: sua participação na Frente Negra Brasileira, na década de 1930, assim como na Convenção Nacional do Negro em 1945-46. Nos anos 1950, organizou o $1^{\circ}$ Congresso do Negro Brasileiro. Sua atuação política rompeu fronteiras, já que Abdias foi um dos primeiros brasileiros a denunciar o racismo brasileiro em fóruns internacionais, no conturbado período da ditadura militar.

Condenado à revelia por ter resistido a agressões racistas, Abdias foi preso em 1941 e cumpriu pena na Penitenciária do Carandiru, em São Paulo. Encarcerado, resolveu criar um grupo de teatro na prisão. Determinado, apresentou a sugestão ao diretor da penitenciária, que concordou com a ideia e o autorizou a executá-la. Nasceu, então, o Teatro do Sentenciado, em que os presos, dirigidos por Abdias, criavam e encenavam os próprios textos. Foi, sem dúvida, um projeto de vanguarda para a época. Essa experiência de restrição de liberdade marcou seu destino como ator e diretor de teatro. Ali estava um homem aprisionado de fato, entretanto, mesmo fora da cadeia, um homem negro não podia escolher livremente seus papéis, romper com os lugares secularmente estabelecidos para os negros.

Na década de 1940, em Lima, Peru, após ter assistido à apresentação do espetáculo $O$ imperador Jones, peça de Eugene $\mathrm{O}^{\prime} \mathrm{Neill}^{28},{ }^{28}$ na qual um ator branco pinta-se de preto, Abdias do Nascimento atentou para o problema da representação das personagens negras no teatro brasileiro. Com o desejo de montar o texto no Brasil, Abdias procurou o autor. O dramaturgo O’Neill simpatizou com a causa negra de Abdias e cedeu gratuitamente os direitos da peça.

O senhor tem a minha autorização para encenar $O$ imperador Jones isento de qualquer direito autoral, e quero desejar ao senhor todo o sucesso que espera com o seu Teatro Experimental do Negro. Conheço perfeitamente as condições que descreve sobre o teatro brasileiro. Nós tínhamos exatamente as mesmas condições em nosso teatro antes de $O$ imperador Jones ser encenado em Nova York em 1920 - papéis de qualquer destaque eram sempre representados por atores brancos pintados de preto (isso, naturalmente, não se aplica às comédias musicadas ou vaudeville, onde uns poucos negros conseguiram grande sucesso). Depois que $O$ imperador Jones, representado primeiramente por Chales Gilpin e mais tarde por Paul Roberson, fez grande sucesso, o caminho agora estava aberto para o negro representar dramas sérios em nosso teatro. O principal impedimento agora é a falta de peças, mas creio que logo aparecerão dramaturgos negros de real mérito para suprir essa lacuna (O’NEILL apud NASCIMENTO; SEMOG, 2006, p. 131).

\footnotetext{
${ }^{28}$ Disponível em: <http://www.eoneill.com/>. Acesso em: 8 out. 2015.
} 
A montagem da peça de O’Neill, assistida por Abdias do Nascimento no Peru, fazia uso do blackface no caso da personagem negra em cena, o imperador Jones, protagonista da ação. Aos negros estavam reservados os papéis secundários. Seriam, então, os negros cidadãos de segunda classe? Abdias propôs um movimento teatral a fim de questionar situações dessa natureza nos palcos brasileiros.

Somos capazes de contar as nossas histórias! Dessa forma reagiu Abdias contra essa prática, procurando mudar uma realidade que ainda encontramos em nossos dias, mais de setenta anos depois. Ser negra, ser negro, é muito mais do que pintar a cara de preto. Não somos simulacros do branco, somos seres humanos com o direito de representação.

Diante de todos esses desafios, com o objetivo de mudar essa realidade nos palcos, Abdias decidiu criar o Teatro Experimental do Negro (TEN):

Em 1944 fundei no Rio de Janeiro o Teatro Experimental do Negro. Do grupo fundador participaram: Aguinaldo Camargo, Sebastião Rodrigues Alves, Tibério Wilson, José Herbel, Teodorico dos Santos, Arinda Serafim, Marina Gonçalves, e logo depois vieram Ruth de Souza, Claudiano Filho, Haroldo Costa, Lea Garcia, José Maria Monteiro, José Silva, e muitos outros (NASCIMENTO, 2002, p. 78).

Mas como o coletivo de artistas poderia interferir e mudar o cenário desigual? Com o grupo, Abdias e seus companheiros pretendiam criar um espaço no qual o negro pudesse representar e ser representado, como sujeito de sua própria história, longe dos estereótipos estabelecidos desde o período pós-escravidão, de forma a revelar sua subjetividade, sua cultura, suas tradições e sua história de resistência, pouco conhecida pelo público da época.

O Teatro Experimental do Negro (TEN), iniciativa de Abdias do Nascimento, nasce no Rio de Janeiro em 1944, e, conforme o seu fundador, foi criado "como instrumento de redenção e resgate dos valores negroafricanos, os quais existem oprimidos ou/e relegados a um plano inferior no contexto da chamada cultura brasileira, onde a ênfase está nos elementos de origem branco-européia" (NASCIMENTO, 1980, p. 68.).

O trecho acima revela os pressupostos da fundação do TEN nas palavras do seu fundador. Ainda, em outra obra, Abdias (1978) descreve os objetivos do grupo:

a) resgatar os valores da cultura africana preconceituosamente marginalizados à mera condição folclórica, pitoresca ou insignificante;

b) através de uma pedagogia estruturada no trabalho de arte e cultura, tentar educar a classe dominante "branca", recuperando-a da perversão 
etnocentrista de se autoconsiderar superiormente europeia, cristã, branca, latina e ocidental;

c) erradicar dos palcos brasileiros o ator branco maquilado de preto, norma tradicional quando o personagem negro exigia qualidade dramática do intérprete;

d) tornar impossível o costume de usar o ator negro em papéis grotescos ou estereotipados como moleques levando cascudos ou carregando bandejas, negras lavando roupa ou esfregando o chão, mulatinhas de requebro, domesticados Pai Joões e lacrimogêneas Mães Pretas;

e) desmascarar como inautênticas e absolutamente inúteis a pseudocientífica literatura que focalizava o negro, salvo raríssimas exceções, como um exercício esteticista ou diversionista, eram ensaios apenas acadêmicos, puramente descritivos, tratando de história, etnografia, antropologia, sociologia, psiquiatria, etc., cujos interesses estavam muito distantes dos problemas dinâmicos, que emergiam do contexto racista da nossa sociedade (NASCIMENTO, 1978, p. 29).

Abdias queria muito. Foram ambiciosos seus objetivos diante da realidade do racismo e da discriminação contra os africanos e afro-brasileiros, situação ainda não superada. Alcançar todos esses alvos significaria mudar toda uma estrutura ideológica e social, o que não ocorreu. Esses embates ainda estão em curso nos dias atuais.

Estou de acordo com Paulo Melgaço da Silva (2007), que apresenta também os objetivos do TEN a partir da sua interpretação:

O objetivo principal do TEN era a valorização social da gente afro-brasileira, lutando contra os preconceitos de raça e de cor e complexos de inferioridade, através de um amplo movimento de educação, arte e cultura. Esse trabalho teve uma abrangência tamanha, que conseguiu congregar o apoio de artistas e intelectuais brancos e negros. E foi, através dele, que se conseguiu formar e colocar no mercado diversos artistas negros, como: Ruth de Souza, Aguinaldo Camargo, Marina Gonçalves, Lea Garcia, Haroldo Costa, Claudiano Filho, José Maria Monteiro, Arinda Serafim, entre outros (SILVA JR., 2007, p. 26).

Mas quem foi Abdias? Uma figura lamentavelmente ainda desconhecida por grande parte dos brasileiros. Com sua trajetória, Abdias contribuiu para o rompimento dos determinismos que estabeleciam lugares demarcados para as mulheres e os homens negros de sua época, ocupando espaços nunca ocupados pela maioria dos afro-brasileiros. O seu pioneirismo aliou arte e política muitos antes das propostas de Augusto Boal (1931-2009), do Teatro do Oprimido e de seu método de trabalhar "os conflitos sociais usando a linguagem teatral com atores e não atores" (BOAL, 2011, p. 4), criados na década de 70 do século XX.

Interessante observar ainda que, para formar o elenco do TEN, foram arregimentados diversos grupos: pessoas das classes excluídas, moradores das favelas, 
empregadas domésticas, praticantes das religiões afro-brasileiras e cidadãos da classe operária, sem dúvida um coletivo de indivíduos que não ocupava habitualmente a cena teatral brasileira. Isso mostra que o grupo estava preocupado com a questão artística, mas também com a questão social.

Durante sua existência, o TEN produziu e encenou textos de grandes dramaturgos brasileiros e estrangeiros como: O imperador Jones e Todos os filhos de Deus têm asas, de Eugene O’Neill; O filho pródigo, de Lúcio Cardoso; A família e a festa na roça, de Martins Pena; Calígula, de Albert Camus; Rapsódia negra, de Abdias do Nascimento, entre outros. O TEN foi fundamental para o surgimento de futuros dramaturgos interessados em contar histórias com uma perspectiva diferenciada, ousando, inclusive, na composição de personagens negras no papel de heróis e heroínas, o que até então não era comum.

Abdias não trabalhou apenas no contexto do seu povo. Dialogou com a gente de teatro de sua época, apresentando sua perspectiva negra de concepção de mundo. O trabalho de qualidade que realizou no TEN conseguiu o apoio de muitos intelectuais da época, quer fossem negros ou brancos. A partir da convivência com Abdias, de quem era amigo, Nelson Rodrigues, dramaturgo brasileiro, chegou a afirmar em certa ocasião: ${ }^{29}$ "O que eu admiro em Abdias do Nascimento é a sua irredutível consciência racial. Por outras palavras: trata-se de um negro que se apresenta como tal, que não se envergonha de sê-lo e que esfrega a cor na cara de todo o mundo".

Abdias pretendia melhorar a situação do negro brasileiro no que se refere à representação da sua identidade, da cidadania, do cumprimento dos direitos humanos e da situação social dessas populações. Sua contribuição estendeu-se também à esfera política, já que cumpriu mandatos como deputado federal e senador da República.

Entre as ações do TEN, havia também uma pedagogia voltada para o povo negro, com cursos de formação política e até mesmo alfabetização na língua portuguesa com o objetivo de colocar a arte a serviço da cidadania. Com sua estética, o TEN propôs leituras e releituras de mundo. Mais que um grupo de teatro, o coletivo foi ímpar no sentido da criação de outras estéticas, outras formas de representação cultural. A questão principal estava voltada para o combate ao racismo no sentido de dizer que um país racista teria inúmeros prejuízos sociais, ou seja, o preconceito racial seria um entrave ao desenvolvimento do país.

\footnotetext{
${ }^{29}$ RODRIGUES, Nelson. Abdias, o negro autêntico. In: TEATRO EXPERIMENTAL DO NEGRO. Testemunhos. Rio de Janeiro: GRD, 1966. Disponível em:

<http://www.abdias.com.br/o_que_falam/nelson.htm>. Acesso em: 20 out. 2015.
} 
Creio que a vertente politicamente engajada do TEN tornou-se indispensável para transpor essas barreiras, mas, diante do contexto, não foi possível lograr êxito nesse aspecto. Mais que um fracasso do TEN, estamos diante de uma vitória do ideário racista e opressor dos pobres periféricos e marginalizados.

A dramaturgia do TEN não propôs inovações do ponto de vista das ferramentas de composição do texto teatral, ou seja, os textos foram escritos nos moldes das peças canônicas, entretanto a temática afro-brasileira, o racismo, a religião afro, os paradoxos da identidade negra foram debatidos pelo grupo. A maioria das montagens, realizadas no Teatro Municipal do Rio de Janeiro, não dotou o grupo de um caráter popular. Abdias conseguiu fazer um teatro negro tão bom quanto o teatro branco. As peças do TEN comprovam que atores negros podem interpretar tão bem quanto os brancos. Mas isso seria suficiente? Talvez. Considerando as condições da época, o grupo deu um grande salto, abrindo caminhos para que outras estéticas negras pudessem ser produzidas na contemporaneidade.

A título de exemplo, o personagem Emanuel, do texto Sortilégio - Mistério negro, última peça encenada pelo grupo, escrita em 1951, censurada por duas vezes, cuja estreia ocorreu no Teatro Municipal do Rio de Janeiro em 1957, é um homem negro em conflito com sua identidade, vivendo os paradoxos de ser negro no Brasil. Emanuel não é o negro idealizado, maniqueísta; pelo contrário, vive inúmeras contradições. Não é bom nem mal, é humano. Gosta de ser negro, não gosta de ser negro, é praticante das religiões de matriz africanas, discrimina seus cultos, quer ascender socialmente e acredita que precisa se distanciar de sua cultura, aderindo ao ideário do branqueamento para lograr êxito.

O título da peça Sortilégio - Mistério negro remete aos mistérios da cultura negra, demonizados pela cultura cristã. Fala também das contradições na formação religiosa de Emanuel. Evoca ainda as tradições, os rituais presentes na cultura africana, temas de várias peças encenadas pelo TEN.

Emanuel, um advogado, vive dificuldades de aceitação da sua subjetividade e atividade profissional em uma sociedade racista e preconceituosa. Traz consigo um relacionamento mal resolvido com uma mulher negra, Efigênia. Assume um compromisso afetivo com uma mulher branca, Margarida, com quem acaba por se casar. Na trilha de vários conflitos entre o casal, envolvendo inclusive questões raciais, acaba questionando a fidelidade da mulher, sente-se humilhado e sofrido e mata Margarida. Desesperado, foge para o terreiro de candomblé, buscando refúgio no universo das raízes outrora desprezadas. 
Emanuel - Exu é um só, ou é muitos? (risadas insistentes) Oh... Estou abandonado... estou perdido. Não tenho mais forças... O "coisa ruim" vai tomar conta de mim. (tira o paletó, os sapatos, as meias; levanta-se; ouve-se o ponto de Oxumaré; sorrindo). Até onde você vai parar heim, Dr. Emanuel? Se apavorando à toa como reles ignorante. Que adiantaram os anos de Universidade? Se impressionando com bugigangas. Rezando o Padre Nosso. Chamando até por Jesus Cristo. Deus de padre é feitiçaria de branco. Mas feitiçaria igualzinha a esta aqui (NASCIMENTO, 1961, p. 184).

Na peça, Abdias valoriza as religiões de matriz africana, mas não escamoteia as dificuldades e os paradoxos enfrentadas pelos seus praticantes. Emanuel é representado no contexto de uma sociedade que inferioriza os negros. Está na zona de conflito, solitário, alvo do desprezo dos brancos e dos negros. Uma personagem com muitos desdobramentos, muito convidativa pelo seu caráter múltiplo, pois permite nuances de interpretação, detalhe desejado pela maioria dos atores e atrizes.

Seriam os produtores de práticas como o blackface capazes de compreender a dimensão trágica e humanizada da personagem Emanuel? Seriam os espectadores negros capazes de se identificar com Emanuel, além dos sentimentos de culpa, enxergando-se como frutos de uma sociedade racista? No fim do texto teatral, Emanuel percebe a inutilidade de suas tentativas de branqueamento, percebe a realidade cruel do racismo e ensaia um movimento de mudança, de ressignificação da sua identidade a partir da sua conscientização:

\begin{abstract}
Emanuel - Tomem seus troços. Com estas tapeações vocês abaixam a cabeça dos negros. Arrancam o orgulho deles. Lincham os coitados por dentro. E eles ficam domesticados... castrados... mansos... bonzinhos de alma branca. Comigo se enganaram. Nada de mordaça na minha boca. Imitando vocês que nem macaco. Até hoje fingi que respeitava vocês... que acreditava em vocês. [...] Eu não podia amar uma criatura que teria a marca de tudo que me renegou. Sonhei com um filho de face escura. Escuridão de noite profunda. Olhos pretos como abismo. Cabelos duros, indomáveis. Pernas talhadas em bronze... punhos de aço para esmagar a hipocrisia do mundo branco. Brancura que nunca mais há de me oprimir, estão ouvindo? Está ouvindo, Deus do céu? Quero que todos ouçam. Venham todos, venham! (NASCIMENTO, 1961, p. 195).
\end{abstract}

Entretanto, Sortilégio parece não ter agradado às plateias brancas, assim como Anjo negro, texto de Nelson Rodrigues, não agradou. Nada fácil discutir aspectos fulcrais da cultura colonial brasileira tão pouco tempo depois do escravismo. A temática levada à cena pelo TEN continua atual e controversa, embora alguns avanços possam ser considerados a partir das propostas estéticas de alguns grupos e artistas independentes que ainda enfrentam situações de apagamento e exclusão no mercado artístico nacional. 
Anjo negro, tragédia de Nelson Rodrigues, teve sua estreia em 1948, depois de censurada por dois anos. Ismael foi representado por um ator branco pintado de negro. Com as reações da censura da época, parece ter sido a única opção para que a peça ocupasse a cena. Não houve chance para Abdias, que interpretaria Ismael. $\mathrm{O}$ amor entre uma mulher branca e um homem negro, interpretado por um ator da mesma etnia, não poderia ocupar os palcos da época. Outras questões na abordagem do autor, com ênfase no incesto, no sexo e nas relações familiares, temas fortemente destacados na obra, também geraram protestos contra o texto.

O protagonista Ismael, nome de origem cristã, assim como Emanuel, inclusive parecido com o primeiro, é um médico bem-sucedido. Também se casa com uma mulher branca, Virgínia. Ismael também quer ser outro, deseja o mundo branco, deseja ser branco. Seus filhos morrem precocemente e de maneira inexplicável.

No texto, violência, morte, desejo e loucura estão imbricados em uma trama que rompeu padrões de temporalidade e estrutura no que se refere aos textos escritos no período. No mundo de Ismael, não existe alegria nem esperança. A cor negra é um signo trágico irrevogável.

Em Abdias, percebemos o delinear de um universo mítico esboçado em preto e branco onde não existem opções para Emanuel, incapaz de espelhar-se nesse purismo, diluindo sua identidade entre os dois polos. O protagonista não consegue ser "o branco sonhado", com ideários de ascensão social, visto que jamais poderia ser branco, nem o negro autêntico, que, aliás, não acredito que exista. Emanuel quer ser aceito, faz concessões, não consegue viver em paz no mundo branco, onde não é bem-vindo. Seus dilemas repercutem nos dias de hoje, refletindo a sociedade atual, o que mostra a atualidade do texto.

O TEN, que encerrou as suas atividades em 1961, não alcançou, em seu tempo, a importância social que pretendia. Os homens e mulheres negros da época também não. Entretanto, as questões e posições defendidas por Abdias, sem dúvida alguma, abriram caminho para as produções teatrais contemporâneas com ênfase nas matrizes negras produzidas a partir do seu legado.

\subsection{O legado de três companhias de teatro formadas por artistas negros}

É impossível entender as manifestações teatrais de artistas negros engajados nos dias de hoje sem perceber a importância do legado do Teatro Experimental do Negro, de Abdias do Nascimento, no sentido de servir como referência, como fonte de inspiração para o surgimento de vários núcleos de artistas negros. Esses grupos, embora aliem a estética e a 
política como exemplos de resistência, têm constituído sua linguagem teatral por meio de caminhos cênicos diferenciados, considerando a diversidade do legado africano e afrobrasileiro, matrizes fundamentais no seu processo criativo.

\section{a) Teatro Popular Brasileiro - Solano Trindade ${ }^{30}$}

Nos anos 1950, Solano Trindade criou o Teatro Popular Brasileiro. Em finais da década de 1950 muda-se e instala o grupo na cidade de Embu das Artes (SP). Solano transformou o município em um verdadeiro centro cultural, o grupo teve êxito loca, com apresentações bastante concorridas. Com o coletivo, formado por operários, gente do povo, estudantes, Solano também percorreu vários países europeus divulgando a cultura popular, danças típicas e músicas oriundas das matrizes brasileiras e africanas.

Nas disciplinas de teatro brasileiro do curso de Artes Cênicas da UnB, nunca ouvi falar de Solano. Certo dia, em roda de conversa com escritores negros do grupo Quilombhoje $^{31}$, responsáveis pela publicação anual da antologia Cadernos Negros, da qual participo desde 2002, um poeta declamou um texto de Solano Trindade, poema cujo refrão dizia: "Tem gente com fome, tem gente com fome, tem gente com fome". Nessa ocasião fui apresentada a Solano Trindade e a partir daí busquei informações sobre o artista. Solano Trindade foi, sem dúvida, um dos precursores das estéticas negras na cultura brasileira.

\section{b) Ubirajara Fidalgo (1949-1986) - Teatro Profissional do Negro}

No site da Fundação Cultural Palmares, organismo do Ministério da Cultura responsável pela salvaguarda da cultura afro-brasileira no país, há um espaço intitulado "Personalidades Negras". Nele encontra-se, entre tantos outros, o verbete referente a Ubirajara Fidalgo:

\footnotetext{
30 Disponível em: <http://franciscosolanotrindade.blogspot.com.br/2009/02/solano-trindade-o-poeta-dopovo.html>. Acesso em: 1 nov. 2015.

${ }^{31}$ Cadernos Negros. A série tem trinta e oito anos e foi fundada em 1978 por Cuti, Abelardo Rodrigues, Hugo Ferreira Osvaldo de Camargo e Paulo Colina com o objetivo de discutir e aprofundar a experiência afrobrasileira na literatura. Atualmente o Quilombhoje, formado por Esmeralda Ribeiro e Márcio Barbosa é responsável pelas publicações anuais da antologia publicada ininterruptamente desde a sua fundação com ênfase na divulgação dos autores negros e da literatura afro-brasileira. Disponível em:

<http://www.quilombhoje.com.br/quilombhoje/historicoquilombhoje.htm>. Acesso em: 20 jul. 2016.
} 
Ator, diretor e dramaturgo, Ubirajara Fidalgo foi uma das grandes figuras emblemáticas do Movimento Negro no Brasil nas décadas de 1970 e 1980. Um dos principais articuladores do Instituto de Pesquisa e Cultura Negra (IPCN), criado em 1975 com o objetivo de combater o racismo, o preconceito e a discriminação racial. Fundador do Teatro Profissional do Negro (TEPRON), aliou a montagem de seus textos teatrais às questões relevantes relacionadas ao racismo, a discriminação no Brasil contemporâneo, o preconceito, a homofobia, a misoginia, desigualdade social e a ditadura militar. Os temas eram amplamente abordados nos debates políticos de cunho social realizados após as apresentações de suas peças. ${ }^{32}$

Até hoje, nenhum dos textos teatrais de Ubirajara Fidalgo foi publicado. Tudo que se refere à sua memória ainda não está preservado nem devidamente catalogado. Após seu falecimento, os registros de sua produção estiveram sob os cuidados de sua esposa, Alzira Fidalgo. Lamentavelmente, o silêncio tornou invisível sua produção, que poderia estar em cena em palcos do país nos dias de hoje.

Fidalgo sempre defendeu a profissionalização de atores e diretores afrodescendentes associada a uma escrita dramatúrgica própria, que retratasse a realidade da população negra e as questões a ela ligadas. "A verdadeira base para o teatro negro é o texto", dizia. O diretor também sustentava que teatro depende de bilheteria e que, para atrair o público (negro ou branco) com poder aquisitivo, eram necessárias produções de qualidade. No TEPRON, aliou a montagem de textos teatrais tradicionais a questões relevantes na abordagem do racismo e da discriminação no Brasil contemporâneo. Foi pioneiro ao levar aos palcos debates políticos de cunho social com a participação e interatividade do público, e precursor na inclusão de atores de periferias e favelas em uma companhia de teatro profissional, com oficinas e workshops profissionalizantes. ${ }^{33}$

Durante a segunda edição do Fórum Nacional de Performance Negra, tive a oportunidade de ouvir o relato de sua esposa, Alzira Fidalgo, participante do encontro, no qual expôs sua dificuldade para preservar a memória de Ubirajara Fidalgo. Segunda Alzira, embora tenha buscado várias instituições e parcerias, sempre foi tratada com indiferença, e o descaso das autoridades foi motivo de muita tristeza e revolta. Alzira persistiu na luta pela preservação e divulgação do acervo de Ubirajara Fidalgo até o fim da sua vida. Após o falecimento de Ubirajara e de Alzira, a filha, Sabrina Fidalgo, segue lutando pela preservação do acervo, ainda indisponível ao público e guardado sem o devido tratamento.

\footnotetext{
${ }^{32}$ Disponível em: <http://www.palmares.gov.br/?page_id=29767>. Acesso em: 28 nov. 2015.

${ }^{33}$ Disponível em: <http://www.funarte.gov.br/teatro/ubirajara-fidalgo-recebe-homenagem-no-teatro-de-arenasp/\#ixzz4E6konqar>. Acesso em: 2 jul. 2016.
} 


\section{CAPÍTULO II - ESTÉTICAS NEGRAS NA CENA CONTEMPORÂNEA}

Como os artistas negros poderiam produzir cenicamente diante do imperialismo da estética eurocêntrica nos palcos brasileiros? São inúteis quaisquer tentativas de assimilação, qualquer branqueamento de um artista negro para a melhor aceitação nos moldes do cânone. Esse branqueamento, seja por meio de vestimentas, trejeitos ou outros recursos, não é suficiente para transformar um ator negro em um pastiche de branco.

\subsection{O Fórum Nacional de Performance Negra}

Buscando combater as dificuldades de profissionalização dos artistas negros brasileiros, o Fórum Nacional de Performance Negra é um espaço de discussão e busca de soluções para essa e tantas outras questões ligadas às estéticas negras e à necessidade de uma política específica para o setor. O fórum pode ser traduzido como um encontro permanente entre artistas, produtores e grupos de teatro e dança negros do Brasil. $\mathrm{O}$ seu surgimento se deu a partir de um encontro de diretores negros interessados em discutir o que o teatro e a dança poderiam fazer pela Marcha Zumbi +10 .

Capitaneada por militantes negros, artistas e representações de outros movimentos sociais, a Primeira Marcha Zumbi contra o Racismo, pela Cidadania e pela Vida foi realizada no dia 20 de novembro de 1995 - a data é simbólica porque marca os 300 anos do assassinato de Zumbi, principal protagonista e líder do Quilombo dos Palmares, como um ato de indignação e denúncia diante da ausência de políticas públicas para a população negra.

Em 2005, aconteceu a Marcha Zumbi + 10, ocasião em que os militantes se manifestaram novamente, lembrando às autoridades a atualidade das reivindicações não atendidas e as novas demandas. Ainda em 2005, tornou-se público o racha no Movimento Negro, dado que as lideranças se dividiram em relação à condução do processo que culminou em uma grande manifestação pública. Em decorrência disso ocorreram duas marchas em 2005, uma no dia 16 de novembro e outra no dia vinte e dois do mesmo mês.

O ator, diretor e produtor Hilton Cobra por ocasião da realização da IV Edição do Fórum Nacional de Performance Negra afirmou que o processo da marcha foi fundamental para o surgimento do projeto do Fórum, pois durante a Marcha atentou para a necessidade política e estética de congregar os artistas e companhias negras no âmbito nacional. Mas o que é o Fórum Nacional de Performance Negra? Nos anais da primeira edição do fórum, em 2005 encontramos algumas respostas: 
Como não há saídas individuais, o I Fórum Nacional de Performance Negra é a resposta coletiva das companhias negras nas artes cênicas, pela manutenção, nos palcos, da tradição e da modernidade que constituem a experiência negra no Brasil (TEATRO BANDO DE OLODUM; CIA DOS COMUNS, 2005, p. 9).

É importante também destacar em outro trecho a fala de Hilton Cobra, um dos idealizadores do evento:

O I Fórum Nacional de Performance Negra nasce da compreensão de que é imperativo um teatro e uma dança que expressem o vigor da criação artística da população negra deste país. Sua realização é um marco no percurso histórico de movimentos significativos das artes performáticas negras brasileiras (ANAIS DO I FÓRUM NACIONAL DE PERFORMANCE NEGRA, 2006, p. 15).

Hilton Cobra reforça aqui a importância de um debate político e estético que considere não só a existência da população negra, mas que também reconheça seus saberes, seu fazer, a especificidade das suas manifestações artísticas. Mais que isso, diz que as manifestações artísticas negras são matrizes fundamentais que devem produzir e reproduzir seus contextos no âmbito do teatro, da dança e da performance. Ou seja, o fórum pergunta: a população está representada na arte brasileira? Quem representa? Como? Os negros e negras estão autorizados a falar de si? Podem criar? A quem interessam essas vozes? São perguntas legítimas para refletir sobre a necessidade de políticas públicas para o setor.

O Fórum Nacional de Performance Negra é um evento pioneiro na história da dança e dos teatros negros brasileiros. Reúne artistas independentes, representantes de grupos e de companhias de dança e teatro negros com o objetivo de fomentar o debate e a criação de uma visão compartilhada de representar nas artes cênicas, considerando o dinamismo integrador das experiências negras. Constitui-se como um espaço de discussão política e estética fundamental para a implementação de uma nova política cultural brasileira, mais descentralizadora e com um projeto de inclusão dos artistas negros radicados em todas as regiões do país. Dentre os participantes, destacam-se militantes, artistas cênicos, bailarinos, produtores, pesquisadores, teóricos, professores e estudantes de artes negros.

O evento tem como objetivo promover a troca de experiências e a discussão sobre políticas culturais para o setor. Idealizado por meio da parceria entre o Bando de Teatro Olodum (BA) e a Cia dos Comuns (RJ), o fórum tem sido realizado com recursos do Instituto do Patrimônio Histórico e Artístico Nacional (Iphan), da Secretaria de Políticas Culturais 
(SPC), da Secretaria da Identidade e Diversidade Cultural (SID), da Fundação Cultural Palmares (FCP) e da Fundação Nacional de Artes (Funarte), organismos do Ministério da Cultura.

Realizado no Teatro Vila Velha (Salvador/BA) nas quatro edições, o fórum tem promovido um amplo debate sobre as políticas públicas e seus impactos no desenvolvimento das artes cênicas negras. A programação do evento conta com atividades como: mesas de debates, palestras, oficinas, apresentações de espetáculos de dança e teatro, performances artísticas, leituras dramatizadas e lançamentos de livros.

Sua realização tem colaborado para o fortalecimento das manifestações afrobrasileiras e sua inclusão no mercado artístico, trazendo muitos frutos, como a criação dos primeiros editais para artistas negros ${ }^{34}$ da história do país promovidos pelo Ministério da Cultura (MinC) e a inclusão de artistas afro-brasileiros nas comissões de seleção dos referidos certames, até então caracterizados pela ausência desses artistas.

Vejamos como o fórum se estruturou ao longo de suas quatro edições:

\begin{tabular}{|c|c|c|c|}
\hline $\begin{array}{c}\text { FÓRUM NACIONAL DE } \\
\text { PERFORMANCE NEGRA }\end{array}$ & ANO & $\begin{array}{c}\text { GRUPOS } \\
\text { PARTICIPANTES }\end{array}$ & TEMA \\
\hline I Fórum & 2005 & 47 & Sem tema específico \\
\hline II Fórum & 2006 & 66 & $\begin{array}{c}\text { Compromisso, } \\
\text { sobrevivência } \\
\text { e política }\end{array}$ \\
\hline III Fórum & 2009 & 107 & Dramaturgia \\
\hline IV Fórum $^{35}$ & 2015 & 80 & Cultura sem racismo \\
\hline
\end{tabular}

Quadro 1 - Edições do Fórum Nacional de Performance Negra

Fonte: I, II e III Anais do Fórum Nacional de Performance Negra, 2016.

\footnotetext{
${ }^{34}$ Editais para artistas negros do Ministério da Cultura. Vários editais foram lançados desde 2012, em parceria com a Fundação Cultural Palmares, Secretaria de Cidadania e Diversidade Cultural e Secretaria Especial de Políticas de Promoção da Igualdade Racial, com o aporte inicial de mais de nove milhões de reais. Disponível em: <http://www.brasil.gov.br/@ @ search?Subject\%3Alist=Cultura\%20Negra>. Acesso em: 15 dez. 2015.

${ }^{35}$ A quarta edição havia sido prevista para novembro de 2010, entretanto não foi realizada nessa data devido ao cancelamento da verba orçamentária proveniente do Ministério da Cultura. Após os percalços, o evento foi realizado em dezembro de 2015.
} 
O IV Fórum atualizou os seus objetivos e descreve as demandas prioritárias:

O Fórum Nacional de Performance Negra é uma instância de diálogo entre grupos de dança e teatro negros de todo o Brasil, e destes com representantes do poder público federal, no sentido de criar e implementar políticas públicas para as artes negras, sobretudo no campo da performance. Desde a sua fundação, em 2005, ano em que se realizou o I Fórum Nacional de Performance Negra no Teatro Vila Velha (Salvador/BA), o Fórum tem incluído as demandas dos grupos de performance negra na agenda da política cultural brasileira, especialmente no que tange a ações concretas que favoreçam a existência e a manutenção das atividades sociais, culturais, políticas e, em especial, artísticas desenvolvidas pelos grupos (TEXTO DE ABERTURA DO IV FÓRUM NACIONAL DE PERFORMANCE NEGRA, 2015).

Hilton Cobra, um dos idealizadores do evento, em entrevista sobre o IV Fórum Nacional de Performance Negra, destacou a natureza e a importância da continuidade do projeto do grupo:

O IV Fórum parte da necessidade de continuar a discutir as políticas públicas no âmbito das artes cênicas negras, das políticas sociais da comunidade negra e do mapeamento de companhias e de grupos existentes no Brasil", explica Cobrinha, Presidente da Fundação Cultural Palmares/MinC, entre 2012 e 2014. "O IV Fórum se impõe com força e importância conquistadas nas edições anteriores. Vale ressaltar que foi por conta do Fórum que se deu início a implantação dos editais temáticos. De fato continuará abrindo espaços, buscando proporcionar reflexões cujo objetivo será a melhoria dos nossos trabalhos, o apuro técnico e a inserção no mercado de trabalho dos artistas e técnicos negros", completa Cobrinha. ${ }^{36}$

Estive presente em todas as edições do fórum com o objetivo de conhecer outros artistas negros e suas realidades e problematizações, assim como encontrar parceiros de trabalhos e compartilhar experiências. O evento revelou uma gama de manifestações, uma variedade de propostas estéticas. O contato com essa congregação de artistas contribuiu sobremaneira para o entendimento de que, embora estejamos separados geograficamente, temos problemas, interesses, perspectivas e conhecimentos comuns. O racismo ainda apresenta seus efeitos nos quatro cantos do país. Entretanto, as identidades negras não se constituem apenas a partir da dor, mas também do prazer. Do contrário o fardo seria demasiadamente pesado. Nesse sentido, foi crucial perceber que, além das dificuldades, os artistas presentes revelaram um enorme desejo de transformação por meio da reinvenção das

\footnotetext{
${ }^{36}$ IV Fórum Nacional de Performance Negra reunirá artistas de todo país em Salvador. Disponível em: $<\mathrm{http}: / /$ www.geledes.org.br/iv-forum-nacional-de-performance-negra-reunira-artistas-de-todo-pais-emsalvador/>. Acesso em: 23 fev. 2016.
} 
suas práticas para o êxito das realizações artísticas.

Reputo como importante a participação nesse evento, vital para a reflexão e a revisão da atividade da Cia de Arte Negra Cabeça Feita, pelas discussões sobre o teatro feito por artistas negros na cena contemporânea, suas proposições, pelos achados sobre a metodologia de trabalho desses artistas e a busca de estratégias para sua qualificação e profissionalização. De volta a Brasília, pude olhar para nosso grupo de teatro de fora para dentro e enxergar pontos antes invisíveis, rever práticas, esboçar soluções e abrir outros caminhos para nossas ações. A experiência comunitária é revitalizante.

A Figura 1 ilustra o quantitativo de artistas participantes e a sua localização geográfica. Essa informação revela uma realidade ampla e fértil, mostrando a expansão das estéticas e políticas negras no país.

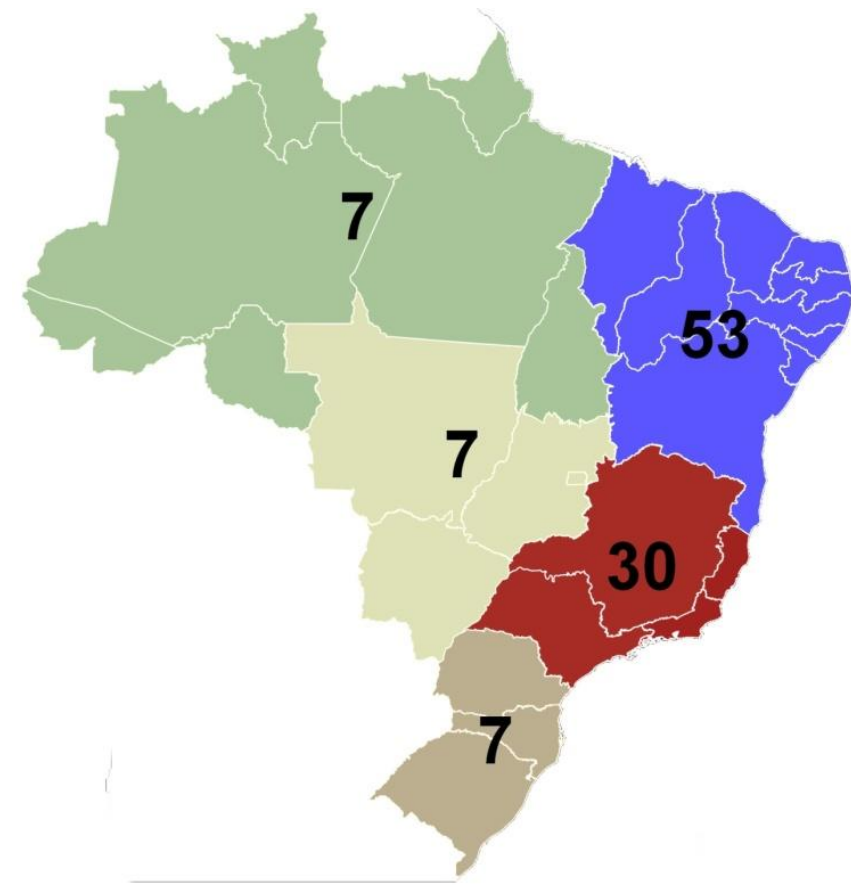

Figura 1 - Artistas que trabalham individualmente, grupos, coletivo e outros agrupamentos em todas as regiões ${ }^{37}$

\footnotetext{
${ }^{37}$ Mapa elaborado a partir das informações apresentadas nos Anais do III Fórum Nacional de Performance Negra, 2009, p. 214-230.
} 


\begin{tabular}{|c|c|c|c|c|}
\hline RegiãolGrupos & $\begin{array}{c}\text { Grupos de } \\
\text { Teatro }\end{array}$ & $\begin{array}{c}\text { Grupos de } \\
\text { Dança }\end{array}$ & $\begin{array}{c}\text { Grupos } \\
\text { Culturais }\end{array}$ & $\begin{array}{c}\text { Artistas } \\
\text { independentes }\end{array}$ \\
\hline Norte & 1 & 1 & 5 & 0 \\
\hline Nordeste & 15 & 9 & 27 & 2 \\
\hline Centro-Oeste & 2 & 1 & 2 & 2 \\
\hline Sul & 3 & 2 & 1 & 3 \\
\hline Sudeste & 7 & 4 & 16 & 8 \\
\hline Total Total de grupos pelo Brasil & & $\mathbf{1 0 4}$ \\
\hline
\end{tabular}

Quadro 2 - Distribuição de grupos e de artistas por região e atividade $^{38}$

Fonte: Autor (2016).

\section{Representantes Regionais: ${ }^{39}$}

Região Nordeste - Nivaldo Basílio

Região Sudeste - Débora Almeida

Região Norte - Telma Alencar

Região Sul - Jessé Oliveira

Região Centro-Oeste - Cristiane Sobral

É possível constatar, na Figura 1, que a maioria dos grupos e artistas independentes reside no Nordeste e no Sudeste, o que desafia as diversas pesquisas do Ministério da Cultura (MinC), que apontam para a concentração geográfica dos recursos culturais no Rio de Janeiro, São Paulo e Minas Gerais e para a escassa participação das regiões Centro-Oeste, Norte e Nordeste.

Com exceção da Bahia, os outros estados nordestinos ainda têm pouca participação de grupos culturais, de teatro, dança e artistas independentes no mercado cultural. Os estados das regiões Norte, Sul e Centro-Oeste têm um número menor de produções, mas persistentes, que vêm resistindo ao logo dos anos.

Cabe destaque para a participação de artistas independentes, concentrados em sua maioria no Sudeste, quase empatados com as regiões Nordeste e Centro-Oeste. Os grupos

\footnotetext{
${ }^{38}$ Quadro elaborado a partir das informações apresentadas dos Anais do III Fórum Nacional de Performance Negra, 2009, p. 214-230.

${ }^{39}$ Informações extraídas dos Anais do III Fórum Nacional de Performance Negra, 2009, p. 214-230.
} 
culturais de teatro e de dança existem em maior número, concentrados majoritariamente no Nordeste e no Sudeste. Os grupos de dança aparecem em menor número que os grupos de teatro em todas as regiões, com exceção do Norte, onde empatam.

A insuficiente distribuição de recursos nas regiões onde reside grande parte da população negra desse país, além de ameaçar a existência dos grupos lá constituídos, não contribui para a redução da concentração de renda e da consequente desigualdade racial e social.

Os números apresentados na Figura 1 confirmam a resistência dos artistas negros diante da exclusão racial, social e geográfica de suas manifestações culturais. Continuamos diante de um abismo social. A concentração de renda e de recursos é histórica em nosso país, desde a colonização. A exclusão social na área cultural também pode ser entendida quando comparamos o investimento do estado por região em cursos superiores de teatro e dança, assim como na construção de teatros, cinemas, museus e outros espaços culturais. É evidente que precisamos melhorar a distribuição regional, assim como criar políticas públicas para o setor, considerando ainda que as manifestações culturais criadas a partir das matrizes culturais africanas e afro-brasileiras têm necessidades específicas de avaliação, de acordo com seu caráter heterogêneo.

A cultura afro-brasileira, ao lado da indígena, é uma das principais matrizes que constituíram o Brasil, país com a maior população negra fora do continente africano (CAVALLERO, 2005). Entretanto, a maioria dos espetáculos brasileiros contemporâneos de teatro e dança ainda privilegia ideais e valores eurocêntricos. Ou seja, a arte brasileira ainda não está à altura da contribuição dos povos formadores do patrimônio cultural. A exclusão tem lugar, provoca dificuldade de profissionalização e ocorre na maioria das vezes nas localidades menos favorecidas. Nos Anais do I Fórum Nacional de Performance Negra, Rodrigues (2005) destaca a importância da discussão e do enfrentamento da centralização geográfica e social dos recursos culturais:

Descentralizar a produção, fazer circular as informações e as montagens e eventos, tornar acessivo e desejado o consumo, parecem ser os desafios das artes cênicas, já nesse contemporâneo tecnológico e ainda mais no futuro que nos acerca. E o Fórum, realizando-se pela força de dois grupos complementares, o baiano Bando de Teatro Olodum e a carioca Companhia dos Comuns, mostrou que áreas fora do "eixo cultural" podem sediar iniciativas de importância estratégica para as artes brasileiras (RODRIGUES, 2005, p. 11). 
Graças ao fórum, hoje é possível ter uma visão mais ampla de onde, em que quantidade e de que maneira estão produzindo as companhias de artistas negros neste país. Estamos conscientes de que fazemos parte de um movimento em que a política não poderia ser apartada das estéticas, para a nossa própria sobrevivência. O discurso político é um dos pilares das nossas estéticas de resistência.

O fórum permanece vivo e atuante. Sua existência "é um marco histórico de movimentos significativos das artes performáticas negras brasileiras" (ANAIS..., 2005, p. 15). O projeto resiste diante dos escassos instrumentos de fomento do Estado e dos desafios do mercado artístico. Sua existência qualifica os artistas independentes, grupos e companhias negras participantes, fortalecidos para a ampliação das discussões em todas as regiões, com o objetivo de contribuir para a promoção de políticas públicas irmanadas pela missão artística e pelo compartilhamento das dificuldades de repertório, patrocínio, pauta, divulgação, acesso ao público e aos meios de comunicação.

\subsection{Apontamentos do GT do IV Fórum Investigações Estéticas - Pistas e espaços demarcados pelos artistas negros contemporâneos}

Importa referenciar que os GTs estiveram na programação do Fórum Nacional de Performance Negra desde a primeira edição e que sempre privilegiaram ações e discussões que pudessem dar continuidade aos assuntos tratados no evento, assim como o fortalecimento de uma rede de comunicação e de trocas culturais entre os participantes.

\section{Fórum}

GT 1 - Mecanismos de comunicação e trocas entre os artistas independentes, grupos e companhias

GT 2 - Participação na Marcha Zumbi + 10

GT 3 - Manutenção dos grupos e companhias

\section{Fórum}

GT 1 - Difusão de trabalho de grupo

GT 2 - Estratégias e ações de sobrevivência 


\section{Fórum}

GT - Encontros Regionais (artistas e grupos divididos por região, discutindo estratégias de manutenção e sobrevivência das suas manifestações)

\section{Fórum}

1. PNA - Política Nacional das Artes

2. PROCULTURA (Projeto de Lei $n^{\circ} 6.722 / 2010$ )

3. Políticas de ações afirmativas - implantação do sistema de cotas raciais na cultura

4. Investigações Estéticas da Performance Negra

Interessada em integrar um grupo de discussão conectado com o tema do presente trabalho, participei do GT 4 - "Investigações Estéticas da Performance Negra". Os trabalhos do GT totalizaram oito horas divididas nos dois dias.

Artistas participantes do GT 4: total 20. Contou com representantes de quase todas as regiões, exceto a Região Norte. A região com mais integrantes foi a Sudeste. O Centro-Oeste teve apenas um representante.

\section{Centro-Oeste (01)}

Cristiane Sobral - Brasília/DF - Cia de Arte Negra Cabeça Feita - Teatro

\section{Nordeste (04)}

Amós Heber - Salvador/BA - Teatro - Artista independente

Toni Silva - Caeté-Açu/BA-Dança - Artista independente

Danielle Anatólio - Salvador/BA - Teatro - Artista independente

Edu Passos - Maceió/AL - Dança Afro - Artista independente

\section{Norte (0)}

\section{Sudeste (11)}

Débora Marçal - São Paulo/SP - Cia Capulanas - Teatro

Dirce Thomaz - São Paulo/SP - Cia Invasores - Teatro

Geo Oliveira - São Paulo/SP - Teatro - Artista independente 
Álvaro - Rio de Janeiro/RJ - Dança Afro - Artista independente

Débora Almeida - Rio de Janeiro/RJ - Teatro - Artista independente

Eliete Miranda - Rio de Janeiro/RJ - Cia Corpafro - Dança

Luiz Monteiro - Rio de Janeiro/RJ - Cia Rubens Barbô - Dança

Cridemar Aquino - Rio de Janeiro/RJ - Cia dos Comuns

Carmem Luz - Rio de Janeiro/RJ - Cia Étnica de Dança e Teatro

Grace Passô - Belo Horizonte/MG - Grupo Espanca - Teatro

Aline Vila Real - Belo Horizonte/MG - Grupo Espanca/Coletivo de Negras Autoras - Teatro

Rosana Machado - São João Del Rei/MG - TeatrIFdelRei - Teatro

\section{Sul (03)}

Iara Deodoro - Porto Alegre/RS - Grupo Afro Sul - Dança-Teatro

Daniel Amaro - Pelotas/RS - Cia Daniel Amaro - Dança

Rui Moreira - Porto Alegre/RS - Cia SeráQue? - Dança

No início dos trabalhos, o mediador, Cridemar Aquino, representante da Cia dos Comuns, deu as orientações sobre o andamento do GT. Em seguida, cada artista independente ou representante de grupo e coletivo fez uma breve apresentação do seu trabalho ou do trabalho do grupo.

Após as falas, o grupo definiu que no primeiro dia faria um debate sobre o tema do GT, com base nas experiências e nos achados estéticos de cada um no sentido de contribuir para a discussão sobre que estética negra, que linguagem cênica cada grupo estaria produzindo. Haveria traços comuns no que se refere à estética teatral negra? Haveria um teatro negro? Como poderia ser caracterizado? Foram alguns dos tópicos levantados.

Essa discussão foi considerada fundamental pelo grupo porque a defesa estética seria uma demarcação de território no sentido de fortalecer linguagens e contribuir para a criação de políticas públicas para o setor. Alguns argumentaram que não deveria haver preocupação em inserir tais definições na academia, já vez que as universidades não costumam incluir essas temáticas nos seus estudos. Mas a maioria considerou que seria de suma importância que a comunidade artística negra nomeasse suas ações, como estratégia de sobrevivência artística e intelectual, posto que em algum momento haveria estudos que não seriam necessariamente realizados por pessoas dos grupos negros ou comprometidas com nossas questões. Assim, falar de nós, dos nossos fazeres por nós mesmos, ou seja, denominar o que é teatro negro, também se coloca como uma entre tantas estratégias de resistência. 
O debate foi muito proveitoso no sentido da reflexão sobre nossas práticas. Foi um momento de pensar sobre nossas ações, sobre as intencionalidades. Começamos listando e nomeando o que cada um entendia por teatro negro, considerando a experiência como artista independente e com os grupos. Alguns dos tópicos citados na discussão foram:

- A crise de representação do teatro contemporâneo exige uma atitude dos grupos e artistas no sentido da ressignificação das invenções, pois o teatro é um lugar de criação por excelência, dessa forma, o coletivo concordou que em suas produções haveria uma tentativa de ir além do negro inventado pelas representações hegemônicas;

- Estéticas negras seriam a externação do modo negro de ser, a presença de atores negros em cena com ênfase na ancestralidade africana, na consciência negra do intérprete; essas estéticas também serias pautadas por pesquisas destinadas a investigar a expressão do corpo negro, sua memória cinestésica, na cena teatral;

- Para pensar sobre o corpo negro, não seria possível esquecer o corpo não negro, já que esse corpo negro também é uma criação do colonizador. Além desses estereótipos do escravismo, onde habita um corpo desumano, inumano, o que seria o corpo negro? O corpo é uma manifestação da consciência, não existe fora das relações com outros corpos. O corpo também se cria a partir da construção do outro, do que significa para o outro. A partir de visões distorcidas plantadas no inconsciente coletivo, o corpo negro, originário de uma África incapaz, serviu para o fortalecimento da Europa;

- Diferentemente da representação costumeira no teatro nacional, as personagens do teatro negro são criadas além dos maniqueísmos de mal e bem, têm família, complexidade, história e memória;

- No universo das temáticas para a dramaturgia, o teatro negro incluiria a referência aos mestres, o reconhecimento como guardiões da linguagem e da tradição e a consciência da importância da salvaguarda e da continuidade do legado da ancestralidade africana e afro-brasileira;

- O teatro negro, ou os teatros negros - porque os grupos não concordaram com um protocolo único para a temática, considerando as identidades múltiplas e a diversidade das suas produções - teria(m) liberdade de criação a partir do universo simbólico negro, com suas tradições, costumes, memórias, histórias e religião;

- O teatro negro é diverso, com infinitas possibilidades estéticas, daí a importância da constituição de grupos e coletivos, além das produções individuais, que experimentem, desenvolvam e aprofundem suas próprias investigações de acordo com 
suas poéticas e sua visão político-social;

- No que se refere ao negro como sujeito da sua história, haveria uma mudança de ponto de vista: nos teatros negros, ele poderia atuar buscando outros caminhos, existir distante das concepções de subalternização e desumanização;

- As dramaturgias seriam pautadas no ser e fazer negro e em um olhar negro sobre a realidade; deveriam ser escritas por negros e ser reconhecidas pela sua comunidade; o teatro negro seria arte e não poderia deixar de ser engajado politicamente porque o artista negro teria que estar consciente das consequências históricas e sociais da representação, da presença de um corpo negro em cena, afirmando sua individualidade, subjetividade e potencialidades.

No segundo dia, o grupo decidiu listar os principais tópicos convergentes, ocasião em que fui escolhida como relatora para a plenária final. Essa escolha surgiu a partir do reconhecimento do grupo, pois, desde o início dos trabalhos do GT, tentei encaminhar a discussão, fiz anotações e procurei, de forma didática, organizar os temas discutidos e pontos elencados pelo grupo. Além disso, nos outros fóruns, sempre procurei discutir, propor que a questão estética, assim como a política, também fosse debatida no fórum.

O grupo reconheceu minhas falas durante os outros eventos, conhecia a pesquisa e meu interesse pelo tema. Assim, no primeiro dia, anotei os tópicos principais. O debate começou com a resposta à pergunta: o que é estética negra/teatro negro na concepção do seu grupo ou nas suas produções? Todos os representantes de coletivos, grupos ou artistas independentes apresentaram seu trabalho e falaram sobre a estética produzida. 


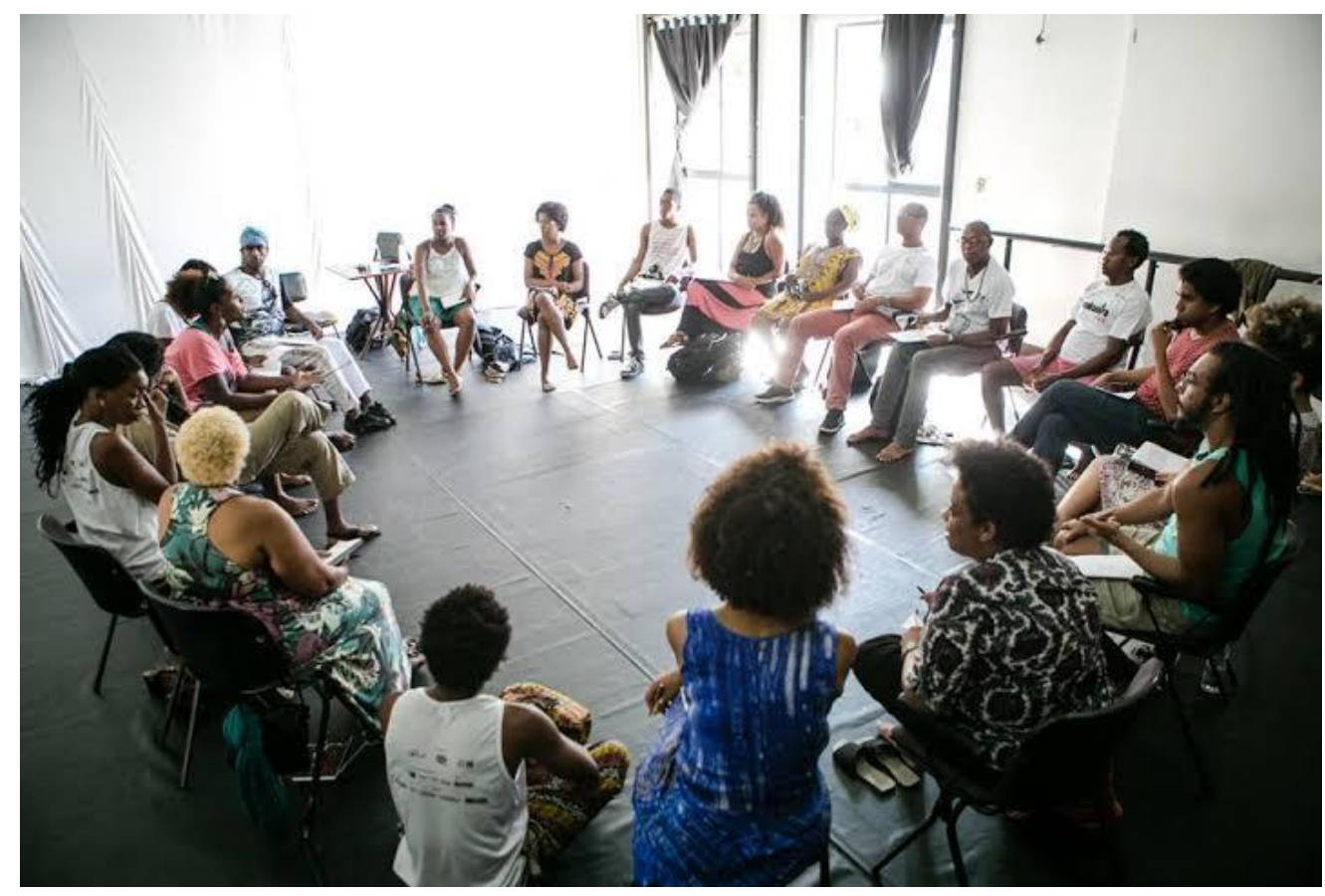

Figura 2 - Artistas reunidos no GT, em dezembro de 2015

Foto: João Meirelles

As falas convergiram no que se refere às temáticas escolhidas pelos grupos, que remetem à ancestralidade negra, às heroínas e aos heróis negros, à subjetividade, à identidade negra, à criação de personagens para além dos maniqueísmos de bem e mal, humanizadas, distantes dos estereótipos criados com ênfase na escravatura, ao enfrentamento do racismo e da opressão, às memórias, às histórias e à religiosidade africana e afro-brasileira. Todos concordaram, afirmando o desejo de criar histórias com outros pontos de vista, outras versões diante das histórias de subalternização predominantes na concepção colonial.

Também foi um ponto importante do debate a percepção da dificuldade de nominação de um teatro negro, de uma forma única para a definição do termo, visto que os grupos consideraram fundamental refletir sobre a pergunta sem o objetivo de encontrar uma resposta que fechasse o debate. Foi posto em pauta o fato de que teatro negro/teatros negros é/são esse (s) que ainda está (ao) se formando, formatando, transformando, em função da própria representação do negro e da negra no espectro social.

Com relação ao teatro engajado que a maioria dos grupos do GT produz, houve concordância no que se refere à estética do discurso. $\mathrm{O}$ discurso político presente nos trabalhos cênicos dos artistas apresenta um arcabouço estético diferenciado que traduz a realidade de um teatro marginalizado pelos meios de produção. $O$ foco não seria a marginalização, e sim as saídas criativas encontradas a partir desse desafio, considerando o 
tipo de teatro que cresce pelas margens, cria seus próprios mecanismos de subsistência e ousa invadir os centros.

O teatro engajado apresenta alguns riscos persistentes, pois o engajamento político não pode suplantar as criações nos campos artístico, é preciso estar atento a todo momento e fortalecer a compreensão do compromisso com a produção de obras de arte acima de tudo.

Os artistas também destacaram o desejo de criar além da realidade que os invisibiliza ou estereotipa. Trata-se, sem dúvida, de uma cena negra que grita como forma de existência e de resistência e de demarcação de território no espaço teatral brasileiro. No segundo dia, então, retomamos os pontos marcantes da véspera e alinhavamos um rol de convergências entre as falas do grupo no sentido dos achados sobre a estética negra, o teatro negro, suas características e seus fundamentos. Na verdade, o grupo conseguiu definir que não seria mesmo fácil responder à pergunta: o que é teatro negro? Entretanto, aceitou o desafio de utilizar a pergunta como um campo aberto para a reflexão em busca não de uma resposta, mas de caminhos para as ações artísticas.

Nesse contexto, ao fim dos trabalhos, o grupo elencou pontos comuns das manifestações cênicas dos artistas independentes e grupos negros engajados presentes no fórum.

Ao fim do encontro, os vinte artistas do GT "Investigações Estéticas da Performance Negra" elaboraram um documento que foi apresentado por mim, enquanto relatora, na plenária de encerramento do evento. O referido documento afirmou que as investigações estéticas dos trabalhos cênicos dos participantes do grupo pautam-se por:

- Consciência das possibilidades enquanto artista negro (individualidade, subjetividade e potencialidades);

- Criação de uma performance negra consciente de sua dimensão política, estética e ideológica;

- Construção de personagens negras com dimensão humana, proporcionando o desenvolvimento de suas afetividades, seus conflitos e outros aspectos de sua subjetividade;

- Dramaturgias pautadas no "ser" e "fazer" negro a partir de um olhar negro sobre a realidade;

- Construções coreográficas que respeitem a corporeidade negra, suas especificidades e seus símbolos; 
- Arte feita por negros e reconhecida por sua comunidade;

- Escrita não contaminada pelo olhar eurocêntrico;

- A arte negra é diversa, com várias possibilidades estéticas, daí a importância da constituição de grupos, coletivos e outros agrupamentos artísticos que desenvolvam e aprofundem suas próprias investigações de acordo com suas escolhas estéticas, políticas e ideológicas;

- O negro enquanto sujeito e protagonista das suas histórias não pode ser representado, ele atua;

- Reconhecimento dos mestres negros como formadores de uma linguagem artística e consciência da importância da salvaguarda e continuidade do legado da ancestralidade africana e afro-brasileira;

- Reconhecimento de que o trabalho artístico desenvolvido na performance negra tem valor enquanto obra de arte, podendo ser referência no universo das artes cênicas;

- Liberdade de criação a partir do universo simbólico negro, com seus costumes, tradições, memória, histórias e religiões;

- Subjetividade histórica, política e geográfica.

\subsection{Reflexão sobre os questionários - IV Fórum, dezembro de 2015}

Ao longo do IV Fórum, entreguei a todos os participantes um questionário (Anexo I). Tal opção metodológica da pesquisa fundamentou-se no desejo de conhecer um pouco mais a realidade dos grupos e artistas independentes, divulgar, dar visibilidade aos seus trabalhos e compreender suas escolhas e seus achados estéticos no que se refere ao teatro negro. Alguns participantes responderam durante o evento, outros enviaram posteriormente por e-mail. 
Foram treze os grupos e artistas que responderam ao questionário:

\begin{tabular}{|c|c|c|}
\hline Região & Grupos/Companhias & Cidade e ano de fundação \\
\hline \multirow{3}{*}{ NORDESTE } & Bando Teatro do Olodum & Salvador -1990 \\
\hline & $\begin{array}{l}\text { NATA - Núcleo Afro Brasileiro de Teatro de } \\
\text { Alagoinhas }\end{array}$ & Alagoinhas - 1998 \\
\hline & Cia de dança e teatro Negô d'Água & Juazeiro - 2001 \\
\hline \multirow{10}{*}{ SUDESTE } & Invasores - Cia experimental de teatro Negro & São Paulo - 1993 \\
\hline & Cia Étnica de dança e teatro & Rio de Janeiro - 1994 \\
\hline & CIA dos Comuns & Rio de Janeiro - 2001 \\
\hline & Cia Corpafro - Arte de dançar afro & Rio de Janeiro - 2005 \\
\hline & Grupo Capulanas - Cia de Arte Negra & São Paulo - 2007 \\
\hline & Coletivo de Artistas Negros de BH - Negraria & Belo Horizonte -2008 \\
\hline & Coletivo Black Horizonte (antigo NEGA) & Belo Horizonte -2010 \\
\hline & TeatrIFdel Rei & São João Del Rei - 2012 \\
\hline & Capulanas Cia de Arte Negra & São Paulo - 2007 \\
\hline & Coletivo Montigente & Porto Alegre - 2011 \\
\hline
\end{tabular}

Quadro 3 - Grupos que responderam ao questionário

Fonte: Autor (2016)

\begin{tabular}{|l|l|}
\hline \multicolumn{1}{|c|}{ Artistas independentes } & \multicolumn{1}{c|}{ Cidade } \\
\hline Daniele Anatólio & Salvador \\
\hline Débora Almeida & Rio de Janeiro \\
\hline
\end{tabular}

Quadro 4 - Artistas independentes que responderam ao questionário

Fonte: Autor (2016)

a)

Sobre o período de fundação dos grupos e companhias

A partir dos anos 1990, deu-se o surgimento dos grupos: cinco foram fundados nos anos 1990 e oito são de 2000 em diante. O Bando de Teatro Olodum é o pioneiro e também o responsável, ao lado da Cia dos Comuns, pela criação do Fórum Nacional de Performance Negra. O evento foi realizado no Teatro Vila Velha, em Salvador, espaço onde o Bando de Teatro Olodum é residente desde 1994. A maior parte da trajetória dessa companhia pode ser encontrada nesse teatro.

Talvez o surgimento desses grupos nos anos 1990 e 2000 tenha como pano de fundo o processo de transição democrática do país iniciado nos anos 1980, movimento que caminhou a passos lentos, considerando o governo neoliberal vigente e os investimentos insuficientes nos setores culturais do país. 
Ainda assim, o período pode ter sido propício para o surgimento de grupos de ideologia contra-hegemônica, com estéticas diferentes das regras e dos modos empresariais de produção, sobrevivendo a partir do engajamento coletivo, da experimentação, da vontade de fazer teatro além das circunstâncias, de explorar outras temáticas na cena. O coletivo seria a riqueza, a força motriz desses processos estéticos e ideológicos.

Autonomia, resistência e identidade parecem ser elementos marcantes nas propostas desses grupos, sem sede própria, ocupando espaços improvisados e produzindo na contramão dos grupos beneficiados pelas poucas leis de incentivo vigentes no país, pois o acesso a essas leis exigiria uma capacitação específica e um entendimento dos mecanismos de produção que, em um primeiro momento, os grupos não tinham.

Outro aspecto a evidenciar refere-se aos nomes dos grupos, todos com referências à cultura negra, como forma de afirmar a identidade estética dos seus participantes e assumir uma posição que também é política, aliás, alguns dos artistas afirmaram que o nome afro dificulta, inclusive, a obtenção de patrocínio, pois os empresários não costumam ser simpáticos à ideia de ver suas marcas associadas a grupos artísticos politicamente engajados. Mesmo assim, os artistas não abrem mão de demarcar sua presença no mercado artístico, não cedem diante de qualquer tentativa de escamotear a especificidade da sua criação.

\section{b) A formação dos artistas}

A maioria dos entrevistados tem formação acadêmica em teatro, espaço onde sua especificidade étnico-cultural foi motivadora de inúmeros enfrentamentos geradores do desejo de formar núcleos negros para a atividade profissional, uma vez que os artistas ressaltam a predominância do modelo hegemônico europeu, que não contempla sua diversidade, a escassez de oportunidades no mercado artístico e ainda a diminuta referência às manifestações teatrais negras na grade curricular dos cursos de graduação. Aqueles que se profissionalizaram partindo de experiências com o teatro amador também destacam a opção pela criação a partir das reflexões sobre a identidade negra no país e o desejo de levar essas experiências para a cena teatral. Alguns ingressaram no ensino superior com o desejo de buscar aprendizado técnico para reforçar suas estéticas e os argumentos para o diálogo com outros núcleos de produção. Independentemente da formação, os artistas destacam os percalços de abordar a questão negra em uma sociedade em que ainda persistem o racismo, o preconceito e a discriminação.

Um realce: Abdias do Nascimento, nos anos 1940, na época da criação do Teatro 
Experimental do Negro, alfabetizou alguns dos seus integrantes, formou atores. Impossível não observar o avanço em nossos dias, quando alunos oriundos do ensino superior ou de formações técnicas se organizam, criam seus núcleos teatrais como resposta à invisibilidade de suas questões no meio universitário. Os artistas que não fizeram sua formação na academia agregam aos seus coletivos outros saberes, oriundos da sua participação na dança afro, na capoeira, nas manifestações populares, nos núcleos de artistas da periferia, nas ruas, nos terreiros de candomblé.

\section{c) A metodologia}

Como os grupos e artistas independentes organizam e sistematizam seus trabalhos, que caminho percorrem para seus resultados cênicos? Essas foram algumas das perguntas do questionário abordado na presente pesquisa. Alguns dos tópicos mais citados no que se refere à metodologia foram:

- Improvisação;

- Construção coletiva da dramaturgia;

- Personagens como seres sociais e não seres psicológicos;

- Abordagem de temáticas sociais e políticas de suas regiões;

- Investigação das possibilidades de investigação de elementos oriundos das religiões de matriz africana, especialmente o candomblé;

- Investigação cênica a partir de gestos do cotidiano, oriundos dos espaços urbanos e populares, sensibilização e construção de um corpo dramático por meio da dança, seus aspectos lúdicos e fisiológicos;

- Perspectiva histórica e conjuntural do corpo negro;

- Protagonismo das mulheres negras;

- Treinamento para desenvolver a autoestima e aperfeiçoar a autodeterminação;

- Poética da fisicalidade;

- Oralidade como elemento centralizador do processo criativo;

- Imagens, objetos e sonoridade conectados com a negritude;

- Estímulos sonoros, olfativos, palatais, visuais e exercícios corporais no contexto da ritualidade do candomblé;

- Pesquisa sobre dramaturgia/poesia, textos de autores negros;

- Reinvenção contextualizada de textos da dramaturgia "universal”. 


\subsection{Discursos e estéticas negras}

A discussão aqui fomentada sobre o teatro negro/os teatros negros da contemporaneidade não pretende encontrar respostas conclusivas. Propõe, acima de tudo, a ampliação do debate a fim de abrir caminhos para futuros estudos e pesquisas.

O teatro negro propriamente - que aqui defino como uma manifestação de criadores negros preocupados em oferecer soluções para a pouca participação dos artistas negros na cena brasileira, de modo a desafiar os modelos eurocêntricos predominantes apresenta outra perspectiva de representação dos estereótipos, algumas vezes investindo na exibição e reelaboração desses estereótipos como forma de discussão, outras vezes apontando outros caminhos de representação da realidade.

O deslocamento dos estereótipos não poderá ser imediato nem irrevogável, uma vez que fomos constituídos a partir dessas referências conscientes ou inconscientes, e, portanto, somente uma investigação profunda e orientada poderá alcançar esse alvo. Mas cabe ressaltar que talvez a negação desses estereótipos contribua para o reforço da sua existência, portanto, como artistas, é preciso ter liberdade de criação, de invenção, passando até mesmo pelos estereótipos, esgotando-os, até o encontro de outros caminhos de construção teatral.

Cabe perguntar: existe uma especificidade na manifestação teatral dos grupos de teatro negro? Qual? Os cânones teatrais das culturas ocidentais serão os mesmos utilizados no teatro negro? O teatro negro, como sistema cultural, produz novos signos e códigos, estabelece outras relações? Produz novos elementos para as teorias da recepção? Para responder a essas questões tão complexas, sugiro um diálogo com Geertz (2000), diante do seu discurso elucidativo e eficaz ao apresentar a arte como um sistema cultural:

O que isso implica, entre outras coisas, é que, em qualquer sociedade, a definição de arte nunca é totalmente intra-estética; na verdade, na maioria das sociedades ela só é marginalmente antiestética. O maior problema que surge com a mera presença do fenômeno do poder estético, que seja qual for a forma em que se apresente ou a habilidade que o produziu, é como anexálo às outras formas de atividade social, como incorporá-lo na textura de um padrão de vida específico. E esta incorporação, este processo de atribuir aos objetos de arte um significado cultural, é sempre um processo local; o que é arte na China ou no Islã em seus períodos clássicos, ou o que é arte no sudeste Pueblo ou nas montanhas da Nova Guiné, não é certamente a mesma coisa, mesmo que as qualidades intrínsecas que transformam a força emocional em coisas concretas (e não tenho a menor intenção de negar essas qualidades) sejam universais. A variedade, que os antropólogos já aprenderam a esperar, de crenças espirituais, de sistemas de classificação, ou 
de estruturas de parentesco que existem entre os vários povos, e não só em suas formas mais imediatas, mas também na maneira de estar no mundo que encorajam e exemplificam também se aplica a suas batidas de tambor, a seus entalhes, a seus cantos e danças (GEERTZ, 2000, p. 146).

Para reconhecer a especificidade das manifestações do teatro negro brasileiro, é preciso entender seus códigos próprios, e esses códigos terão que ser analisados dentro do contexto dessas produções e não poderão ser valorados a partir de critérios construídos e adotados como referenciais para outros sistemas culturais. A especificidade do teatro negro tem um destino intencional, que precisa ser reconhecido como o seu valor, a sua beleza, muito além do sistema universal de beleza, totalmente questionável, variável de acordo com contextos culturais.

Todo teatro tem um destino. O teatro grego teve o seu, o teatro medieval também. O teatro elisabetano, sem dúvida, construiu cenários diante de um mundo com necessidades específicas. Augusto Boal destinou sua obra, isso é fato. Os teatros africanos são calcados nas tradições. Existem inúmeras outras formas de fazer teatro. O teatro, forma de representação estética da realidade, está sempre a questionar seu próprio tempo, a apontar caminhos.

O teatro negro também pode ser considerado como um movimento de resgate dos valores da negritude brasileira, da sua própria cultura, dos meios de criação e reflexão sobre a experiência negra.

Ainda sobre a identidade do teatro negro, cabe a inserção de texto de Leda Maria Martins (1995):

\footnotetext{
Que torna o negro negro, que desejos movem seu olhar em face do olhar desejante do branco, sua máscara/contraponto? Que miragens, afinal, inscrevem e imprimem certos sentidos colados a uma cor, metonimicamente traduzida como uma raça e uma cultura na sintaxe das relações sociais? $\mathrm{Na}$ reelaboração das imagens dramáticas que simulam os indivíduos e suas relações intersubjetivas, na reestruturação dos papeis, no movimento sinuoso das personagens, o Teatro Negro reflete essas indagações, acenando para a complexidade inerente ao sujeito e à sua representação cênica. A criação da persona dramática representa, portanto, um dos elementos mais eficazes para a reflexão sobre esse leque de questões, no projeto de desvelamento sígnico e semântico que esse teatro opera e produz (MARTINS, 1995, p. 188).
}

O negro revelado na cena surge em sua complexidade, sem protocolos únicos, instiga a percepção, confronta preconceitos e fala por si, como sujeito diverso que, por meio de sua poética, gesto e grito, incita a sociedade à reflexão. Sem cair no equívoco de julgar como improcedentes ou inconsistentes todas as manifestações culturais que não atendam aos 
modelos hegemônicos, é possível entender as manifestações teatrais produzidas por artistas negros. Para Geertz (2000):

É a incapacidade de compreender essa variedade que leva muitos estudiosos da arte não ocidental, principalmente daquela a que chamamos de "arteprimitiva", a expressar um tipo de comentário que ouvimos com freqüência: que os povos dessas culturas não falam, ou falam pouco, sobre arte. O que esses comentários querem dizer é que, a não ser de forma lacônica, ou críptica, como se tivessem muito pouca esperança de serem compreendidos, os povos que esses estudiosos observam não falam de arte como eles, estudiosos, falam como gostariam que os objetos de seus estudos falassem: em termos de suas propriedades formais, de seu conteúdo simbólico, de seus valores afetivos, e de seus elementos estilísticos (GEERTZ, 2000, p. 146147).

O teatro negro é afirmativo, está comprometido com a construção de um teatro nacional que incorpore a pluralidade da nossa constituição cultural. Como obra de arte, tem um discurso próprio. Em seu sistema de signos, apresenta símbolos que desafiam e dialogam com a sociedade, provocando discussões, ousando encontrar outros sentidos e caminhos diante e além da realidade. Representa a realidade, mas também expressa a realidade de forma própria, criando outros cenários de representação.

Vale a reflexão sobre as significâncias do signo negro no teatro. Leda Maria Martins (1995) traz importante referência histórica e conceitual:

$\mathrm{Na}$ idealização das imagens do negro, o teatro brasileiro, desde o século XIX, tem se apoiado, portanto, em um argumento de autoridade que estabelece, a priori, um valor de significância negativo para o signo negro. No discurso do poder que se manifesta no discurso do saber teatral, o reconhecimento da alteridade reduz-se à negação e/ou à manipulação grotesca da diferença. Desse modo, a elaboração cênica do imago do negro compactua com os valores e temas de uma realidade racista e discriminatória (MARTINS, 1995, p. 43).

Inúmeros embates são decorrentes de nominar os grupos inserindo a palavra "negro" e adjacentes, como já dizia Abdias do Nascimento, visto que a palavra afronta o sistema dominante, uma vez que nos títulos o "negro" está sendo exaltado pelo seu valor, elevado, destacado. Talvez por isso incomode tanto as pessoas o fato de que as companhias de teatro negro levem consigo essa palavra. Exaltar o negro não combina com a realidade racista e discriminatória que o país ainda enfrenta. Essa questão foi levantada, inclusive, pelos artistas e representantes de grupos presentes no GT "Investigações Estéticas da Performance Negra" reunidos no IV Fórum Nacional de Performance Negra, em dezembro de 2015. 
Os artistas e grupos coincidiram quando disseram que, ao nomear seus grupos, receberam várias críticas segundo as quais um grupo formado por artistas negros seria um grupo racista, mas nenhum desses que criticaram pôde refletir sobre o fato de que a maioria das companhias de teatro brasileiro não conta com atores negros ou conta com pouquíssimos deles nos seus elencos, na maioria das vezes, interpretando personagens negras. Se não existe racismo e somos todos iguais, um ator ou uma atriz negra não poderia interpretar quais papéis? Cabe a pergunta diante de uma cena nacional predominantemente embranquecida, calcada nos cânones europeus ainda predominantes.

Outro importante aspecto a destacar é a questão do direito à voz, reivindicado na maioria das produções que não encontram espaço de fala no teatro brasileiro contemporâneo. Mais uma vez, a fala de Leda Maria Martins (1995) poderá contribuir para o entendimento da questão:

Nesse teatro, a fala do negro nunca é a sua voz, muito menos ainda, o seu discurso. Reforçando o emblema da brancura e veiculando os paradigmas sociais ligados às noções de raça e cor, a construção dos personagens, no teatro brasileiro, ancora-se numa ilusória noção de sujeito: no proscênio, a máscara branca, como espelho do bem e do belo; na periferia da cena, a máscara negra, um avesso da branca, um pastiche em que se desenha o mal, o feio, o ridículo (MARTINS, 1995, p. 43).

O teatro negro reivindica em suas estéticas uma nova concepção do negro em cena. Uma escrita dramatúrgica que se afirme utilizando seus pressupostos como referencial, afirmando sua estética, sua dramaturgia, criando em um universo de histórias construídas a partir da visão, da percepção, da sensibilidade e dos saberes do negro. Um teatro negro que fale por si.

Entretanto, é preciso lembrar que existem técnicas específicas, carpintaria indispensável à composição de um bom texto, já que, em se tratando de linguagem artística, o manifesto e o grito não podem salvar um texto mal escrito.

\subsubsection{O corpo negro}

Uma das questões latentes nas discussões do fórum, do qual participaram representantes da dança e do teatro, foi a abordagem do corpo negro na cena, aspecto que considero essencial. O corpo negro foi construído no contexto da escravidão no Brasil, a partir do olhar do colonizador branco. Foi ele quem deu identidade e valor aos corpos negros. 
Pensando nos caminhos possíveis para uma representação além dessas concepções extemporâneas, rememorando o corpo negro fora do escravismo, no tempo das civilizações africanas, no bojo de sua prosperidade e multiplicidade cultural, foi possível arriscar cenários expressivos para os corpos negros.

A cor branca gera luminosidade no espetáculo. Os corpos negros estariam destinados à sombra? Retomo aqui alguns tópicos levantados pelo GT "Investigações Estéticas da Performance Negra" no IV Fórum:

- O que é o corpo negro?

- O corpo é consciência?

- O corpo em relação a outro corpo;

- O corpo imagina como está sendo visto a partir de outro corpo;

- O corpo branco tenta apagar as dimensões do corpo negro;

- Corpo desumano e inumano;

- Corpo negro - presença - consciência negra do intérprete;

- A ancestralidade em cena - encarnada;

- O corpo enquanto tela - capacidade de ressemantizar as coisas.

Os grupos referenciaram o corpo negro em cena a partir de investigações que levaram ao descolamento dos corpos ridicularizados, criaturas sem humanidade, cômicos no sentido depreciativo. Propuseram uma estética em que os corpos em cena desafiariam a violência simbólica secular, histórica, física, social com uma corporeidade que ama, chora, goza, sorri, recordando sua ancestralidade, soberania, ciência e autonomia do panteão africano. Em alguns dos espetáculos teatrais integrantes da programação cultural das várias edições dos fóruns, é possível encontrar vários referenciais da ancestralidade africana nos corpos em cena, como o caso do espetáculo Siré Obá, ${ }^{40}$ de 2009, criação do Núcleo de Teatro Negro de Alagoinhas (BA) (Grupo NATA), fundado em 1998 e dirigido por Fernanda Júlia, mestre em Artes Cênicas pela UFBA.

A montagem de Siré Obá, dramaturgia e encenação, foi produzida inicialmente como uma homenagem aos orixás ${ }^{41}$ do candomblét ${ }^{42}$ e ao povo de santo, por meio dos Orikis,

\footnotetext{
${ }^{40}$ Informações retiradas do questionário respondido pelo grupo, parte integrante do Anexo 1 da presente pesquisa.

${ }^{41}$ Orixás. Ancestrais, divindades africanas criadas por Olorum, que correspondem a diversos elementos da natureza. Disponível em: 〈http://documents.tips/download/link/mitologia-dos-orixas-reginaldo-prandi〉. Acesso em: 16 jun. 2016.

${ }^{42}$ Candomblé. Religião brasileira dos orixás e outras divindades africanas que se constituiu na Bahia, no século
} 
poesia em exaltação aos orixás. Em Siré Obá, os corpos negros em cena reinam ao interpretar os orixás, sua cosmogonia e mitologia, oferecendo ao público uma experiência litúrgica instigante. As músicas em ioruba, executadas ao vivo ao som dos instrumentos de percussão, oferecem diversa experiência auditiva. Os corpos celebram, festejam, ressignificam o universo de sua própria cultura.

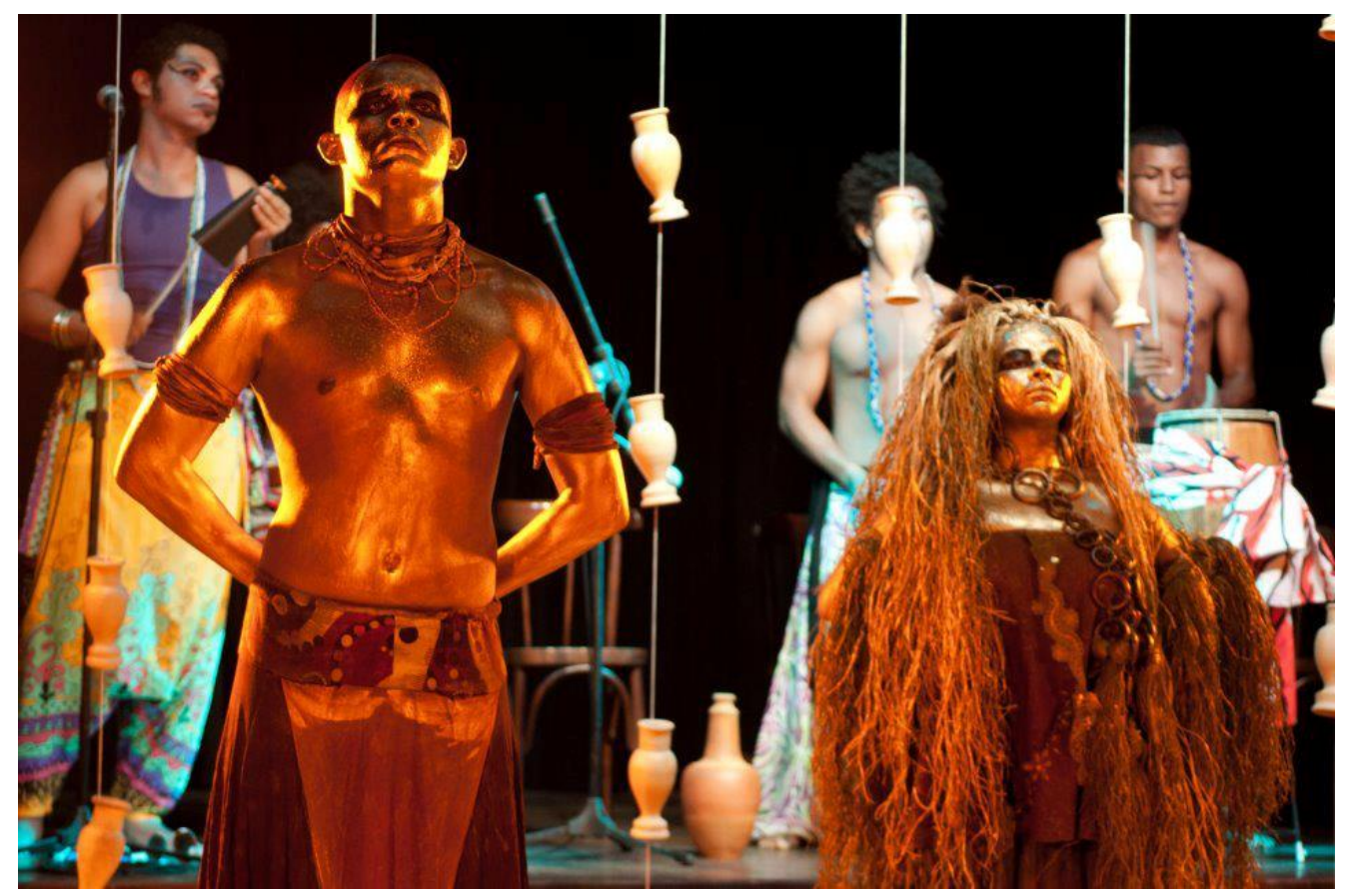

Figura 3 - Siré Obá, a festa do rei. Grupo NATA - atores ao fundo, da esquerda para a direita: Thiago Romero, Deilton José, Cosme Lucian. À frente: Antônio Marcelo e Fabíola Júlia

Foto: Jô Stella, cedida pelo grupo

A imagem reflete o aspecto mítico, ritualizado do espetáculo, uma característica marcante da maioria dos grupos de teatro negro. Leda Maria Martins (1995) também destaca e reflete sobre o papel dos rituais nas religiões africanas:

XIX. Disponível em: <http://www.scielo.br/scielo.php?script=sci_arttext\&pid=S0103-40142004000300015>. Acesso em: 10 jun. 2016. 
Os rituais das religiões africanas e afro-brasileiras exprimem e traduzem, tal qual a tradição africana de que provém, a concepção de que o ser humano é um objeto fenomenal em uma totalidade cósmica, na qual coexistem, sincronicamente, a instância material e a instância divina. No pensamento africano tradicional, de que esses rituais são testemunho, o mundo dos orixás e de Olorum $^{43}$ não está situado em um espaço excludente, em uma esfera inatingível e inacessível, a que o ser humano só pode pretender aproximar-se ou integrar-se através da morte ou da redenção místico espiritual (MARTINS, 1995, p. 126).

Dessa forma, estariam os espetáculos do teatro negro em uma dimensão mítica entre o humano e o sagrado, conectados com a cosmologia africana, com a cultura afrobrasileira, matrizes das quais retirariam suas energias criadoras e motrizes vitais. Os corpos em cena apresentariam a expressão da subjetividade, mas também apontariam para um ser coletivo, que existe e representa.

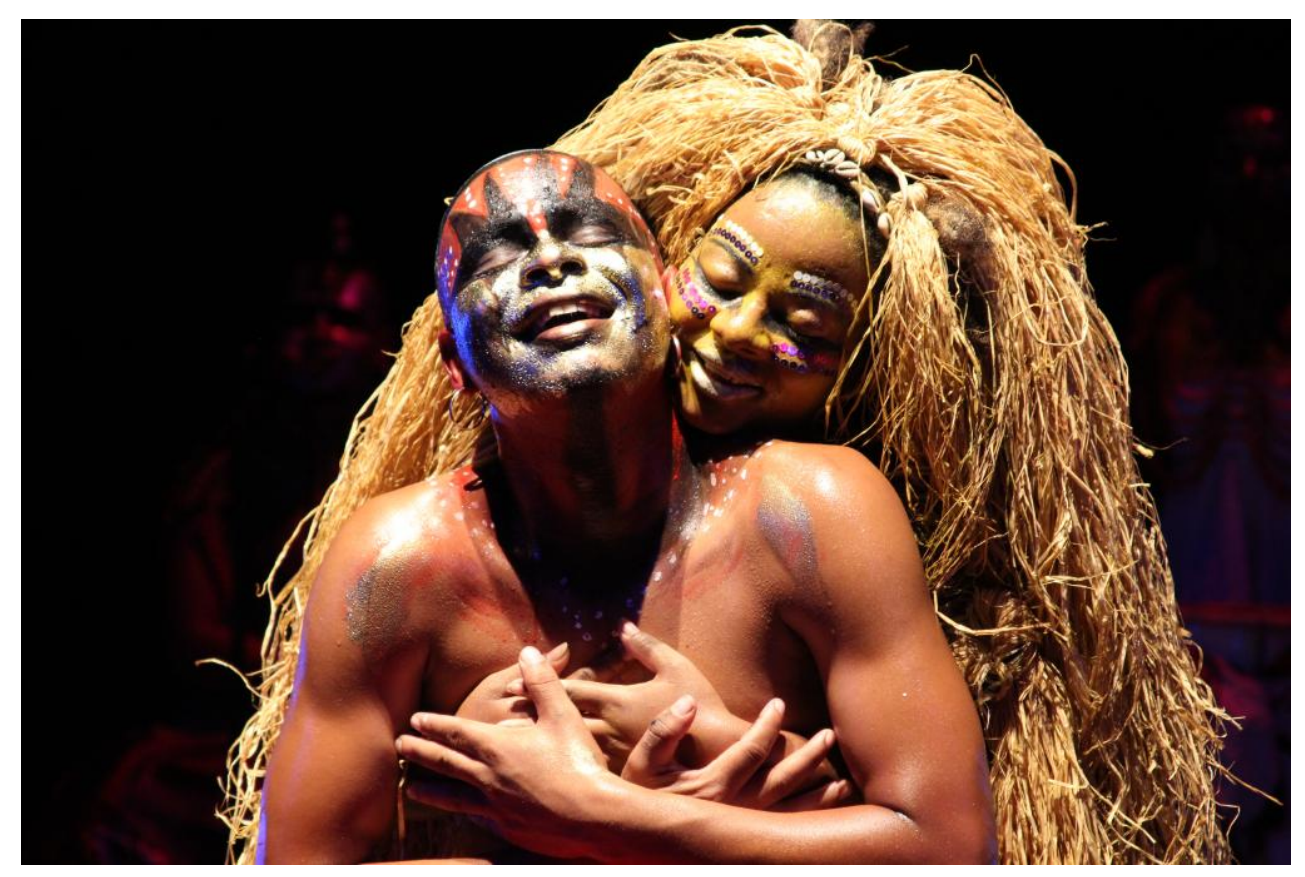

Figura 4 - Cena do espetáculo Siré Obá, a festa do rei. Grupo NATA. Direção: Fernanda Júlia. Em cena, os autores: Nando Zâmbia e Fabíola Júlia

Foto: Andréa Magnoni, cedida pelo grupo

Na Figura 4, um homem e uma mulher negra vivem um momento de afeto, degustando as delícias do amor. A experiência dos povos negros não pode ser limitada aos momentos de dor, o afeto é uma experiência que deve ser aprofundada nas nossas criações, pois é parte da nossa existência em que pesem os estratagemas do racismo e da exclusão

\footnotetext{
${ }^{43}$ Olorum. Termo ioruba para denominar o criador, ser superior acima dos orixás e do homem.
} 
social. Uma foto referência para a questão da humanização, da fuga dos estereótipos, da utilização de outras opções estéticas de figurino, maquiagem e caracterização das personagens do teatro negro.

Merece alusão também o espetáculo Áfricas, do Bando de Teatro Olodum, de 2007, primeiro infantojuvenil do grupo, que aborda o continente africano, sua religiosidade, suas tradições e seus mitos. A peça tem grande contribuição diante da escassez de informações sobre o continente africano, já que várias lendas e contos africanos são encenados, representando aspectos relevantes que se referem ao universo africano, suas experiências cotidianas, o jeito de ser e de viver da gente negra do continente.

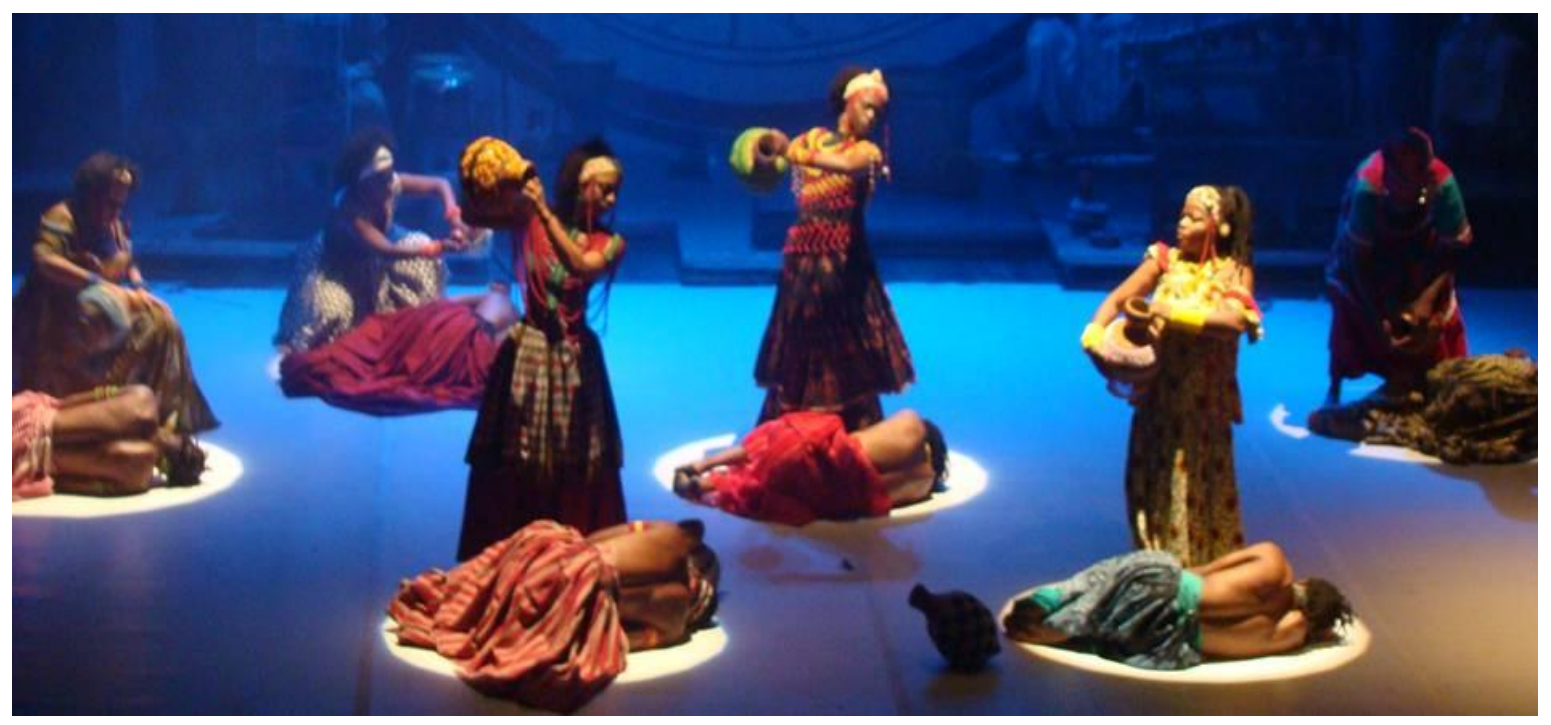

Figura 5 - Bando de Teatro Olodum (BA). Em cena: Valdinéia Soriano, Auristela Sá,

Foto: João Meirelles

O colorido da cultura africana invade a cena nos figurinos, a corporeidade está nas coreografias e na poética corporal dos atores. A dramaturgia coloca em prática a discussão sobre a estética negra em cena; a subjetividade dos personagens, a complexidade das caracterizações além dos maniqueísmos de mal e bem confirmam o processo de humanização das personagens. 


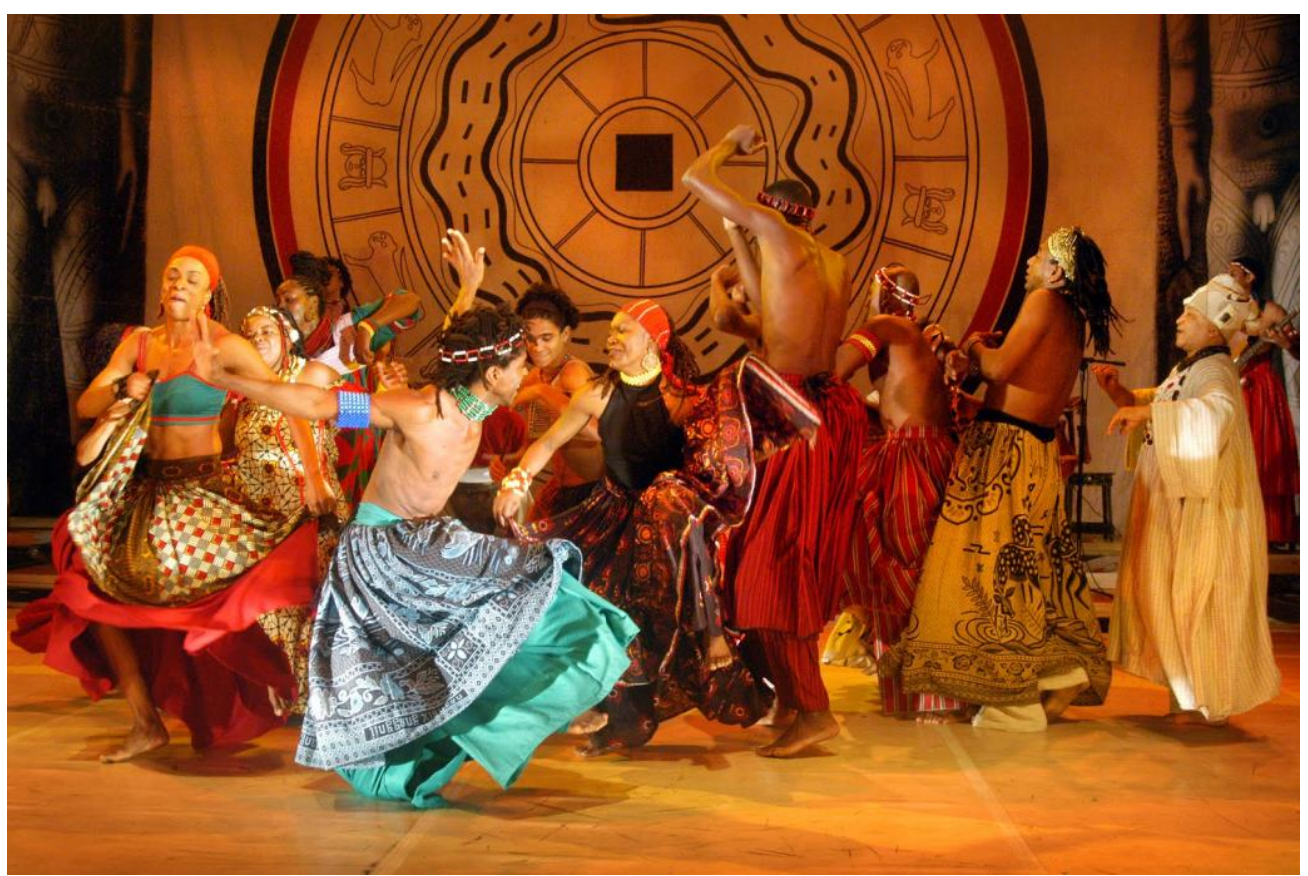

Figura 6 - Atores em cena: Auristela Sá (in memoriam), Ednaldo Sérgio Laurentino, Valdinéia Soriano, Gerimias Mendes, Jorge Washington, Ridson Reis e Telma Sousa

Foto: João Meirelles, disponível em: <http://bandodeteatro.blogspot.com.br/>. Acesso em: 3 jul. 2016.

Esses dois trabalhos que pude assistir apresentam caminhos próprios, especificamente produzidos para a cena teatral negra, utilizam vários dos elementos acima listados na discussão sobre o corpo negro e destinam local de extrema importância às referências da religiosidade e cultura africana, compondo uma cena composta pelo tripé arte, política, religiosidade. Os dois espetáculos dialogam com vários dos tópicos elencados no documento final do GT “Investigações Estéticas da Performance Negra”, como:

- Construções coreográficas que respeitem a corporeidade negra, suas especificidades e símbolos;

- Liberdade de criação a partir do universo simbólico negro, com seus costumes, tradições, memória, histórias e religiões;

- Subjetividade histórica, política e geográfica.

Outro aspecto referencial dos grupos de teatro negro é o uso da música e da dança nos espetáculos. A maioria dos grupos conta com música ao vivo, percussiva, executada pelos atores e, em particular, do Bando de Teatro Olodum (BA) e de alguns espetáculos da Cia dos 
Comuns (RJ), composta especialmente para os espetáculos por Jarbas Bittencourt, ${ }^{44}$ que acompanha o trabalho do grupo, criando desde os primeiros ensaios. A dança também é parte da dramaturgia, contribui para a expressão dos corpos em cena e utiliza referências negras oriundas da capoeira, de danças brasileiras e de códigos gestuais oriundos do candomblé.

Impossível falar da dança no teatro negro e não citar Zebrinha, ${ }^{45}$ bailarino e coreógrafo, um dos nomes mais referenciados na dança no Brasil. Zebrinha tem uma formação de excelência, estudou em vários países, foi bolsista no Alvin Ailey American Dance Theatre (EUA), deu aula na Holanda, na França, na Alemanha e na Bélgica. Após o périplo estrangeiro, voltou a Salvador, assumindo a coordenação do Balé Folclórico da Bahia. Zebrinha tem formado corpos para a cena teatral negra há décadas, sempre priorizando as matrizes africanas e afro-brasileiras como motriz da criação.

A estética negra está presente em cada elemento teatral. Seja nos figurinos, cenário, maquiagem ou iluminação, tudo é criado para favorecer a interpretação dos artistas. A maquiagem ideal para a pele negra, o figurino que destaque as matrizes da criação, a iluminação específica. As cores precisam considerar outras opções de tela, já que não estão em cena os corpos habitualmente integrantes do teatro brasileiro. É na tela negra que será desenhado o panteão de colorações. A pintura cênica precisa considerar esse molde.

No teatro negro, tudo é preparado para destacar, favorecer e privilegiar as especificidades dos corpos negros, pois o discurso precisa ser coerente em cada detalhe, marcando a cena com os traços culturais do povo negro. A forma precisa dialogar com os conteúdos levados a cena.

Os discursos dos artistas independentes aqui citados e a sua estética constituem sua plataforma criativa, sempre em construção. A cena negra contemporânea está conectada com as novas tecnologias, com os recursos sonoros, com as técnicas corporais e vocais que visam à excelência dos corpos em cena.

Os criadores estão em busca de outras opções para a composição teatral. Os discursos estéticos produzidos, no caso das manifestações cênicas desses artistas e grupos,

\footnotetext{
${ }^{44}$ Jarbas Bittencourt. Cantor e compositor, atua como músico profissional há dezoito anos na área da MPB e da Trilha Sonora para Teatro e Dança. Em 1996, iniciou-se no campo da direção musical e criação de trilha sonora para espetáculos de dança e teatro. Trabalha compondo para o Bando de Teatro do Olodum desde a década de 1990. Disponível em: <http://bandodeteatroolodum.com.br/jarbas-bittencourt/>. Acesso em: 15 ago. 2016.

${ }^{45}$ Zebrinha. Desde 1992, é coreógrafo do Bando de Teatro Olodum. Participou da montagem de espetáculos de sucesso como Cabaré da RRRRRaça, Sonho de uma noite de verão, Ó, Pai,Ó e Áfricas, entre outros. Em 2001, iniciou a sua colaboração com a Cia dos Comuns, coreografando A roda do mundo; em 2003, Candaces, da mesma companhia, trabalho pelo qual concorreu ao Prêmio Shell. Em 2005, coreografou o elogiado Bakulo, os bem lembrados, da Cia dos Comuns (RJ). Disponível em: <http://bandodeteatroolodum.com.br/zebrinha>. Acesso em: 15 ago. 2016.
} 
revelam uma cena recheada de especificidades, apresentando uma poética da diferença que almeja trazer aos palcos, ruas e quaisquer espaços reivindicados pela encenação a cultura popular, a oralidade, a religiosidade e as tradições de matriz africana e afro-brasileira, assim como o protagonismo da personagem negra construída além dos maniqueísmos de mal e bem e sua representação como personas críticas diante da realidade. 


\title{
CAPÍTULO III - EU, NEGRA-ATRIZ-DIRETORA-ESCRITORA NO PLANALTO CENTRAL
}

\author{
Não vou mais lavar os pratos \\ Não vou mais lavar os pratos \\ Nem vou limpar a poeira dos móveis \\ Sinto muito \\ Comecei a ler \\ Abri outro dia um livro e uma semana depois decidi \\ Não levo mais o lixo para a lixeira \\ Nem arrumo a bagunça das folhas que caem no quintal \\ Sinto muito \\ Depois de ler percebi a estética dos pratos \\ A estética dos traços, a ética, a estática \\ Olho minhas mãos quando mudam a página dos livros \\ Mãos bem mais macias que antes \\ Sinto que posso começar a ser a todo instante \\ Sinto qualquer coisa
}

SOBRAL, 2011, p. 23.

Eu, negra-atriz-diretora-escritora no Planalto Central. Insisto na constituição da minha referência étnica como parte constituinte da minha identidade cultural. Sinto que estou cada dia mais negra, a partir de dentro, por meio de um processo de autoidentificação. Olhando para trás, percebo que sempre tive um olhar para os paradoxos sociais.

Esse olhar foi motivador de muitos conflitos e de muita solidão. Mas essa percepção me desenha, liberta, revela o que sou. Os paradigmas sempre estiveram presentes. Por exemplo, na medida em que fui crescendo, fui percebendo que a maioria das outras pessoas com as quais eu convivia não tinha consciência da tensão nas relações raciais brasileiras, não acreditava na existência do preconceito racial como algo vigente em suas trajetórias.

O racismo e a discriminação estavam enraizados na nossa experiência, ora no plano inconsciente, ora no consciente. Depois da "libertação" dos negros trazidos ao Brasil em situação de escravidão, não houve uma perspectiva de inclusão ou de cidadania por parte do poder vigente no sentido de convidar esses indivíduos a participar da vida pública do país. Abdias do Nascimento (1978) já disse: 
Atirando os africanos e seus descendentes para fora da sociedade, a abolição exonerou de responsabilidades os senhores, o estado e a igreja. Tudo cessou, extinguiu-se todo o humanismo, qualquer gesto de solidariedade ou de justiça social: o africano e seus descendentes que sobrevivessem como pudessem (NASCIMENTO, 1978. p. 65).

Mesmo diante desse cenário desanimador, que na verdade despertou o desejo de dar visibilidade, de colocar na ordem do dia essa discussão, optei pela investigação sobre a questão racial e suas implicações no meio social e no universo da arte, investindo esforços em estudos e pesquisas, em uma caminhada na qual precisei mergulhar em busca de reflexões e autoconhecimento, além de conhecer algumas pessoas marcantes, viver experiências peculiares e, acima de tudo, aprofundar a leitura e os diálogos com outros autores e pesquisadores. Para o meu alívio, não estive sozinha, conheci mestres incansáveis na busca de sentido e de um horizonte diante dos paradoxos multiculturais de um país onde o mito da democracia racial ainda não foi totalmente desvendado.

Por que boa parte dos brasileiros ainda acredita que vivemos em uma democracia racial? Para começar, porque as elites que nos governaram até hoje precisavam vender essa mentira, aqui e no exterior. a cabeça de uma sociedade é, em geral, feita pela sua classe dominante - com o objetivo duplo de manter seus privilégios e deixá-la dormir em paz (RUFINO, 2005, p. 43).

Alguns dos meus maiores embates raciais foram vividos na infância e na adolescência. Um dos piores lugares para uma criança negra é, sem dúvida, a escola, um dos principais espaços potencializadores do racismo. No ambiente escolar, o debate entre as diferenças e a inclusão ainda não tem sido trabalhado de forma saudável e construtiva. Por isso muitos de nós abandonamos a escola na mais tenra idade. Não estamos representados no espaço escolar. A escola parece querer reforçar a ideia de que há um mundo bom lá fora e que ele não foi feito para nós.

É na escola que são construídos e destruídos os alicerces da identidade negra formada no seio das famílias, com base nos choques e entrechoques culturais. Isso significa que cada identidade seria constituída na hibridização, isto é, no movimento de articulação e síntese dinâmica entre esses determinantes (HALL, 1997).

Na sala de aula, segundo o modelo eurocêntrico de branqueamento, quanto mais avançamos no sentido do conhecimento, mais distantes ficamos da nossa negritude, dos nossos semelhantes, pois, a cada ano, mais negros sucumbem diante do sistema dominante. 
Os modelos apresentados na escola, modelos positivos, são, na sua maioria, modelos não negros. O negro está associado à violência, à ignorância, entre outros estereótipos.

Cursei meus primeiros anos escolares $\left(1^{\mathrm{a}}\right.$ a $4^{\mathrm{a}}$ série) em uma escola particular. Era a escola da Igreja Adventista do Sétimo Dia. Eu era uma das poucas estudantes negras. Era a filha adotiva, rejeitada pelos colegas. Lá conquistei as melhores notas da classe e sofri a solidão, meu cabelo não era bom o suficiente para os padrões do lugar, minha cor de pele, meus traços, as formas do meu corpo, eu não parecia adequada.

Alguns vizinhos diziam que era uma menina de nariz em pé, nem parecia negra, como se estudar em uma escola com mais recursos de aprendizagem fosse uma forma de trair a própria negritude. Tudo isso porque era muito amada por uma mulher branca, no olhar dos outros, enquanto eu enxergava apenas mamãe, que tinha muito zelo por mim. Rígida na disciplina, caprichosa nos vestidos, nos cuidados. Amorosa como as boas mães sabem ser. Eles diziam: "Que absurdo uma mulher branca andando por aí, mimando uma criança negra, como se fosse sua filha!”; "A Marina anda por aí com essa menina, crente que é filha! Quem sabe de onde essa negrinha saiu?".

Fui a menina negra do bairro de subúrbio que estudava na escola particular. As melhores escolas e o saber institucionalizado eram privilégios exclusivos dos brancos, dos que tinham melhores condições financeiras, representavam lugares não conquistados pela maioria das famílias negras. Entretanto, a escola também é um lugar onde podemos aprender coisas para transformar realidades.

Da quinta série em diante, com o falecimento de mamãe, fui para a escola pública, onde passei a estudar daí em diante. Eu gostei tanto da escola! Havia conflitos, mas nós, alunos negros, estávamos lá, em maior número, havia professores negros também, me senti incluída, podia ter voz e lugar.

Assim, fui me adaptando a esse ambiente escolar, sempre perto de toda a literatura disponível. Fazia leitura de tudo, desde bulas de remédios, que podiam me ajudar diante do péssimo atendimento dos hospitais públicos da minha região, aos grandes clássicos da literatura "universal". Segui pelo ensino fundamental até terminar o ensino médio estudando no terceiro ano no turno noturno, em uma escola onde a maioria acreditava que a universidade pública não era pra nós.

Nessa escola, o Centro Educacional 02 de Sobradinho - DF, montei, com meus colegas mais chegados, um grupo de estudos para o vestibular. Estávamos interessados em ir além do conteúdo ensinado nas aulas. Era um grupo de trocas. Cada um ensinava o que sabia 
melhor e, algumas vezes, tirávamos dúvidas com os professores. Ali encontrei motivação para estudar também nas madrugadas, na certeza de que seria possível aprender mais.

No meu percurso educacional, percebi que havia uma forte tendência por parte dos diretores, orientadores e educadores, reprodutores da lógica do sistema vigente no país, com raríssimas exceções, de direcionar tudo o que estava relacionado com a identidade negra para as margens, excluindo nossas manifestações culturais, desvalorizando, mitificando. As experiências negras nunca podiam ser legitimadas no espaço estudantil, nem podiam ser consideradas cientificamente, porque sempre estiveram restritas ao universo mágico, empírico e intuitivo.

Segui estudando até conquistar uma vaga no Departamento de Artes Cênicas como estudante do Bacharelado em Interpretação Teatral, onde ingressei aos dezesseis anos. Sempre sonhei em cursar essa formação. No campus, percebi que o ideário de embranquecimento não era mera impressão: ele estava ali, pude contar nos dedos os estudantes negros com os quais cruzei na minha vida como aluna do ensino superior.

Ainda hoje, na academia, o ideal de "branqueamento" continua a existir de forma sutil e às vezes não tão sutil. Não é possível falar de estética negra sem considerar a normativa da brancura vigente. Dentro da universidade, diante dos paradoxos enfrentados, ainda sinto as garras de um colonizador, mesmo inconsciente, tentando arrancar a minha pele preta e colocar à força uma máscara branca em meu rosto.

Apesar de todas as tentativas de destruição, olho no espelho e me enxergo cada dia mais negra, embora os embates sejam constantes. Frantz Fanon (2008, p. 33) afirma que “o negro tem duas dimensões. Uma com seu semelhante e outra com o branco. Um negro comporta-se diferentemente com o branco e com outro negro. Não há dúvida de que esta cissiparidade é uma consequência direta da aventura colonial”.

Foi na academia, diante de todos os enfrentamentos possíveis e das tentativas de exclusão das diferenças, que me fortaleci e me afirmei para começar o processo de reconstrução da minha identidade negra e impulsionar, com base nos estudos e pesquisas realizadas, as matrizes da minha produção artística. A academia ajudou a encontrar ferramentas para reinterpretar minha realidade, a fazer a leitura e a releitura do mundo à minha volta, a tomar posse de poderosos instrumentos de análise e compreensão.

$\mathrm{Na}$ universidade, forjei meu corpo e gestos, construí um corpo dramático para a interpretação teatral, a escrita para o exercício das dramaturgias, a poética nos caminhos da literatura negra. Na academia, me descobri e amadureci como mulher negra e artista. 
Desde que cheguei ao Planalto Central, na capital do país, em 1991, estive distante dos centros para onde escoa a maior parte dos recursos da cultura, das grandes empresas televisivas, da indústria cinematográfica, mas justamente nesse espaço encontrei liberdade para produzir e experimentar em um contexto distante das grandes produções artísticas comerciais.

Sempre sonhei com os caminhos do teatro e da literatura negra, que foram aos poucos ganhando espaço em minha vida, direcionando meu processo de trabalho, na expectativa de escrever histórias negras e apresentar o universo negro de forma a desvendar os universos de personagens negras tridimensionais com passado, memória e composições não maniqueístas.

O teatro é um espaço privilegiado, onde é possível inventar outras realidades e colocar em cena temas necessários, oferecendo emoção e reflexão ao espectador. Em ação, os conflitos ganham outra dimensão, ainda que efêmera, e esse encontro do texto com o público, por meio do ator, deve ser reinventado, levando em consideração o universo da nossa cultura.

Diante dessa perspectiva, o homem e a mulher negra podem ser representados tanto na literatura quanto no teatro, de forma a reconstruir sua ancestralidade e dialogar com passado, presente e futuro, com total abertura ao conhecimento de experiências de indivíduos negros da diáspora.

No percurso no ensino superior, pude refletir e constituir meu lugar de fala como pesquisadora no campo das artes cênicas diante de um ponto de vista como mulher, negra, brasileira, artista, professora e escritora. Nas peças interpretadas no espaço acadêmico, muitas vezes não pude interpretar os papéis que desejava. Descobri aos poucos que algumas personagens não foram escritas para mulheres como eu. Como primeira atriz negra graduada em Interpretação Teatral pela UnB, em 1998, enfrentei muitas questões referentes à invisibilidade negra na academia.

Nos estudos acadêmicos, o ponto de vista referencial ainda é majoritariamente eurocêntrico, já que não existe, até o momento, um espaço formal constituído para o debate nem um quantitativo significativo de referenciais bibliográficos disponíveis sobre o teatro negro brasileiro, sobre o teatro africano e o teatro sul-americano. Também são poucos os docentes interessados nessas questões. 


\subsection{Cia de Arte Negra Cabeça Feita - Formação}

Após os cinco anos da formação no Bacharelado em Interpretação Teatral, ainda em busca de respostas para a questão da ausência do negro na dramaturgia e nos palcos de um país de maioria negra, criei o grupo teatral Cabeça Feita.

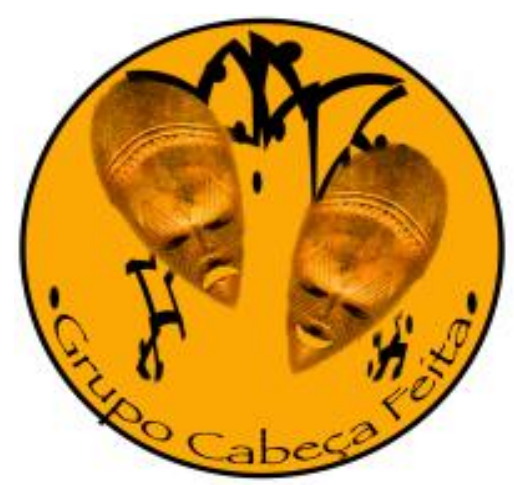

Figura 7 - Logotipo da Cia de Arte Negra Cabeça Feita. Criação: Edson Duavy

O propósito inicial do grupo era discutir e fomentar a estética negra na cena teatral, encontrar alternativas para a pouca participação dos artistas negros na cena local e formar intérpretes negros, combatendo os estereótipos que normalmente norteiam as produções locais e nacionais.

Desde o início, pretendíamos imprimir a estética negra na dramaturgia, nos cenários, nos signos da cena. Também era nosso alvo a perspectiva de inclusão da plateia no encontro do artista com seu público, pois o espírito coletivo é parte da nossa cultura e define quem somos.

A Cia Cabeça Feita foi criada em 1998 e hoje conta com outros atores também formados ou em formação no mesmo departamento, além de artistas da cidade interessados na composição de uma teatralidade e de uma proposta estética alternativa diante da ainda escassa participação e inserção do artista negro no mercado de trabalho.

Com o grupo, formado exclusivamente por atores afro-brasileiros, realizamos vários espetáculos e performances em diversos eventos em Brasília, cidade onde resido desde 1991, e ganhamos alguns prêmios, tendo, inclusive, realizado uma temporada internacional em 2004, na cidade de Luanda, Angola, para onde nos dirigimos a convite da Associação Cultural Chá de Caxinde, para apresentar o espetáculo Petardo, será que você aguenta?, texto de minha autoria em parceria com Dojival Vieira, que reinaugurou o Nacional Cine Teatro, fechado havia vinte e oito anos, com uma temporada de sucesso realizada em um dos espaços 
mais tradicionais da cidade, com oitocentos lugares. Essa experiência foi marcante na história da nossa companhia em função da experiência única de pisar em solo africano e enxergar a nossa identidade negra a partir do contato direto com a nossa ancestralidade.

O grupo insiste na pesquisa e na ousadia do resgate e da produção de uma dramaturgia em que a personagem negra desloque-se da posição de objeto (normalmente propagada em nosso meio) para a posição de sujeito. Um dos alvos da nossa companhia, além de formar atores para o mercado nacional, é formar pensadores críticos sobre a situação do negro no Brasil. O grupo sempre esteve de portas abertas para novos integrantes, com o objetivo de alargar a discussão e dar visibilidade às questões debatidas no interior.

A companhia procura também aumentar a visibilidade da população negra ainda ofuscada por um padrão eurocêntrico que não reflete a realidade multiétnica e fortalecer a identidade e a autoestima dos afro-brasileiros de nosso país, o último a abolir formalmente o trabalho escravo, hoje possuidor do segundo maior contingente de população negra do mundo, ficando atrás apenas da Nigéria. Ao reivindicar um novo lugar para o negro no teatro, procuramos apresentar alternativas para a inclusão afro-brasileira em todas as esferas da sociedade, como produtora de conhecimentos, geradora de riquezas e formadora de opiniões.

As montagens são constituídas com base em dramaturgia própria, assim como em peças de outros autores negros, de textos da literatura negra e da dramaturgia "universal". A metodologia de trabalho do grupo consiste em leitura e estudo de textos teóricos, discussões sobre material bibliográfico e audiovisual, ensaios, preparação corporal e vocal, exercícios de sensibilização e improvisação e intercâmbios com outros grupos de teatro negro.

Dentre as ações do grupo, destaca-se a criação de espetáculos cênicos, de esquetes teatrais e de performances para eventos, palestras, composição de textos teatrais sob demanda, espetáculos poéticos, recitais e abertura de eventos culturais.

A Cia de Arte Negra Cabeça Feita é formada por artistas com formação ou em formação acadêmica em teatro, dança ou música. Também já teve estudantes de Letras e Comunicação, atores amadores, cantores, atores e atrizes, na maioria professores de teatro, músicos, produtores e outros técnicos teatrais.

Fundação: 1998 - Fundada e dirigida por Cristiane Sobral, atriz e diretora

\section{6 - Integrantes da companhia:}

Cristiane Sobral, Diogo Hamlet, Jurandir Luiz e Ricardo Costa. 


\section{Compuseram o elenco da Cia de Arte Negra Cabeça Feita:}

Edson Duavy, Silvia Paes, Nei Cirqueira, Bárbara Tavares (1998-2006)

Luciana Oliveira, Ana Luiz Bellacosta (1998-2001)

Bárbara Tavares (2002-2004) - Direção do espetáculo Petardo, será que você aguenta?

Dojival Vieira (2004) - Dramaturgia do mesmo espetáculo

Pâmela Alves, Zizi Antunes, Thiago Jorge (2003-2005)

Christiane Castro, Peri P. Silva (2002-2008)

Andreila Gomes (2006-2008)

Giovanni Sacramento, Jorge Santoz, Paulo Campelo, Jean Villanova, Késia Glória, Simone

Ramos (2006-2008)

Magno Garrido, Deise Barros, Daniel A. Costa (2006-2010)

Jair Augusto, Wilson Aleixo, Glednna Fernanda (2011)

Hugo Souza e Cleber Alves (2011-2013)

Diogo Hamlet (2008-2016)

Ricardo Costa (2015-2016)

\subsection{Cia de Arte Negra Cabeça Feita - Trajetória}

\section{Espetáculos:}

Flores (2016)

Esperando Zumbi (2015)

Recordar é preciso (2013)

Alisantes anônimos (2013)

Não vou mais lavar os pratos (2012)

Espetáculo de Abertura do Prêmio Expressões Afro-Brasileiras (2010)

Estátuas de sal (2006)

Comédia do absurdo (2005)

Petardo, será que você aguenta? (2004)

Ciclo de Leituras Dramáticas - Textos do PAS (2002)

Dra. Sida - Essa mulher vai fazer a sua cabeça (2002)

I Ciclo de Leituras Dramáticas - Autores Negros (2001)

II Ciclo de Leituras Dramáticas Dramaturgia Negra (2001)

Uma boneca no lixo (1998) 
Concebi a dramaturgia dos espetáculos Uma boneca no lixo, Dra. Sida - Essa mulher vai fazer a sua cabeça, Petardo, será que você aguenta? Em parceria com Dojival Vieira: Não vou mais lavar os pratos e Flores.

\section{Descrição dos espetáculos}

Uma boneca no lixo - monólogo cênico-musical que discute o mito da democracia racial brasileira. Peça em 1 ato e 10 cenas com a participação do grupo afro cultural Asé-Dudú. Foi selecionado pelo Projeto Arte Por Toda Parte para realizar várias apresentações a convite da Secretaria de Cultura do Distrito Federal em 1999. Além disso, foi apresentado em Brasília, Porto Alegre, Rio de Janeiro e Salvador. Esse espetáculo comemorou dez anos da sua estreia em 2008.

Dra. Sida - comédia musical que discute a sexualidade em tempos de Aids e demais doenças sexualmente transmissíveis. Espetáculo patrocinado pelo Ministério da Saúde do Brasil já assistido por mais de sete mil pessoas.

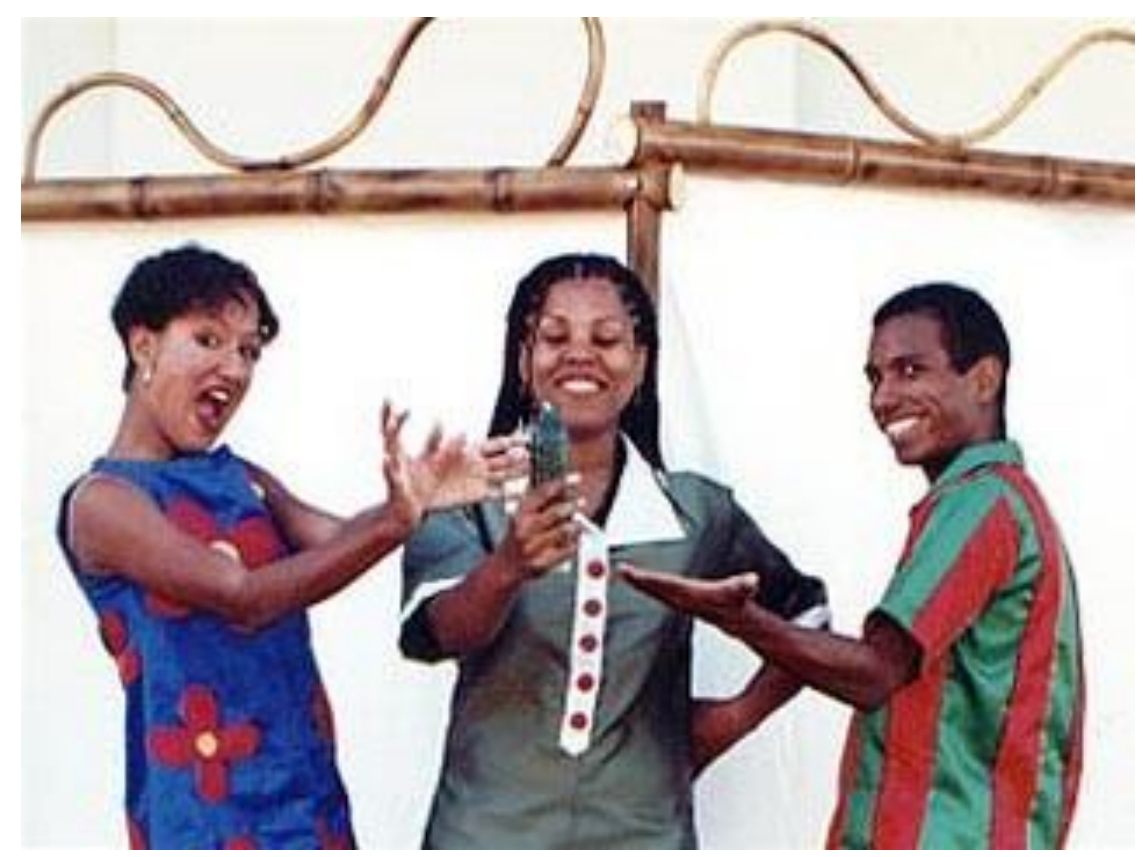

Figura 8 - Dra. Sida - essa mulher vai fazer a sua cabeça

Foto: Dalton Camargos 
Petardo, será que você aguenta? - história de amor com protagonistas negros. Composta por uma série de poemas e diálogos, tem três personagens: Atenusa, Perseu e Aeroermex, o mediador, observador ativo e participante da relação amorosa entre as duas personagens. Atenusa, "Mulher negra de 25 anos, militante do movimento negro, escritora, solteira, em busca de um grande amor, romântica, instável e extremamente sensual" e "Perseu, homem negro de trinta anos, em um processo de autoafirmação da sua identidade negra. Sensível e sonhador. É jornalista e advogado. Procura fugir dos estereótipos normalmente atribuídos aos negros. Espetáculo apresentado em maio de 2004, na cidade de Luanda/Angola, patrocinado pela Petrobras e pela Odebrecht S.A, reinaugurou o Nacional Cine Teatro de Luanda. Fez temporada em Brasília, na sala Cássia Eller do Teatro Plínio Marcos, no mesmo ano.

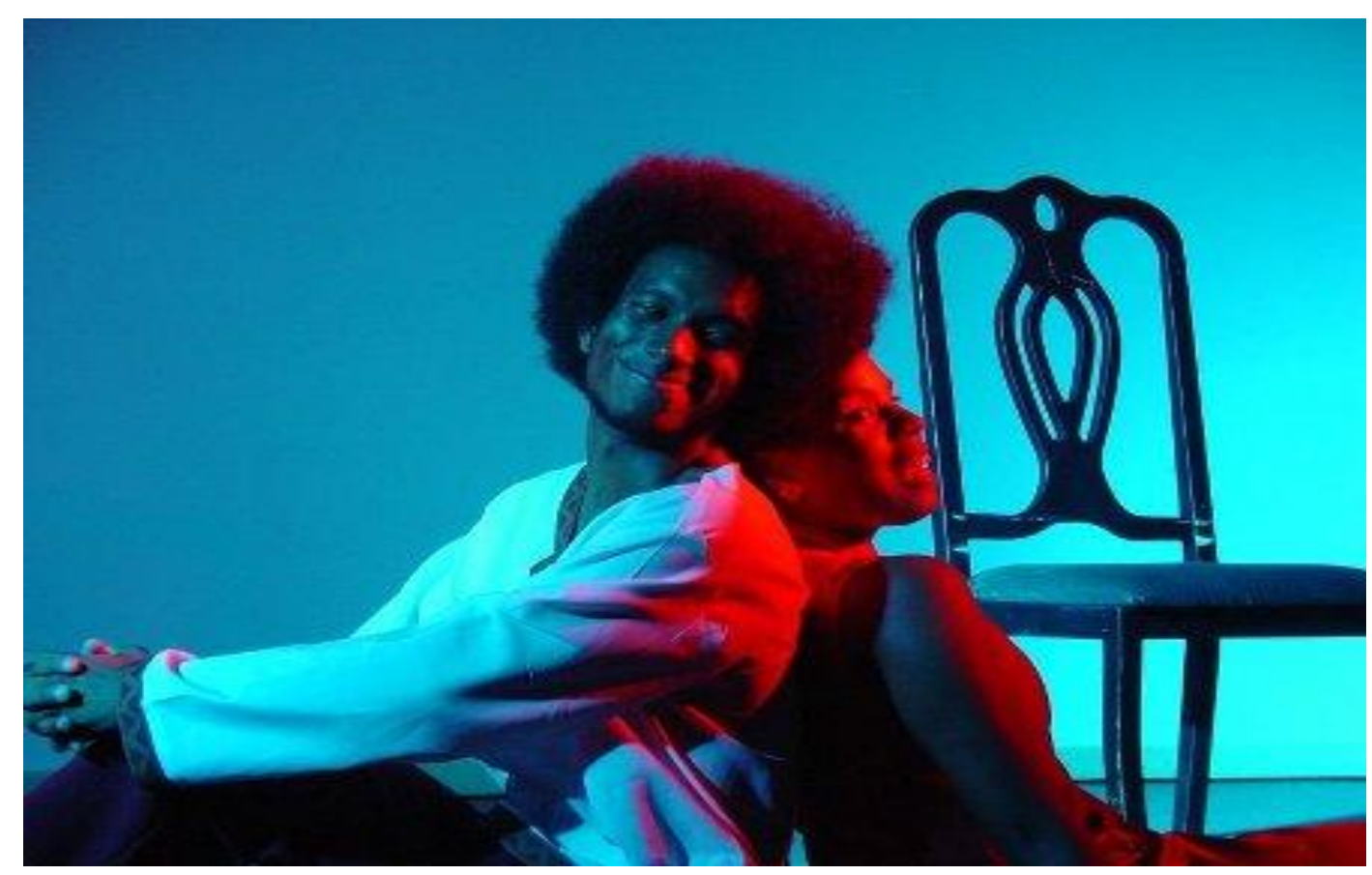

Figura 9 - Petardo, será que você aguenta?

Foto: Jurandir Luiz

Comédia do absurdo - o espetáculo apresenta uma reflexão atual sobre as relações raciais no Brasil. De forma sensível, lúdica e direta, sugere alguns dos possíveis caminhos para a inclusão da negritude brasileira na vida pública do país, o resgate de sua autoestima e o exercício pleno da cidadania.

Estátuas de sal - espetáculo visualmente contundente e de conteúdo forte. Uma família dilacerada pela violência é construída passo a passo, em diálogos minimalistas e silêncios 
prolongados, em uma performance que prima pelo cuidado gestual minimalista e tem como foco a criação de imagens e sensações de maneira simples, concreta e intensa. Foi construído durante a Oficina do Projeto 3 X 4, ministrada pelo Grupo Galpão (MG), que contou com a participação de três grupos teatrais da cidade, entre eles a Cia de Arte Negra Cabeça Feita e quatro profissionais do Grupo Galpão. O grupo foi selecionado e convidado pelo Grupo Galpão para participar do projeto.

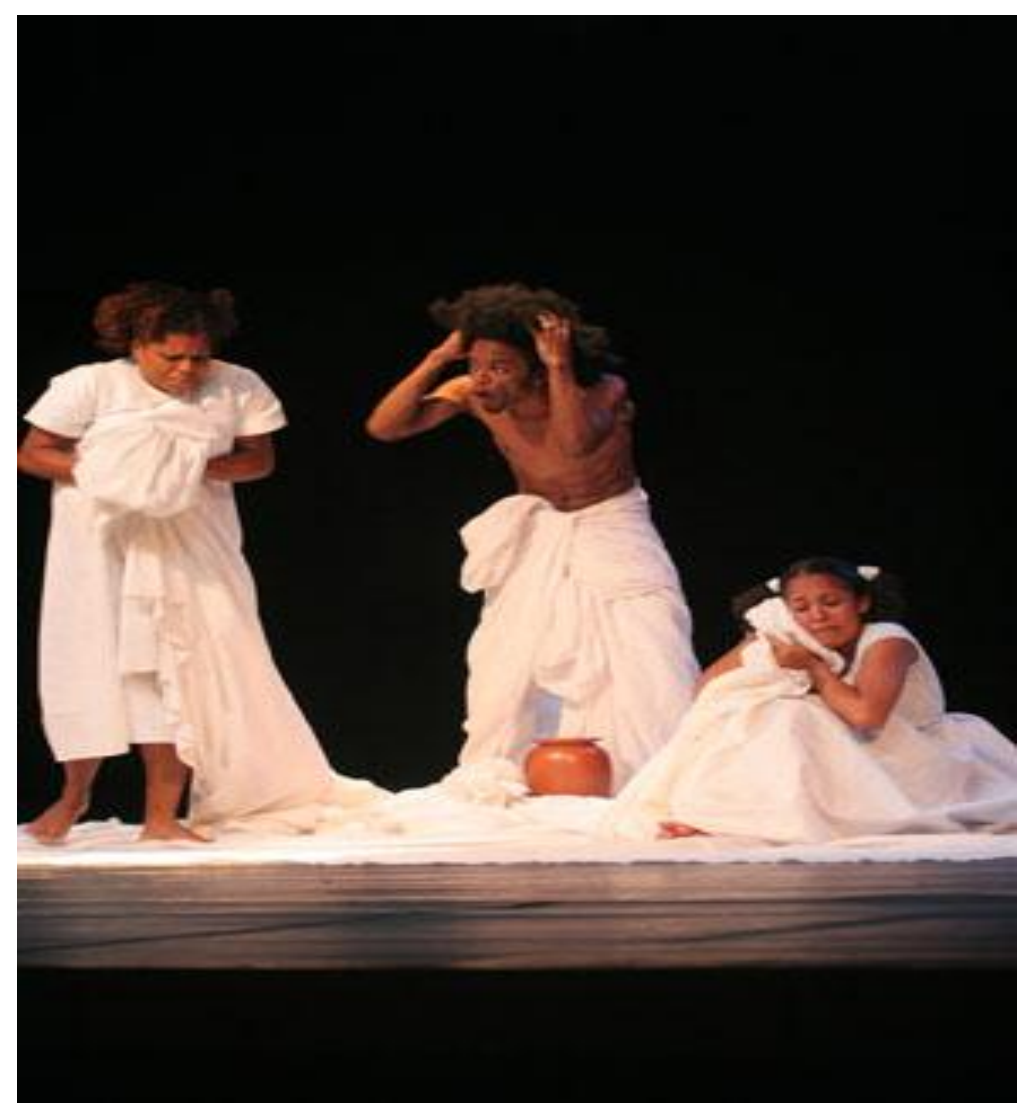

Figura 10 - Estátuas de sal. Em cena: Cristiane Sobral, Thiago Jorge e Zizi Antunes Foto: Vitor Souza

Não vou mais lavar os pratos - espetáculo cênico musical com textos poéticos de Cristiane Sobral, publicados no livro homônimo. A dramaturgia foi construída a partir das histórias contadas no livro em que a autora compartilha experiências vividas, expressas por um grito de liberdade envolvente que leva o leitor a reflexões sobre questões cotidianas tais como: o que é ser negro no Brasil? Quais são os caminhos de afirmação da identidade negra? Como reagir diante das estratégias de embranquecimento impostas pela sociedade? Como afirmar a identidade negra? Com humor e contundência, esses são alguns dos temas abordados pelo espetáculo. 
Espetáculo de abertura do Prêmio Expressões Afro-Brasileiras - esquete teatral produzida a partir de adaptação de texto teatral de Elísio Lopes Jr.

Alisantes Anônimos - $A A$ - peça que aborda, por meio do humor e da música, alguns dos desafios da construção da identidade negra no Brasil. São quadros curtos, durante os quais personagens, alinhavados pela história de Nina, a protagonista, vão revelando seus paradoxos. O AA é um grupo de apoio para pessoas com dependência química de produtos para o alisamento capilar. Essas pessoas reúnem-se no grupo em busca de estratégias para lidar com os conflitos de identidade diante do racismo brasileiro. Nina é a coordenadora do grupo de apoio. O espetáculo é a encenação de uma das sessões de trabalho do AA.

Recordar é preciso - performance constituída com textos de Cristiane Sobral e Conceição Evaristo, poesia, teatro, música. Os textos foram alinhavados de forma a exaltar a força e o protagonismo das mulheres negras, suas batalhas e vitórias. A estética realça a beleza da mulher negra empoderada, confiante, resiliente. O passado, a tradição, a subjetividade feminina são alicerces dessa criação.

Esperando Zumbi - monólogo em construção. Uma mulher em conflitos de identidade e subjetividade espera Zumbi dos Palmares, o Zumbi de ontem, o de hoje, ela Zumbi.

Flores - performance poética de Cristiane Sobral e Ricardo Costa.

Projeto Ciclos de Leituras Dramáticas - eventos gratuitos com leitura de peças do teatro negro nos principais teatros da cidade, seguidos de debates com o público em geral. O projeto foi criado com o objetivo de preparar os atores que chegavam ao grupo com técnicas de dicção, projeção, expressão verbal e interpretação, potencializadas no exercício público da leitura dramatizada. As leituras sempre tiveram acompanhamento musical, ao vivo, e contaram com uma encenação mínima a destacar os elementos essenciais para a montagem, tais como acessórios, peças de figurino e objetos de cena. Peças apresentadas:

- Ciclo de Leituras Dramáticas Autores Negros - Objetivo: discutir os rumos do teatro negro brasileiro, a dramaturgia negra e a relação do teatro com os paradigmas da negritude no Brasil.

- Peças: Sortilégio - Mistério negro, de Abdias do Nascimento; Madrugada me proteja 
e Nódoas, texto de Cuti; Disfarça e chora, texto de Robson Graia.

- Ciclo de Leituras Dramáticas Dramaturgia Negra - Anjo negro, de Nelson Rodrigues.

- Ciclo de Leituras Dramáticas Autores Brasileiros - O juiz de paz na roça, de Martins Penna.

- Oficinas - Oficinas de teatro negro em escolas, empresas, grupos teatrais.

- Palestras - Sobre teatro negro em escolas, empresas, embaixadas, centros culturais etc.

O espetáculo Uma boneca no lixo, primeiro trabalho da Cia de Arte Negra Cabeça Feita, foi marcante em minha trajetória. Ficou mais de dez anos em cartaz, realizando apresentações no DF e em outros estados brasileiros. Nesse monólogo, eu atuo, danço e canto, interpretando um total de doze personagens.

A criação do espetáculo ocorreu no último semestre do curso na UnB. Eu cursava o período letivo com mais uma estudante, que trancou a matrícula. Passei, então, a ser a única aluna regular justamente no momento em que seria avaliada pelo projeto de diplomação, que normalmente envolvia a direção de um professor do departamento, concepção coletiva dos estudantes formandos e a atuação em um espetáculo teatral, além da produção de um trabalho monográfico.

Eu havia escrito o texto teatral Uma boneca no lixo já fazia um tempo e guardara em alguma gaveta. Pensei que aquela seria a oportunidade ideal para montar o texto. Para isso, precisava convencer o professor da disciplina - o multiartista Hugo Rodas, ${ }^{46}$ um dos mais celebrados diretores teatrais do país, seria responsável pela direção do espetáculo de fim de curso naquele segundo semestre de 1998 - de que aquele texto seria a melhor opção para o projeto. O professor Hugo já tinha, naquele momento, vários textos na cabeça.

Um pouco temerosa, mas desejando aproveitar a oportunidade única, fiz a seguinte proposta: montaria uma cena do espetáculo, convidaria o Hugo para assistir o trecho encenado e, se ele gostasse da proposta, toparia a direção do texto.

$\mathrm{Na}$ data marcada, preparei o que seria meu figurino, alguns objetos de cena e convidei o professor para entrar na sala de aula. Hugo assistiu à cena atentamente e, ao final, deu algumas orientações e pediu que eu refizesse a apresentação. Naquele momento, entendi que ele já estava envolvido com o projeto. Selamos, então, uma parceria para a concepção do espetáculo. Ele me confessou, tempos depois, que nunca tinha refletido sobre a participação

\footnotetext{
${ }^{46}$ Hugo Rodas. Doutor Notório Saber em Artes Cênicas pela Universidade de Brasília. Professor Titular da UnB durante mais de 20 anos. Nascido no Uruguai e radicado há mais de 30 anos no Brasil, o diretor, coreógrafo, ator, bailarino e professor Hugo Rodas é um dos mais talentosos e importantes diretores de seu tempo. Disponível em: <http://objetosim.com.br/7-x-rodas/>. Acesso em: 28 jun. 2016.
} 
dos artistas negros no teatro, que o projeto oportunizou a constatação do racismo no Brasil, realidade que nunca havia confrontado antes.

Com muitos desafios, ensaios, estudos e preparação corporal, chegamos à estreia do espetáculo, que foi, sem dúvida, marcante. Estavam comigo em cena os percussionistas do grupo afrocultural Asé Dudú e juntos ocupávamos o palco nos sessenta minutos do espetáculo, cuja ideia central era: como é difícil ser diferente!

Essa afirmação estava presente na trajetória dos doze personagens negros apresentados na peça. Uma boneca no lixo ficou em cartaz por mais de dez anos e foi apresentado em várias cidades brasileiras, sempre com sucesso de público e de crítica. Saí da universidade com um texto que eu escrevi, debaixo do braço, e com uma peça montada, elementos que foram fundamentais para minha profissionalização e ingresso no mercado teatral. A presença do diretor Hugo Rodas também foi fundamental na minha caminhada. Ele sempre foi muito rigoroso e foi com ele que aprendi algumas regras do fazer teatral que trago comigo até hoje e levei para o grupo. A título de exemplo, durante a primeira montagem do espetáculo, além da preparação física nos ensaios, tive que correr todos os dias, desde o início dos ensaios, durante uma hora no mínimo, para melhorar o condicionamento físico. Desde então, a corrida virou parte do meu processo de treinamento e preparação de atores. 


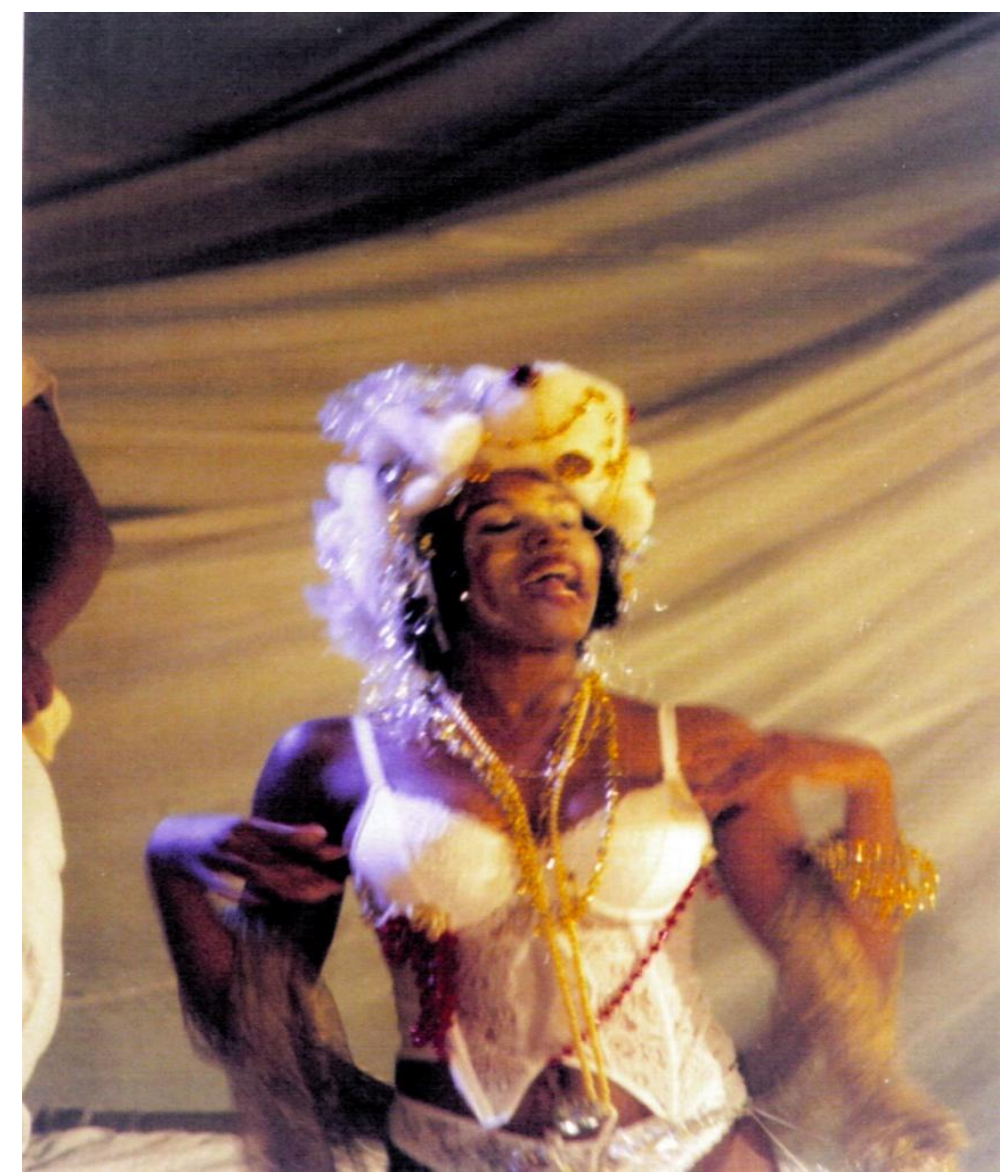

Figura 11 - Uma boneca no lixo. Em cena: Cristiane Sobral, 1998. Sala Saltimbancos do Instituto de Artes da UnB

Foto: Luiz Alves

Hugo Rodas sempre acreditou no meu talento como atriz, até mesmo quando eu não acreditava. Depois da formatura, ele me convidou para participar de várias montagens profissionais que dirigiu fora da universidade, ocasião em que fui aprendendo as regras do jogo teatral, a contracenar com os mais diferentes intérpretes e a conviver em ambientes bem diferentes do espaço acadêmico. Trabalhar com profissionais exigiu muito de mim, tive que aprender na marra, aprender rápido para aproveitar a oportunidade recebida.

Eu estava formada, com o meu registro profissional em mãos e já começando minha trajetória artística nos palcos brasilienses. Finda a universidade, coloquei o espetáculo no circuito comercial da cidade e começamos a ganhar algum dinheiro e a receber um público significativo em nossas apresentações.

Com esse espetáculo, pude aprender não só os meandros da interpretação, como também os manejos da produção, elaboração de projetos, estratégias de divulgação, elementos fundamentais para a sobrevivência de qualquer artista no mercado. 


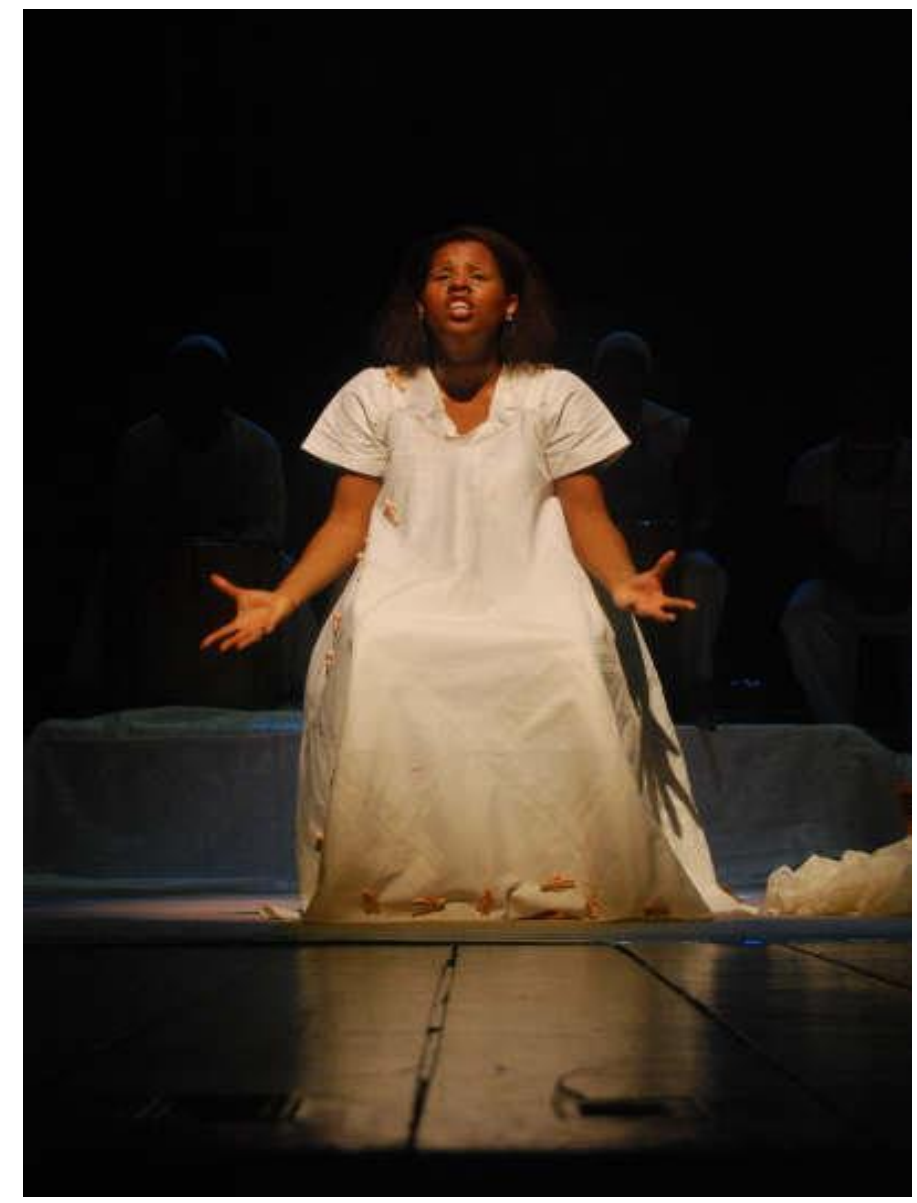

Figura 12 - Dez anos depois (2008). Mostra Dulcina. Teatro Dulcina. Brasília

Foto: Vinícius Guarilha

A seguir, apresento um trecho do texto do espetáculo, dito pela personagem da Figura 12, Ióli:

\section{Cena 5}

\section{Personagem: Ióli}

De dentro de um cesto de palha, com um único movimento, pontuado pelo toque percussivo dos músicos, surge o rosto da menina Ióli, que sorri muito para a plateia, fazendo várias poses fotográficas, ao mesmo tempo em que deixa o cesto no chão e coloca no pescoço uma placa de madeira pintada de vermelho com letras pretas, com um cordão prateado onde se lê "adota-se". Ióli senta no banco de madeira no centro do palco.

Ióli - Ah... Tem umas coisas que eu não consigo entender. As minhas mãozinhas... por que que as mãozinhas são brancas por dentro? Não consigo entender! Os meus pezinhos. Por que os meus pezinhos são brancos por dentro? Não consigo entender. Por que que a vaca pretinha dá leite branco? Não consigo entender. (Ao falar não consigo entender, Ióli cruza os braços estendidos acima da cabeça. Ao falar das mãos, aponta para elas, da mesma 
forma que os pés, e permanece sentada durante todo este trecho). Outro dia no parque, as crianças falaram para mim: (imita as crianças) - A gente não vai brincar com você porque você é preta e suja. Ióli responde: - Eu não sou suja, tá, minha mãe me dá banho, minha mãe penteia o meu cabelinho, eu sou a única criança da minha escolinha que não pegou piolho (congela na foto "criança feliz"). Ah, tem umas coisas que eu não consigo entender! Também lá na minha escola ia ter o desfile do sete de setembro, e eu me preparei toda para ser a primeira da fila, só que, quando eu cheguei lá, a professora me disse que eu não podia ser a primeira da fila, disse que eu seria a última da fila, e eu falei: - Professora, por quê? Eu sou uma ótima aluna, eu tenho ótimas notas, por quê, professora, por quê? (chora desesperada como um bebê recém-nascido encontrado na lata de lixo). Ah... Tem umas coisas que eu não consigo entender... (reflexiva) Outro dia lá na minha escola ia ter uma peça de teatro, e a professora me disse (suspense), ela me disse que tinha um papel muito especial pra mim! Cheguei à minha casa, contei para a minha mãe, ela fez um vestido bem bonito, todo azul, com babadinhos e fitinhas de renda... Só que, quando eu cheguei à escola, a professora me disse que eu ia fazer papel de bruxa, que eu podia até pegar na vassoura, mas pra sair voando (chora como o bebê no lixo). São essas coisas que eu não consigo entender. (expressa raiva crescente e vai acenando com a cabeça, inconformada).

Outro momento de destaque na trajetória do espetáculo foi a apresentação no Teatro da UERJ, treze anos após a estreia da peça, na programação cultural da PréConferência Nacional contra o Racismo e a Intolerância, realizada nos dias 6, 7 e 8 de julho de 2001, na UERJ. Havia mais de 2.000 espectadores no teatro. Militantes negros de várias cidades brasileiras.

O público assistiu em silêncio, aplaudiu de pé. Na plateia estava o meu pai, Jacy Neves Nascimento Jesus, que pela primeira vez assistiu a um trabalho teatral apresentado pela filha. Meu pai sempre expressava certa desconfiança em relação às oportunidades de êxito para uma artista negra. Um dia confessou que não era contra a minha profissão, mas que temia o fato de que talvez ficasse relegada a papéis sem expressão e personagens que não existiam além do contexto da escravidão. Meu pai ficou extasiado com a apresentação. Foi a primeira e última vez que me viu em cena.

Quando escrevi a peça, queria fazer um texto protagonizado por uma mulher, que contemplasse as especificidades de uma atriz, considerando sua subjetividade, a experiência negra, suas tradições e o enfrentamento do racismo. Após o espetáculo na UERJ, recebi com emoção o reconhecimento dos espectadores. Foi indescritível a sensação de apresentar para tanta gente e receber um retorno tão positivo da plateia, contemplada com as discussões abordadas cenicamente. Esses foram os primeiros passos da minha trajetória profissional como atriz e dramaturga. A partir daí, comecei a pensar em montar um grupo, em encontrar parceiros, em fundar um coletivo de teatro negro. Estava aí o embrião da Cia de Arte Negra 


\section{Cabeça Feita.}

O que me levou a criar um grupo de teatro formado por artistas negros? Várias questões, como o desejo de discutir aspectos que dificilmente poderíamos abordar em outros grupos; de criar outras oportunidades profissionais, porque não recebia muitos convites para trabalhar a não ser que os papéis remetessem ao contexto do escravismo; por incrível que pareça, criar um coletivo negro fazia parte do nosso desejo como atores, de interpretar quaisquer papéis, o que muitas vezes parecia impossível de ser aceito por muitos diretores, dramaturgos, que diziam que não tínhamos o físico adequado para fazer personagens clássicas, só para citar um exemplo. Fui motivada ainda pelo desejo de aperfeiçoar o ofício porque, se o ator negro trabalha pouco e interpreta sempre os mesmos papéis, não se torna um ator versátil, nem aprimora suas qualidades técnicas, não amadurece no ofício.

A primeira dificuldade que enfrentei na fundação do grupo Cabeça Feita foi conceitual. Que tipo de trabalho pretendia fazer? O que seria pertinente discutir no âmbito da cena? Muitos questionaram a necessidade, a pertinência e a relevância de um teatro negro. Seria um manifesto racista? Seria uma tentativa de criar um gueto? Um manifesto político?

Estávamos totalmente comprometidos com a discussão sobre a estética negra em cena, ou a raríssima participação dos atores e atrizes negros nas produções teatrais nacionais, assim como a existência de estereótipos cristalizados nas poucas personagens encontradas na dramaturgia, fato que afirmava, sem dúvida, a existência de um teatro reprodutor da hegemonia dos modelos europeus.

Constituído o coletivo, investimos na nossa formação intelectual e no apetrechamento do corpo cênico.

Diante da escassez de artistas negros nas montagens da cidade, muitos criadores cênicos diziam que até gostariam de ter um ator ou atriz negra no seu elenco, mas destacavam a dificuldade de encontrar um bom profissional. Mas como melhorar na profissão sem oportunidades de trabalho? Como poderíamos melhorar como intérpretes se fazíamos, com muita dificuldade, papéis pequenos, quase sem fala, ou figurantes ao fundo? Como estaríamos preparados para viver, por exemplo, um protagonista ou outra personagem de destaque nas tramas quando a oportunidade surgisse?

Assim começamos a fazer contato com esses artistas, sugerindo que nos convidassem para algum teste. Eu indicava os atores do grupo, pois não era meu interesse que o elenco trabalhasse apenas no grupo Cabeça Feita. Queria que tivessem experiências em outras linguagens, que pudessem enriquecer sua formação.

O trabalho cênico é como qualquer outro: quanto mais trabalho qualificado, 
melhor o trabalhador. A experiência conta muito nesse ofício. Nesse sentido, pensamos que o grupo Cabeça Feita deveria ser um ótimo espaço para treino e prática. Com o tempo, alguns criadores da cidade, produtores, diretores, começaram a me ligar para pedir indicação de atores negros, pois diziam sempre não conhecer nenhum. $\mathrm{O}$ grupo mandava atores para testes de publicidade, filmes e outras produções cênicas. Começamos a ser referência na cidade.

Eu também aproveitava essas oportunidades para o diálogo com os criadores no sentido de sugerir, quando possível, reflexões sobre a construção das personagens, a desumanização delas, a persistência do olhar racista e dos estereótipos. Sugeria autores negros, indicava produções, quem sabe eles não começariam a nos enxergar a partir de outros pontos de vista? Entretanto, com o tempo, percebi que, por mais bem-intencionados, abertos ao diálogo, eles não tinham sido formados a partir dessa perspectiva. Era difícil enxergar os estereótipos e as ausências em uma sociedade criada, na maioria das vezes, para nos aceitar em condições de subalternização.

Durante a trilha da Cia de Arte Negra Cabeça Feita, vários foram os percalços enfrentados. Dificuldade de encontrar espaços para reuniões e ensaios porque nunca tivemos sede fixa. Dificuldade para manter os atores por falta de recursos financeiros e melhores condições de trabalho. Perdi atores excelentes por não poder oferecer condições para a atividade profissional, devido à falta de dinheiro e de patrocinadores. Muitas vezes, os atores saíam até mesmo por encontrar um emprego em outra área de atuação. Não é fácil sobreviver como artista em um país que não valoriza a cultura e seus trabalhadores. Para muitos, o ofício de teatro ainda não é considerado uma profissão.

Recebíamos muitos convites para apresentações, mas a maioria dos contratantes não estava disposta a pagar pelos serviços, considerando que nossa arte engajada não precisava de recursos materiais para sua subsistência. Mais que isso, observávamos que outros artistas eram contratados com altos cachês, principalmente aqueles que já tiveram alguma passagem pelas redes televisivas. O grande engolia o pequeno, que sobrevivia à míngua.

As questões do nosso teatro experimental também dificultavam o êxito. Nossa marca sempre foi a de um teatro reflexivo, justamente em uma cidade marcada pela comédia. Os grupos que enchiam teatros na cidade eram majoritariamente do gênero besteirol, com textos humorísticos, piadas, temas leves e de fácil digestão.

Na Cia de Arte Negra Cabeça Feira, não ocupávamos a cena para reforçar estereótipos do negro e da negra que tiram o riso fácil da plateia. Talvez as pessoas não estivessem acostumadas a encontrar atores negros em uma cena habitualmente embranquecida, principalmente ocupando esses espaços com outras perspectivas estéticas e de 
interpretação, de construção de personagens.

Ao longo do tempo, tivemos vários elencos. Alguns atores deixaram a companhia devido aos embates raciais, porque nunca foi fácil remexer um caldeirão quente como o do racismo - isso afetava a todos nós. Havia também a dificuldade de lidar com o processo de transformação decorrente da afirmação da identidade negra. A profissão de ator é desvalorizada por si só, imaginem um ator negro que insiste em falar sobre a identidade negra em um país com sérias áreas de conflito e tensões raciais.

Havia também a dureza do meio teatral, onde muitas vezes não éramos bemvindos. Era cansativo ter que explicar o tempo todo por que um teatro negro, e também havia a indiferença daqueles que achavam que teatro negro não era teatro. Não é fácil ser negro no Brasil. Não é fácil ser artista negro no Brasil. Mas é maravilhoso.

Não fui exitosa em todos os momentos, nunca tive essa expectativa, não é fácil governar cabeças, não é fácil estar à frente de um coletivo formado por essa gente tão especial, tão sensível e motivada como é essa gente de teatro. Faria tudo novamente. Hoje, mais madura, estou mais preparada, mais consciente do meu papel como artista e formadora.

Vários foram os momentos de êxito da companhia. Realização de temporadas, participação ativa do público, ricos debates, a alegria de estar em cena, de compartilhar o palco com outros atores, a sensação incrível da primeira viagem internacional em temporada teatral de um texto escrito e produzido por nós, a satisfação de receber uma remuneração digna como reconhecimento do nosso trabalho.

Várias foram as portas abertas pelo ofício teatral, as artes cênicas mudaram os cenários de realidade de muitos integrantes. Recebemos críticas, sim, mas também recebemos o reconhecimento e o respeito de outros companheiros da cena teatral e de artistas da cidade.

Ao longo da minha carreira, não conheci muitas diretoras de teatro, isso também é importante destacar. O espaço da direção teatral é majoritariamente masculino, como a maioria dos espaços de poder do país, por isso fico feliz pela ocupação desse espaço como mulher negra e artista.

Alguns desistiram do grupo por razões pessoais. Outros fortaleceram sua identidade teatral no grupo, mas escolheram outras possibilidades cênicas. Decisões, trajetórias, tudo isso faz parte da experiência humana.

Eu continuo pulsando teatro negro, não posso me separar das minhas certezas. Faço performances, recitais, ainda sou Cabeça Feita. Não sei se quero ser líder de um grupo de teatro negro. Mas quero, sim, fazer teatro negro.

Trecho do poema "Fratricídio": 


\author{
Sou negra \\ Meus dentes brancos trituram qualquer privilégio retinto \\ Meu sangue negro corrói a hipocrisia parda \\ Mela o mito da democracia racial \\ Corre maratonas libertárias negrófilas \\ Rasga as entranhas e reluz \\ Das cinzas à fênix \\ No fundo do olho há uma verdade viva \\ Muito além da cor.
}

SOBRAL, 2011, p. 72.

Questionar e refletir sobre o teatro negro revigorou minha experiência como atriz, como diretora de uma companhia teatral, ampliou os conhecimentos e me permitiu viver experiências memoráveis. Precisava olhar para dentro, parar e revisitar as entranhas. Um olhar distanciado e reflexivo sobre minha caminhada como artista e como líder de um coletivo, um olhar para o coletivo. Esse exercício adensou minhas certezas e aumentou as forças para a continuidade das minhas ações. Há muito a dizer. Muitos silêncios a revelar e questionar. Deixar de falar de nós é deixar de falar dos nossos bisavós, dos avós, dos pais. É deixar de produzir ruídos para os ouvidos daqueles que ainda virão.

A criação parte de urgências. Sem urgências não há nada. O teatro negro foi se materializando diante dos meus olhos cada vez mais escuro, com tons de negro explícitos, se assim consigo exprimir o fenômeno de revitalização depois de pensar tão profundamente sobre o teatro que vivemos, o teatro que fazemos e ainda faremos.

Pensar sobre a essência do teatro e suas especificidades foi fundamental para entender que o teatro negro é essencialmente teatro. Está na raiz da oralidade e da concepção de um tempo africano e ancestral, tempo vivenciado no espaço da cena em um fluxo diferente do fluxo do tempo nos nossos dias.

O espaço da cena negra também tem sua especificidade, tendendo à circularidade, ao encontro da coletividade, ao compartilhamento das ações e ao ritual, ao espaço sagrado. É o tempo dos griots, contadores de histórias, mestres responsáveis pela salvaguarda das tradições africanas.

Finalmente, importa destacar também o processo de criação do espetáculo Esperando Zumbi, cujo trecho foi apresentado na disciplina "Entre realidades e ficções teatro, cinema e suas encenações", oferecida pela Professora Dra. Roberta Matsumoto, no Programa de Pós-Graduação em Arte do Instituto de Artes da Universidade de Brasília, no 
primeiro semestre de 2014.

No decorrer da disciplina, um dos trabalhos apresentados seria a criação e apresentação de uma performance cênica. Decidi realizar uma performance com livre adaptação do texto teatral Esperando Godot, de Samuel Beckett. Rebatizado - Esperando Zumbi-, produzi um manifesto sensível a partir de um ponto de vista feminino e negro.

$\mathrm{Na}$ dramaturgia, uma mulher negra, de nome Massuena, espera ansiosamente seu homem diante dos paradoxos da construção e desconstrução da sua identidade negra e feminina. É uma personagem cheia de contradições, dilacerando o público com a contundência de algumas imagens que falam mais do que mil palavras.

No exercício angustiante da espera interminável, Massuena tenta reconstruir sua identidade negra diante dos fragmentos de uma diáspora estilhaçada.

Com esse exercício em sala de aula, pude pensar profundamente sobre a especificidade do teatro negro. As relações entre brancos e negros estavam presentes no espetáculo. Que negro é esse que se constitui a partir do olhar do branco colonizador? De acordo com o pensamento de Fanon (2008),

O negro tem duas dimensões. Uma com seu semelhante e outra com o branco. Um negro comporta-se diferentemente com o negro e com o branco. Não há dúvida de que esta cissiparidade é uma consequência direta da aventura colonial (FANON, 2008, p. 33).

O espetáculo abordou essas contradições, os paradoxos das relações inter-raciais a partir do ponto de vista de uma mulher negra. $\mathrm{O}$ trabalho começou a ser concebido em meio a um universo de leituras, discussões e reflexões do mestrado.

Justamente em um momento delicado do grupo, de poucos trabalhos, poucos integrantes, tempo de dedicação à pesquisa, a mulher criadora que sou começou a renascer após o processo de reflexão sobre sua trajetória, desde a fundação da Cia de Arte Negra Cabeça Feita, ressurgindo diante da crise, do tempo, das escolhas, do aprendizado, do fortalecimento do sentido da luta.

\section{A encenação}

Esperando Zumbi nasce gritando, sufocado, procurando libertação, pois a primeira imagem em cena é de uma mulher negra rompendo um saco plástico preto que está em sua cabeça. A fêmea vive um momento de sufocamento insuportável. Massuena consegue romper 
o saco preto, sai meio confusa ainda e começa a recordar que está ali à espera de alguém.

À primeira vista, parece uma mulher meio deslocada, não veste roupas ditadas pela moda, não tem um cabelo segundo os padrões, a cor da pele não está na maioria das capas de revistas. Mas a protagonista é vaidosa, quer se arrumar e se acha linda, porque tem um encontro. Queria destacar mais ainda a sua negritude, gosta de ser negra, mas não sabe trançar os cabelos, não sabe manejar os apetrechos étnicos que contribuem para a afirmação da sua identidade.

Massuena divide com a plateia a angústia da espera, a ilusão do final feliz, quer saber se alguém viu um homem negro por ali, pergunta repetidas vezes, com insistência. Ela tem certeza de que ele vem, mas ninguém viu. Massuena insiste, dizendo que o encontro foi marcado, tem fé e por isso vai esperar. Na ausência, começa a dizer em voz alta uma série de pensamentos aleatórios que surgem, especulações sobre o motivo da ausência. Agora a plateia sabe que ela espera Zumbi.

A mulher pensa em várias explicações para a sua ausência:

- Zumbi não veio porque foi abduzido, assim como 99\% dos homens negros que foram aliciados pelas mulheres brancas;

- Zumbi não veio porque entrou na geração fast-food, comeu demais, engordou e poderia estar com medo de aparecer disforme;

- Zumbi não veio porque não deseja passar um dia em um país tão racista como o Brasil.

O tempo passa e a espera vai ficando cada vez mais insustentável. A mulher tenta se enganar, mas percebe-se que não está bem, demasiado ansiosa, meio fora de si, gestos nervosos... É possível que Massuena pareça louca aos olhos do espectador, que muitas vezes poderá rir mesmo nos instantes mais dramáticos, em função da expectativa do público que não é atendida porque a mulher que está em cena não é nem de longe o estereótipo de mulher que a plateia espera quando pensa em alguém que ama e espera o ser amado, um herói, um homem de honra. Segundo o espelho da maioria dos espectadores que não ouviram ao longo da vida muitas histórias de amor vividas por personagens negras no plano da ficção, a atriz que interpreta a mulher parece não ser talhada para o ato amoroso, especialmente o amor romântico.

As pessoas fora do palco consideram ridícula a situação. A qualidade do riso demonstra isso. É uma reação esperada pela dramaturga e atriz, que deseja afetar o espectador de forma que ele reflita e possa perceber, a partir do momento que começa a se identificar 
com a humanidade da personagem, o racismo e o preconceito presente em nossa sociedade.

Talvez essa sensação não seja tão confortável, o público poderá tossir, sair no meio da apresentação, rir, a partir da reflexão, após ter sido afetado inesperadamente, no sentido de até mesmo começar a torcer pela protagonista, de forma nervosa.

No desespero, a mulher insiste que Zumbi é um homem de palavra, então poderia ter sofrido algum acidente, ter esbarrado com algum capitão-do-mato na casa-grande capitalista de nossos tempos e por isso ainda não teria conseguido aparecer, mas ele viria. Ela tenta se convencer, mas vai perdendo argumentos, chora copiosamente, emite gargalhadas nervosas em uma espiral crescente, agita o corpo e as mãos.

Finalmente, Massuena pega na cadeira onde esteve durante a maior parte da performance um tecido vermelho-sangue, sobre o qual esteve sentada, aperta o lenço na altura do sexo e segue em desespero, chora de dor e solidão, cada vez maior, mais pungente. $\mathrm{O}$ tecido vai descendo pelas pernas.

Espera-se que o público esteja tão concentrado na ação que não poderá perceber que ela está dando à luz. Nasce um menino. Seu choro, interpretado pela atriz, é avassalador. Com a nova vida, Massuena está em êxtase, encontra outros significados em sua estrada, se renova e percebe que não tem sentido esperar mais qualquer Zumbi, ela sempre esteve ali, pode e deve ser Zumbi, empoderando-se do seu legado e realizando as mudanças que gostaria de ver no seu mundo. Como se estivesse em um transe ritual, afirma:

Zumbi está aqui, eu sou Zumbi, Zumbi vive! Zumbi vive! Eu sou Zumbi! Vai falando enquanto levanta o bebê no alto da cabeça, o corpo todo em posição e expressão de vitória. Ela abraça o filho com alegria profunda, finalmente alcança a sua autorrealização, finalmente está pronta para seguir o seu caminho.Vai saindo da sala, caminhando com passos lentos e marcados.

Enfim, os pontos apresentados na plenária final do IV Fórum Nacional de Performance Negra, realizado em Salvador, em dezembro de 2015, contemplam os nossos achados sobre o Teatro Negro. Gostaria de destacar a minha concordância com os tópicos listados.

Afirmo que o teatro negro brasileiro não pode se apartar totalmente do teatro dito eurocêntrico nem das matrizes indígenas, uma vez que europeus, negros africanos e índios formam a matriz do povo brasileiro.

Tudo isso nos constitui. Entretanto, esse encontro de povos não aconteceu de forma romântica, consentida e também não foi um encontro marcado. Afirmamos nossa 
negritude para sobreviver diante de todas as estratégias de apagamento das referências negras e indígenas. Quando é que a luz desses excluídos será acesa? Temos muita história para contar. Por isso elegemos um espaço de criação, de resistência e sobrevivência. É desafiador construir um teatro que tenha nossa cara, que represente a nossa história, que preserve as nossas raízes. 


\section{CONSIDERAÇÕES FINAIS - RASURAS NO CÂNONE}

\section{Com o verbo na carne}

Esse texto deve ser aberto com bisturi

Para refletir sonhos alheios

Nas palavras, deixarei pistas de salvação

Letras a abrir caminhos

Sílabas de decisão

Esse texto deve ser aberto com bisturi

$\mathrm{O}$ verbo cheio de carne vai derramar sangue negro em seu rosto

Suas mãos brancas serão salpicadas de um vermelho quente e vivo

Nas palavras deixarei pistas de salvação

Esse texto deve ser aberto sobre a mesa

Para que reflita toda a sua luz

Depois, que seja oferecido

como o melhor tecido da última estação

Valorizado como pérola

Nunca distribuído aos porcos

Depois da refeição.

SOBRAL, 2014, p. 35.

Em novembro de 2016, a Cia de Arte Negra Cabeça Feita completa dezessete anos. Tempo dedicado ao fazer teatral, ao teatro negro, na teoria e na prática. Desde que comecei a graduação em Interpretação Teatral, na Universidade de Brasília, já se passaram vinte e cinco anos de atuação ininterrupta. Desde o primeiro curso de teatro profissionalizante no Rio de Janeiro, em 1986, são trinta anos dedicados ao teatro. Dá para contar com alegria o número de montagens, os diversos trabalhos, a experiência docente, os prêmios recebidos, dá para rememorar os artistas que passaram pela companhia.

O tempo sempre traz suas marcas. Também fazem parte da nossa trajetória os fracassos, os percalços, a cena esvaziada, os lapsos de tempo, os poucos integrantes na formação atual, a dificuldade de manter um grupo de teatro no Brasil, a sensação de estar sempre recomeçando, a falta de reconhecimento entre os nossos pares, a difícil arte das relações interpessoais.

$\mathrm{Na}$ carreira, muito vivi, além dos cenários imaginados quando, ainda menina, sonhava com os passos ensaiados no palco. O teatro sempre me levou mais adiante. Conheci lugares diferentes, cidades, culturas, pude conhecer e reconhecer a mim mesma e forjar a identidade artística. 
No início desta pesquisa, a maior inquietação apontava para o desejo de responder à seguinte pergunta: existe um teatro negro? Seria possível produzir um verbete para demarcar a sua existência conceituando a expressão? Essa pergunta foi o primeiro passo da caminhada, a força motriz do presente trabalho. Queria produzir rasuras no cânone. Tinha um imenso desejo de nomear, descrever, elencar as especificidades da estética no teatro negro brasileiro.

Não foi fácil delimitar um campo temático que pudesse delinear o objeto deste trabalho. O teatro negro ocupava um espaço bem maior do que o espaço de exclusão histórica demarcado para os artistas negros. Havia muito a dizer sobre ele, muitos nomes a citar, muitos espetáculos a descrever, textos teatrais para analisar, teóricos a consultar.

Era preciso delimitar um campo de pesquisa, aplacar meu desejo de gritar minhas descobertas aos quatro ventos. Uma pesquisa de dissertação não muda realidades, mas pode provocar algumas rasuras nos padrões estabelecidos, dar voz e visibilidade à temática pouco presente no espaço acadêmico.

Queria falar sobre o teatro negro. Precisava refletir sobre a questão, inclusive, porque sentia essa necessidade para o fortalecimento da atividade teatral na Cia de Arte Negra Cabeça Feita. Como pesquisadora, tinha interesse em teorizar e discorrer sobre o tema, até porque considerava que esse estudo fortaleceria os alicerces da minha prática cênica. Afirmar o teatro negro era afirmar a existência, demarcar um território, uma zona de criação especificamente preparada para abrigar nossas medidas de sonho.

Até aqui, considerando a trajetória da Cia Cabeça Feita, fomos questionados inúmeras vezes sobre nossa opção de montar um grupo formado exclusivamente por artistas negros, mas, por outro lado, poucos consideraram a realidade que apontava e ainda aponta para uma ausência ou escassez de artistas negros na maioria dos grupos teatrais da cidade.

O grupo recebeu muitos atores e atrizes em diferentes períodos. Os artistas que chegavam à companhia muitas vezes apareciam motivados pelo desejo de atuar, curiosos em relação à especificidade do trabalho realizado no grupo. Muitos deles tiveram a descoberta da sua negritude em nosso meio, afirmaram e firmaram sua identidade nos exercícios cênicos, nas discussões e nas leituras. Fico feliz por constatar que muitos deles, hoje atuando em outros grupos ou individualmente, ocuparam e ainda ocupam um espaço significativo na cena teatral da cidade.

Para nós, a negritude nunca foi modismo, nem objeto exótico de apropriação e comercialização na indústria cultural. Nossa identidade sempre esteve em nossas práticas vitais. Falar de negritude sempre foi uma forma de afirmar uma filosofia de vida. A escritura negra no campo das artes cênicas, essa que estamos produzindo ao longo dos anos, representa 
quem somos, confirma nossa existência, além dos rótulos, do exotismo, de qualquer tentativa de folclorização, falar de negritude é lutar por uma humanidade mais humana.

Percebi que os questionamentos estéticos mexiam com a autoestima dos artistas do nosso grupo. Era preciso encontrar argumentos para fortalecer e justificar nossas escolhas, mas não queria oferecer respostas e, sim, fomentar o debate para que juntos pudéssemos encontrar caminhos. A todo momento, recordava que o grupo tinha o nome Cabeça Feita porque privilegiava a consciência, a reflexão, o pensamento crítico, pois sempre acreditei na autonomia de pensamento indispensável na criação artística. Para fazer teatro, é preciso ter algo de significativo a dizer.

Mas onde encontrar outros grupos, artistas que pudessem estar interessados nessa discussão? Em Brasília, nos idos dos anos 2000, eu não tinha conhecimento de nenhuma outra companhia de teatro negro. Também eram poucos os artistas negros na cena teatral da cidade.

Nesse sentido, o encontro com o movimento de artistas em torno do Fórum Nacional de Performance Negra foi divisor de águas. Participei das quatro edições do evento, ouvindo intelectuais negros, dialogando com os pares, participando de oficinas, assistindo a espetáculos teatrais que contribuíam para o assentamento, para a materialização das questões discutidas nos dias dos eventos.

No primeiro fórum, me senti como o patinho feio que encontra os cisnes e descobre sua identidade. Meu corpo cênico, aquele que muitas vezes não tinha a aparência necessária para vestir as personagens da dramaturgia "universal", cabia naquele espaço. Minha voz ecoava nas falas dos participantes. Não estava só diante do racismo. Encontrei outras pessoas com as mesmas situações de discriminação e, mais que isso, comecei a fortalecer meu discurso e a sonhar com outras dramaturgias, outras formas de escritura da experiência negra na cena teatral. Não havia interditos para nossa atividade teatral. Percebi que até mesmo as peças teatrais do citado contexto da "universalidade" também poderiam ser interpretadas a partir do nosso ponto de vista.

Lamentei não poder levar comigo outros integrantes do grupo. Mas procurei repassar o máximo que pude, propor vivências também no nosso cotidiano a partir das discussões e do aprendizado no evento. A vivência com os artistas e grupos de teatro negro fortaleceu e ampliou as fronteiras da minha identidade como mulher, atriz, diretora teatral, escritora. Foi muito bom estar entre os meus, compartilhando criações, estratégias de enfrentamento diante das nossas dificuldades.

As questões da presente pesquisa me levaram adiante, propiciaram mais que respostas, inúmeras descobertas e o amadurecimento da minha atividade teatral e literária. $\mathrm{O}$ 
estudo e a consequente reflexão me levaram ao encontro de diversas experiências estéticas realizadas por artistas independentes e grupos radicados nos quatro cantos deste país, produzindo a despeito da escassez de recursos financeiros, da dificuldade de acesso aos meios de produção, profissionalizando seus coletivos, apetrechando seus núcleos de pesquisa no âmbito do teatro negro e das danças afro-brasileiras.

Existem muitos teatros negros. Podem estar invisíveis aos olhos da maioria, mas aos poucos vão invadindo a cena cênica eurocêntrica predominante. Com esse estudo, descobri mais que um teatro negro e uma estética negra na cena, inúmeros modos de fazer característicos dos teatros negros, considerando o amplo espectro relacionado ao universo da negritude. As técnicas teatrais apreendidas durante minha formação acadêmica em interpretação teatral, as leituras, os exercícios cênicos, as vivências, todo esse material poderia e deveria ser incorporado no contexto das nossas produções.

Ao contrário do que muitos afirmavam, quando decidi fazer teatro negro, não estava apartando a estética em detrimento do discurso político e engajado. Estava ingressando ainda mais fundo no campo do teatro, minha opção de vida e carreira, e inscrevendo no espaço das artes cênicas um caminho artístico totalmente apoiado na estética do discurso. Sempre me interessei pela linguagem teatral. É nela que inscrevo meu discurso, manejando suas técnicas e produzindo poéticas para a cena. No teatro negro, fortaleci minhas certezas com o objetivo de afetar o público, provocar um universo de imagens e sensações no espectador e praticar a arte teatral, com sua excelência, no sentido de refletir a experiência humana.

O teatro é um espelho, não uma caricatura. Constituir um teatro nacional, diante do imperialismo estético que considera a brancura como um cânone absoluto de beleza, quando, na verdade, ele é um entre outros, longe de qualquer pretexto contra a brancura, exige um entendimento multidisciplinar da nossa história e, principalmente, da diversidade que caracteriza sobremaneira a expressão artística brasileira.

Teatros negros são espaços de representação do jeito de ser e de viver da população negra deste país, locais de empoderamento do artista negro que pode atuar como sujeito e não como objeto da encenação. A cena é moldada para atender e reproduzir a experiência negra. Teatros negros são teatros universais, no sentido da pluralidade, porque abrangem tanta coisa!

Esse pode ser um dos sentidos da universalidade, que não deve propagar um molde para todos, sem incluir as diversidades; nesse sentido, é impensável que o teatro negro não seja estudado no contexto do teatro "universal". 
Teatros negros são lugares de conflito por excelência, onde a negritude é desafiada, provocada ao extremo, são ambientes de catarse, de distanciamento, de subversão das acepções de subalternidade histórica relegada aos negros deste país. Teatros negros são esses que estamos produzindo, éticos, estéticos, políticos e engajados. Espaços de resistência, quilombos da memória guardiã da ancestralidade.

Continuo firme no desejo de produzir teatros negros. Sigo impulsionada primordialmente pela necessidade de teatrar diante da reflexão sobre a experiência de ser negra em uma nação multiétnica e multicultural, além dos maniqueísmos de mal e bem, de forma a produzir falas que contemplem a nossa humanidade.

Sou formadora, dramaturga, atriz, diretora e intérprete da Cia de Arte Negra Cabeça Feita. Uma mulher de teatro, crescida e criada no meio das artes cênicas. Fui atrás dos sonhos de infância. Encontrei significados fundamentais para a atividade artística. Produzi, sim, algumas rasuras no cânone e pude reescrever a minha história de opressão e exclusão por meio da atividade teatral.

A pesquisa não finda; pelo contrário, move a roda do círculo que nos levará mais adiante em nossos saberes e ofícios. Espero que as preciosas luzes encontradas neste estudo sejam ofertadas à sociedade. Espero ansiosa pelo público depois do terceiro sinal. Desce o pano, urge o debate. 


\section{REFERÊNCIAS}

AFOLABI, Niyi. A visão mítico-trágica na dramaturgia abdiasiana. Revista Hispania, Espanha, vol. 81, n. 3, p. 530-540, 1998.

ARAÚJO, Joel Zito. A negação do Brasil. São Paulo: Editora Senac, 2000.

BARBOSA, Márcio. Frente Negra Brasileira. Depoimentos. São Paulo: Ed. Quilombhoje, 2007.

BARROS, Orlando de. Corações de Chocolat: A História da Companhia Negra de Revistas (1926-27). 1. ed. Rio de Janeiro: Ed. Livre Expressão, 2005.

BASTIDE, Roger. Sociologia do Teatro Negro Brasileiro. In: QUEIROZ, Maria Isaura Pereira. (Org.). Roger Bastide: sociologia. São Paulo: Ática, 1983.

BERND, Zilá. O que é negritude? São Paulo: Brasiliense, 1988.

BLOG DO VILA. Ator Jorge Washington é homenageado com Medalha Zumbi dos Palmares. Disponível em: <http://blogdovila.blogspot.com.br/2011/10/ator-jorge-washington-ehomenageado-com.html>. Acesso em: 15 mar. 2016.

BOAL, Augusto. Teatro do oprimido e outras poéticas políticas. 4. ed. Rio de Janeiro: Civilização Brasileira, 1983.

BRITO, Deise de. Othelo, o grande revisteiro do teatro brasileiro. Disponível em: $<$ http://www.yumpu.com/pt/document/view/40913979/otelo-o-grande-revisteiro-do-teatrobrasileiro-deise-de-brito-escola-/2>. Acesso em: 16 ago. 2016.

CASTRO, Ruy. O anjo pornográfico: a vida de Nelson Rodrigues. São Paulo: Cia das Letras, 2007.

CINE CLUBE MÁRIO GUSMÃO. Odu [documentário sobre Mário Gusmão]. Disponível em: 〈https://vimeo.com/140473204>. Acesso em: 16 ago. 2016.

COSTA, Haroldo. O negro nas artes cênicas. História do negro no Brasil, Brasília, v. 1, p. 205-261, 2004.

CUTI, Luís Silva. Dois nós na noite e outras peças de teatro negro-brasileiro. 2. ed. Belo Horizonte: Mazza Edições, 2009.

DOMINGUES, Petrônio. A crisálida do teatro negro no Brasil. Disponível em: <http://www.palmares.gov.br/sites/000/2/download/revista3/revista3-52.pdf>. Acesso em: 4 jan. 2016.

Movimento da negritude: uma breve reconstrução histórica. Mediações. Revista de Ciências Sociais, Londrina, v. 10, n.1, p. 25-40, jan.-jun 2005. Disponível em: <http://www.uel.br/revistas/uel/index.php/mediacoes/article/viewFile/2137/2707>. Acesso em: 2 jan. 2016. 
DOUXAMI, Christine. Teatro Negro: a realidade de um sonho sem sono. Afro-Ásia, Bahia, n. 25-26, p. 313-363, 2001.

A especificidade do teatro negro: nem religião, nem folclore, mas teatro, sim! In:

Cadernos do JIPE - CIT: Grupo Interdisciplinar de Pesquisa e Extensão em

Contemporaneidade, Imaginário e Teatralidade. Universidade Federal da Bahia. Escola de

Teatro, Programa de Pós-graduação em Artes Cênicas, n. 1, nov. 1998.

FANON, Frantz. Os condenados da terra. 2. ed. Rio de Janeiro: Civilização Brasileira, 1979.

Pele negra, máscaras brancas. Salvador: EDUFBA, 2008.

FARIA, João Roberto. História do teatro brasileiro. Das Origens ao teatro profissional da primeira metade do século XX. V. 1. São Paulo: Perspectiva, 2012.

FERNANDES, Florestan. O negro no mundo dos brancos. São Paulo: Difel, 1972.

FERNANDES, Florestan; PEREIRA, João Baptista Borges; NOGUEIRA, Oracy. A questão racial brasileira vista por três professores. Revista USP, São Paulo, n. 68, p. 168-169, 2005-2006.

Disponível em: <http://www.usp.br/revistausp/68/14-florestan-joao-oracy.pdf >. Acesso em: 5 jan. 2016.

FRANCISCO, Dalmir. Comunicação, identidade cultural e racismo. In: FONSECA, Maria Nazareth Soares. (Org.). Brasil afro-brasileiro. Belo Horizonte: Autêntica, 2006.

FREYRE, Gilberto. Casa-grande \& senzala: formação da família brasileira sob o regime da economia patriarcal. 23. ed. Rio de Janeiro: José Olympio, 1984.

GARCIA, Januário. 25 anos - Movimento Negro no Brasil. 2. ed. Brasília: Fundação Cultural Palmares, 2008.

GEERTZ, Clifford. A arte como um sistema cultural. O saber local. Petrópolis: Vozes, 2000, p. 142-181.

GOMES, Nilma Lino. Alguns termos e conceitos presentes no debate sobre relações raciais no Brasil: uma breve discussão. In: Educação anti-racista: caminhos abertos pela Lei Federal 10.639/03. Brasília: Ministério da Educação, Secretaria de Educação Continuada, Alfabetização e Diversidade, 2005.

HALL, Stuart. Da diáspora: identidades e mediações culturais. Organização Liv Sovik. Tradução Adelaine La Guardia Resende et al. Belo Horizonte: Editora UFMG; Brasília: Representação da UNESCO no Brasil, 2003.

JESUS, Jaqueline de et al. O que é racismo. Lisboa: Escolar Editora, 2014.

JOAQUIM, Maria Salete. O papel da liderança religiosa feminina na construção da identidade negra. Rio Grande do Sul: Pallas; São Paulo: Educ, 2001.

JR, Nabor (ed.). Legítima Defesa. Uma Revista de Teatro Negro. São Paulo: Cia Os Crespos da Cooperativa Paulista de Teatro. Ano 1. Número 1. $2^{\circ}$ Semestre 2014. 
LIMA, Evani Tavares. Por uma história negra do teatro brasileiro. Urdimento, Florianópolis, v.1, n. 24, p. 92-104, julho de 2015. Disponível em:

<file:///C:/Users/Usuario/Downloads/6490-18992-1-PB.pdf>. Acesso em: 20 out. 2015.

LIMA, Mariângela Alves de. O teatro do negro no Brasil e nos Estados Unidos. Revista USP, São Paulo, n. 28, p. 257-260, Dezembro/Fevereiro 95/96. Disponível em:

<http://www.usp.br/revistausp/28/19-mariangela.pdf>. Acesso em: 10 set. 2015.

LOPES, Nei. Enciclopédia Brasileira da Diáspora Africana. São Paulo: Selo Negro, 2004.

MAGALDI, Sábato. Panorama do teatro brasileiro. São Paulo: Difusão Europeia do Livro, 1962.

MARTINS, Leda Maria. A cena em sombras. São Paulo: Perspectiva, 1995.

MELLO Gustavo; BAIRROS, Luiza. (Orgas). Anais do I Fórum Nacional de Performance Negra. Brasília: Fundação Cultural Palmares, 2005.

MELLO, Gustavo. (Org.). Anais do II Fórum Nacional de Performance Negra. Brasília: Fundação Cultural Palmares, 2006.

MENDES, Miriam Garcia. A personagem negra no teatro brasileiro. São Paulo: Ática, 1982. O negro e o teatro brasileiro. São Paulo: Hucitec, 1993.

MONGA, Célestin. Niilismo e negritude. Tradução Estela dos Santos Abreu. São Paulo: Martins Fontes, 2010.

MOURA, Roberto. Grande Othelo. Um Artista Genial. Rio de Janeiro: Ed. Relume Dumará, 1996.

MOURA, Christian Fernando dos Santos. O teatro experimental do negro - Estudo da personagem negra em duas peças encenadas (1947-1951).2008. 183 f. Dissertação (Mestrado) Instituto de Artes, Universidade Estadual Paulista Júlio de Mesquita Filho. São Paulo, 2008. Disponível em:

$<$ http://base.repositorio.unesp.br/bitstream/handle/11449/86877/moura_cfs_me_ia.pdf?sequen ce $=1>$. Acesso em: 21 set. 2015.

MÜLLER, Ricardo Gaspar. (Org.). Dionysos (número especial sobre o Teatro Experimental do Negro). Brasília: Minc/Fundacem, n. 28, 1988.

MUNANGA, Kabengele. Identidade, cidadania e democracia: algumas reflexões sobre os discursos anti-racistas no Brasil. In: SPINK, Mary Jane Paris. (Org.). A cidadania em construção: uma reflexão transdisciplinar. São Paulo: Cortez, 1994.

NASCIMENTO, Abdias. (org.). Dramas para negros e prólogo para brancos. Rio de Janeiro: Teatro Experimental do Negro, 1961.

Sortilégio (mistério negro). Rio de Janeiro: Teatro Experimental do Negro, 1961. 
. (Org.). Teatro Experimental do Negro: Testemunhos. Rio de Janeiro: Edições GDR, 1966. Disponível em:

$<$ http://issuu.com/institutopesquisaestudosafrobrasile/docs/livro_testemunhos_2\#embedKL]IF Gl>. Acesso em: 1 jul. 2015.

. (Org.). O genocídio do negro brasileiro: processo de um racismo mascarado. Rio de Janeiro: Rio de Janeiro, 1978.

Sortilégio II: mistério negro de Zumbi redivivo. Rio de Janeiro: Paz e Terra, 1979.

(Org.). O quilombismo. Brasília: Fundação Cultural Palmares, 2002.

OBJETO SIM. 7 x Rodas. Disponível em: <http://objetosim.com.br/7-x-rodas/>. Acesso em: 28 jun. 2016.

PAVIS, Patrice. Dicionário de teatro. Tradução J. Guinsburg e Maria Lúcia Pereira. São Paulo: Perspectiva, 1999.

PENNA, Martins. O juiz de paz na roça. Biblioteca da Universidade Federal de Uberlândia (UFU). Disponível em: <http://www.bdteatro.ufu.br/download.php?pid=TT00149>. Acesso em: 25 jun. 2016.

PRANDI, Reginaldo. O Brasil com axé: candomblé e umbanda no mercado religioso. Estudos Avançados, São Paulo, v. 18, n. 52, Sept./Dec. 2004. Disponível em:

<http://www.scielo.br/scielo.php?script=sci_arttext\&pid=S0103-40142004000300015>. Acesso em: 10 jun. 2016.

Mitologia dos orixás. São Paulo: Companhia das Letras, 2000.

POPPE, Mário. Tudo preto. Revista Fon-Fon, Rio de Janeiro, ano XX, n. 32, p. 35, 1926.

PROGRAMORI. Haroldo Costa fala sobre o grande ativista negro Abdias Nascimento. Disponível em: 〈https://www.youtube.com/watch?v=KUkIyGlcxRo〉. Acesso em: 9 out. 2015.

RAMOS, Alberto Guerreiro. Introdução crítica à sociologia brasileira. Rio de Janeiro: Editorial Andes Ltda., 1957.

RODRIGUES, Nelson. Anjo negro. Rio de Janeiro: Nova Fronteira, 2005.

ROMÃO, Jeruse. História da educação do negro e outras histórias. Brasília: Ministério da Educação, Secretaria de Educação Continuada, Alfabetização e Diversidade, 2005.

ROSA, D. R. A. Teatro Experimental do Negro: estratégia e ação. 2007, 174 p. Dissertação (Mestrado em Sociologia) - IFCH, Universidade Estadual de Campinas, Campinas, 2007.

RUFINO, Joel. O que é racismo? São Paulo: Ed. Brasiliense, 2005.

SANTOS, Inaycira Falcão dos. Corpo e ancestralidade. Uma proposta pluricultural de dança- 
arte-educação. 2. ed. São Paulo: Editora Terceira Margem, 2006.

SEMOG, Éle; NASCIMENTO, Abdias. Abdias do Nascimento: o griot e as muralhas. Rio de Janeiro: Pallas, 2006.

SHAKESPEARE, William. Romeu e Julieta. Tradução e introdução Barbara Heliodora. Ed. especial. Rio de Janeiro: Nova Fronteira, 2011.

SILVA, Ermínia. Circo-teatro: Benjamin de Oliveira e a teatralidade circense no Brasil. São Paulo: Ed. Altana, 2007.

SILVA, Nelson Inocêncio da. Culturas e imaginário: um ponto de vista negro. 2. ed. Brasília: Fundação Cultural Palmares, 2014.

SILVA JR, Paulo Melgaço da. Mercedez Baptista. A criação da identidade negra na dança. Brasília: Fundação Cultural Palmares, 2007.

SANTO, Spirito. A desqualificação da "Negra que dança" e a invenção da bunduda "Mulata que rebola". Disponível em: <https://spiritosanto.wordpress.com/2012/02/03/mercedesbatista-assim-dancou-a-desconstrucao-da-modernidade-na-danca-afro-do-brasil/>. Acesso em: 7 mar. 2016

SOBRAL, Cristiane. Não vou mais lavar os pratos. 2. ed. Brasília: Ed. Dulcina, 2011. Só por hoje vou deixar o meu cabelo em paz. Brasília: Ed. Teixeira, 2014.

STAMBERG JR. Companhia Negra de Revista: 85 anos passados “em branco". Disponível em: 〈http://ascoresdasruas.blogspot.com.br/2011/09/companhia-negra-de-revista-85-anos.html>. Acesso em: 28 dez. 2015.

THEODORO, Helena. Iansã. Rainha dos ventos e das tempestades. 1. ed. Rio de Janeiro: Ed. Pallas, 1989.

TV SENADO. Documentário resgata trajetória de Abdias do Nascimento. Disponível em: <https://www.youtube.com/watch?v=sYLzhTyqt2U>. Acesso em: 8 mar. 2016.

UZEL, Marcos. O teatro do bando, negro, baiano e popular. Rio de Janeiro: Ed. P555, 2003. 


\section{APÊNDICE - QUESTIONÁRIOS}

Questionário aplicado por ocasião do IV Fórum, em dezembro de 2015, em Salvador.

Alguns participantes responderam durante o evento, outros enviaram posteriormente por $e$ mail.

Total de questionários respondidos:

Grupos -13

Artistas independentes -02

Total -15

\section{Questionário 1}

Cássia Valle - Bando de Teatro Olodum - Salvador

1. Qual é seu nome, o nome do seu grupo, companhia ou outro agrupamento?

Cássia Valle. Bando de Teatro Olodum.

\section{O grupo tem quantos integrantes? Nomes? Formação artística?}

13 atores e 8 estagiários.

Colegiado: Cássia Valle, Fábio Santana, Jorge Washington, Ridson Reis e Valdinéia Soriano.

Direção musical: Jarbas Bittencourt.

Coreógrafo: Zebrinha.

Assistente de coreografia: Arismar Adoté Junior.

Iluminador: Rivaldo Rio.

Elenco: Arlete Dias, Cássia Valle, Elaine Nascimento, Ednaldo Muniz, Fábio Santana, Geremias Mendes, Jamile Alves, Jorge Washington, Leno Sacramento, Merry Batista, Rejane Maia, Ridson Reis, Sergio Laurentino, Valdinéia Soriano.

Atores estagiários: Deyse Ramos, Ed Firenza, Gabriel Nascimento - Lucas Leto, Naira da Hora, Renan Mota, Shirlei Sanjeva, Vinicius Carmezim.

Músicos: Cell Dantas, Daniel Vieira (Nine), Maurício Lourenço.

\section{Qual é a sua atividade no grupo?}

Atriz e produtora membro do colegiado que gere o grupo.

\section{Em que ano surgiu, em que cidade?}


O Bando de Teatro Olodum é a companhia negra de maior visibilidade na história das artes cênicas na Bahia e uma das mais conhecidas do país, fundado em 1990, na cidade de Salvador.

\section{Qual é a sua formação artística e ou acadêmica?}

Museóloga e assistente social.

\section{Qual é a linguagem artística desenvolvida pelo grupo?}

Teatro.

\section{Histórico do grupo, suas principais conquistas e dificuldades.}

São 25 anos de desafios novos a cada nova montagem, a cada novo projeto, tocar, dançar, cantar, fazer clássicos, Brecht, aprofundar os conhecimentos dos ritos, Büchner, Müller, usar novas tecnologias, Shakespeare, cinema, cordel, televisão, produzir, dialogar... E o desafio de sobreviver financeiramente. Os recursos do bando sempre vieram de seu trabalho, da bilheteria de apoios, de projetos de projetos desenvolvidos e de serviços prestados. Sempre dividimos o resultado financeiro de nossos esforços entre nós reservando uma parte para o grupo e, algumas das vezes o resultado da bilheteria de um espetáculo produziu outro. Dos 31 espetáculos que fizemos apenas dois foram patrocinados: Zumbi está vivo e continua lutando, Fundação Cultural do Estado da Bahia, e Ópera de três reais, pela Coelba. O deputado federal Luiz Alberto também nos apoiou, propondo emendas parlamentares para o Bando, inclusive o de SUS qualificação administrativa. O filme Ó paí ó! e a série televisiva trouxeram recursos financeiros e maior visibilidade midiática nacional ao Bando, 2008 veio o primeiro edital (Petrobras), antes concorremos a vários e perdemos vários com esses tivemos recursos por dois anos para desenvolver as ações continuadas do grupo: apresentações de repertório, ações formativas, pesquisa e montagem e resulta no espetáculo Bença, comemorando 20 anos do grupo, com ele comemoramos também o quarto prêmio Braskem de teatro baiano. O espetáculo tem grande visibilidade no cenário baiano e sempre gerou recursos que fizeram o grupo dar continuidade as suas atividades administrativas e formativas. Em 2014 ganhamos outro edital para desenvolver um projeto com uma carga horária mais abrangente resultando em três grandes mostras no palco do teatro Vila Velha e remontagem de dois espetáculos do grupo iniciando a comemoração dos 25 anos. Os espetáculos foram: Relato de uma guerra

que não acabou e Ó pai ó!. Em 2014, o grupo passar a ser gerido por um colegiado por atores escolhidos pelo grupo para gerenciar e produzir os seus projetos. Tendo Zebrinha, Chica Carelli e Jarbas Bittencourt fazendo parte do nosso conselho artístico. Em 2015, estreamos Erê, espetáculo que tem a direção de zebrinha e Fernanda Júlia. Com concepção de Lázaro Ramos e texto de Daniel Árcade, celebra a primeira parceria do Bando com o NATA. 


\section{O que é teatro negro ou dança negra na concepção do grupo?}

A discussão sobre dramaturgia negra vai além do embate da teatralidade. Enfrenta também as questões da representação da identidade negra no cenário nacional. O bando construiu e consolidou uma dramaturgia e estética próprias, tendo o negro e sua tradição socioculturais como matéria-prima de seus espetáculos.

\section{Quais são os referenciais teóricos ou práticos?}

O Bando tem como proposta uma linguagem contemporânea comprometida com um teatro engajado. Suas peças mesclam humor e discussão racial. Leveza e ironia, diversão e militância. Além da palavra os atores utilizam a dança e música, referencias rituais do candomblé e aprofundam-se bastante na fonte da cultura afro-brasileira. Como também tem influências da comédia Dellarte, Brecht e Abdias do Nascimento.

\section{Qual é a metodologia de trabalho do grupo?}

O nosso grande guia sempre foi à técnica da improvisação e construção coletiva dos textos da maioria dos espetáculos que fizemos começamos os nossos processos escolhendo os personagens através dos quais cada ator quer falar. Os personagens sempre são criados levando-se em conta que não serão nunca a representação de um ser psicológico, mas de um ser social. Foi a partir desta base que trabalhamos todos esses anos nossos temas surgem de observações reflexivas sobre o momento histórico que vivemos. Por exemplo. Em Ó pai ó! os atores e atrizes bateram na porta dos cortiços do Maciel -Pelourinho e foi para dentro das casas conhecerem a intimidade dos moradores e colher material para elaboração do texto. Além do problema de moradia, a peça (que inspirou um filme homônimo em 2007, ano que o Bando ganhou projeção nacional) tratou de outro tema dramático: o assassinato de crianças que dormiam nas ruas do centro histórico de Salvador e ficavam expostas às ações silenciosas de exterminadores durante a madrugada. Tudo sempre acompanhado da dança e música negra para a construção do corpo negro em cena. Dessa forma tem defendido um projeto de expressão coletiva de ideias e contribuído de forma significativa para o fortalecimento de temáticas sociais e políticas na vida cultural baiana em mais de duas décadas de existência Foi descobrindo como construir personagens que desenvolvemos nosso principal método. Outra linha marcante da nossa metodologia é a investigação das possibilidades dos elementos comuns aos ritos e dramaturgia dos terreiros para o palco, objetivando mais os problemas do homem com o homem e não a relação do homem com a divindade tem sistematizado esta transposição através de uma prática de longo prazo com a maioria dos integrantes que fundaram o grupo. 


\section{Quais são os achados estéticos, os achados da poética do grupo no que se refere à arte negra?}

Cada processo é um processo, o Bando sempre investiu na descoberta de novos caminhos e na própria diversidade do teatro. Vou exemplificar isso em quatro dos nossos momentos. Em 2006 investiu em Shakespeare criou um Sonho de uma noite de verão negro, repleto da matriz africana, sem trair o inglês em 2007, investiu no teatro para crianças, pela necessidade de criar referências negras positivas para as crianças negra e branca poderem ter imagens de fantasia, com personagens e estéticas e narrativas vindas das diversas culturas que também formaram nossa identidade, o resultado são novas Áfricas, que se desdobraram projetos educativos desenvolvidos nas escolas de Salvador e no palco do teatro Vila Velha. Em 2010 (depois de uma pesquisa de dois anos), com Bença, tempo, ancestralidade e os atores do bando, se encontram no palco, num espetáculo/instalação em que tecnologias e audiovisuais reconstruíam na cena o conceito do continum do tempo, como o entendem a cultura Bantu e outras tradições africanas. Em 2012, O Bando de Teatro Olodum busca se reinventar, de novo num diálogo multicultural com Takaishi Endo e Butô, o espírito dessas duas energias cria bando + butô. As duas identidades contaminadas uma pela outra. Essas novas maneiras de se dizer o mesmo é que faz o exercício estético sempre dinâmico, reinventando-se e aprimorando-se a cada novo espetáculo. Tentativas de encontrar novos suportes para fortalecer o mesmo discurso.

\section{O trabalho do grupo é político? Por quê?}

Sim, desde que surgiu em 1990, o bando firmou sua identidade negra e política nos palcos até então brancos da capital, impôs a realidade e estética da Bahia negra e excluída, bem diferente da exibida pelos cartões postais. Denunciou a discriminação racial. Satirizou as inter-relações sociais, polemizou, redefiniu critérios de encenação cada ação inegavelmente é uma ação política.

\section{Gostaria de acrescentar algo mais?}

O Bando de Teatro Olodum, nascido em uma cidade onde a raça negra constitui cerca de $80 \%$ da população tem como proposta uma linguagem contemporânea, comprometida com o teatro engajado, mas sempre a busca de encontrar novos suportes para o mesmo discurso. Tentativas de um grupo que procura mudar, aprender com os nossos mais velhos e, com o futuro, rever o presente, tentar resolver o presente para formular, as questões necessárias. Questiona o que é ter 25 anos sob o palco, ser negro e ter voz no seu dia a dia. 


\section{Questionário 2 \\ Hilton Cobra - Cia dos Comuns - RJ}

1. Qual é o seu nome, o nome do seu grupo, companhia ou outro agrupamento?

Hilton Cobra - Cia dos Comuns.

\section{O grupo tem quantos integrantes?}

7 integrantes: Anna Paula Black, Bruno Gomes, Cridemar Aquino, Duda Fonseca, Gabi Luiz, Sarito Rodrigues, Valéria Monã.

\section{Qual é a sua atividade no grupo?}

Diretor.

\section{Em que ano surgiu, em que cidade?}

Em 2001, no Rio de Janeiro.

\section{Qual é a sua formação artística e ou acadêmica?}

Os meus 40 anos de carreira. Aprendendo no "tapa", na vida teatral, sendo rato de teatro.

\section{Qual é a linguagem artística desenvolvida pelo grupo?}

Teatro.

\section{Faça um breve histórico do grupo, suas principais conquistas e dificuldades.}

Criada no Rio de Janeiro em 2001, pelo ator e diretor Hilton Cobra, a Cia dos Comuns é um grupo de teatro formado por atrizes e atores negros com a missão artística e política de desenvolver uma pesquisa teatral negra que possibilite um maior conhecimento da nossa cultura, além de estimular o apuro técnico e ampliação do espaço de atuação profissional de artistas e técnicos negros no mundo das artes cênicas. É responsável pela encenação dos espetáculos A Roda do Mundo, Bakulo - Os bem lembrados Candaces - A reconstrução do fogo e Silêncio. Também realiza projetos extra palco como o Seminário A Presença do Negro no Teatro Brasileiro; Fórum Nacional de Performance Negra (BA) - encontro de diretores de grupos de teatro e dança negros (em parceria com o Bando de Teatro Olodum/BA) e Olonadé - A cena negra brasileira (RJ), mostra de teatro e dança negros. No último mês de dezembro/2015 realizou o IV Fórum Nacional de Performance Negra, onde foi debatida e aprovada a criação da campanha "Cultura sem Racismo", que será lançada no dia 25 de maio, dia de África.

\section{Principais trabalhos:}

Workshop (2001) - O workshop Oficinas Paralelas foi criado para dar oportunidade e revelar o potencial dos atores e atrizes negros brasileiros, fornecendo, ao mesmo tempo, a base para formação do elenco e da equipe técnica da Cia dos Comuns; 
Seminário (2001) - O Seminário A Presença do negro no teatro brasileiro objetivou contextualizar e solidificar as bases estéticas e culturais para a criação da Cia dos Comuns, dentro de uma perspectiva histórica e social;

I Oficina Comuns de Dança Afro (2006) - Ministrada pelo coreógrafo Zebrinha, um dos mais importantes e experientes profissionais do mundo da dança brasileira. Durante uma semana, 49 artistas do teatro e da dança mergulharam e experimentaram o que a de mais moderno na dança afro-brasileira;

Olonadé - O Teatro da Comuns (2007) e Olonadé - A cena negra brasileira (2010-2011) Criar meios para a produção de um teatro e de uma dança a partir da perspectiva das culturas de matriz africana e capacitar profissionais nas artes cênicas, tendo como ênfase o teatro negro brasileiro. Estes foram os motivos que levaram a Comuns a realizar uma mostra de teatro e dança negra intitulada "Olonadé - O Teatro da Comuns e o Olonadé - A cena negra brasileira", compostos de palestras, debates, oficinas (dança, música de cena, teatro e figurino) e leituras dramatizadas e apresentações de espetáculos;

Fórum Nacional de Performance Negra (2005, 2006, 2009, 2015) - A Cia dos Comuns realiza, juntamente com o Bando de Teatro Olodum/BA, o Fórum Nacional De Performance Negra, em Salvador/BA. Desde a sua primeira edição, o fórum reuniu mais de 200 pessoas entre artistas, representantes de grupos e companhias de teatro e dança negros, pesquisadores e acadêmicos com o objetivo de discutir nossa dramaturgia negra e os mecanismos de financiamento capazes de dar conta da demanda da nossa produção artística. O evento é composto de palestras, mesas-redondas, debates, oficinas, grupos de trabalho, leituras dramatizadas e espetáculos de dança, teatro e manifestação cultural de matriz africana.

\section{Espetáculos:}

A roda do mundo (2001/ 2002) - Um espetáculo onde o jogo da capoeira é o fio condutor de histórias sobre a luta pela sobrevivência a partir das dificuldades da comunidade negra, dentro de uma estética onde o gesto, a dança e a música imprimem um significado especial à cena. Temporada: Rio de Janeiro e Salvador.

Candaces - a reconstrução do fogo (2003-2004) - Candaces - Shanakdakete, Amanirenas, Amanishakete, Amanitere - eram rainhas e guerreiras negras que viveram antes da Era Cristã, detendo o poder no Império Méroe. O espetáculo é um mergulho no universo feminino, destacando a riqueza, os percalços e os avanços que marcam a trajetória das mulheres negras e as contribuições políticas, culturais e sociais até a nossa época. Candaces ganhou o Prêmio Shell/2003 de Melhor Música, tendo sido indicado em mais 3 categorias: (Direção, Figurino e Coreografia). Eleito pelos Jornais "O Globo" e "Jornal do Brasil" como um dos 10 melhores 
espetáculos de 2003. Temporada: Rio de Janeiro, Brasília e Salvador. Fecha a turnê no Theatro Municipal do Rio de Janeiro com duas apresentações para 4.700 espectadores.

Bakulo - os bem lembrados (2005-2006) - Evocando mitos passados e com uma narrativa fortemente baseada no pensamento do Professor Milton Santos e sua obra Por uma outra globalização, Bakulo - os bem lembrados traz também aspectos da genialidade de Glauber Rocha na construção de um texto cuja força está na palavra e na discussão de temas como a ocupação dos territórios, exclusão social e políticas para negros, tudo dentro de uma contextualização inquietante, seca e direta - sem metáforas e mais realista.Com uma estética que valoriza a música - executada ao vivo por um quinteto acústico; Bakulo flerta com a linguagem do cinema a partir da construção de cenas que são apresentadas como um roteiro cinematográfico. "O espetáculo corre em quatro linhas que se cruzam e interagem entre si: o texto de Milton Santos; os personagens contemporâneos que falam através desse roteiro; os personagens ancestrais presentes ao longo da peça e a trilha musical harmonizando as situações retratadas no palco. Optamos por apresentar essas cenas de forma fragmentada, instigando o espectador a criar a sua própria edição" afirma Marcio Meirelles, diretor do espetáculo. Temporada: Rio de Janeiro, Curitiba, Brasília, Belo Horizonte e Salvador. Fecha a turnê no Theatro Municipal do Rio de Janeiro com uma apresentação para 2.350 espectadores. Silêncio (2007 a 2009) - Dirigido por Hilton Cobra, esse espetáculo traz como fio condutor o seguinte pensamento: "Qual o silêncio contido no corpo de uma pessoa que pensa que a qualquer momento do seu dia pode sofrer algum tipo de discriminação?” O espetáculo, inteiramente dançado, traz ao palco poesias de Cruz e Souza, textos construídos pelos atores e contribuições de Fernando Coelho Bahia e Cidinha da Silva. A loucura também é considerada durante todo o espetáculo, investigamos os processos de loucura e as sequelas deixadas pelo o racismo no universo psicológico de toda uma população de negros, entre eles crianças, homens e mulheres. Temporadas: Rio de Janeiro, Brasília, Recife, Salvador e Santo AmaroBA.

\section{Matérias:}

\section{LISTA DE INDICADOS AO PRÊMIO SHELL NÃO CONTEMPLA AUTOR peça sobre} cultura negra encabeça a lista, disputando quatro categorias.

Celebração da cultura negra em bela encenação

A peça "Candaces - A reconstrução do fogo" foi a que recebeu mais indicações do júri... O espetáculo concebido pela Cia dos Comuns, grupo que se dedica há vários anos à divulgação e à preservação da cultura negra, fez temporada nos teatros Glaucio Gill e Carlos Gomes e chamou a atenção da crítica para a bela encenação, que lhe rendeu indicações para direção 
(de Marcio Meirelles), figurino (de Biza Vianna), música (de Marcos Povoas e Puan Viana) e ainda categoria especial, pela coreografia de Zebrinha. (O Globo)

\section{OS MELHORES DE 2003 NO TEATRO}

CANDACES - A RECONSTRUÇÃO DO FOGO: A Cia dos Comuns, só com atores negros, reafirmou a sua qualidade estética com o espetáculo no Teatro Gláucio Gill. O grupo dirigido por Marcio Meirelles traçava um paralelo entre as Candaces, guerreiras negras que vieram antes da Era Cristã, e as mulheres negras de hoje. (O Globo)

\section{GRUPOS RENOVAM O TEATRO NO RIO}

A Cia dos Comuns, que desenvolve pesquisa em torno da negritude, impressionou em Candaces pela persistência de um projeto teatral com sólidos fundamentos culturais, que se concretizou numa montagem de exuberância rítmica, de coreografias ritualísticas e alguns acenos ao teatro de protesto. (Jornal do Brasil)

\section{Críticas:}

A roda do mundo

"Ha algumas décadas que o teatro não apresenta contestação tão violenta quanto a que aparece no espetáculo "A roda do mundo”, da Cia dos Comuns... O objetivo do grupo é trazer para o teatro brasileiro o universo do negro, "discutindo e propondo uma nova consciência que garanta seu crescimento pessoal, intelectual e profissional”. Dificilmente algum objetivo poderia ser mais digno de apoio e aplauso.

“(...) O conjunto do elenco atua com desenvoltura, dança bem e está obviamente engajado, $e$ de forma profunda com a mais que justa contestação..."

\section{Contestação no universo do negro - Bárbara Heliodora/O Globo}

Candaces - A reconstrução do fogo

("A encenação é uma bela apologia da dignidade da mulher negra, com um texto que mistura a evocação de histórias e mitos das ancestrais africanas e os problemas do cotidiano da comunidade negra, sua luta pela dignidade individual e de grupos em face das barreiras, dos preconceitos ostensivos ou sub-reptícios...”)

\section{Bela apologia da dignidade da mulher negra - Bárbara Heliodora/O Globo}


(“... os dois espetáculos (A Roda do Mundo - $1^{a}$ montagem da Cia dos Comuns e o atual “Candaces”)demonstram a qualidade do trabalho de pesquisa sobre manifestações culturais e suas ressonâncias contemporâneas, relacionadas com as dificuldades de afirmação numa sociedade excludente e preconceituosa...")

\section{A beleza e a força de Candaces - Macksen Luiz/Jornal do Brasil}

(“...não é sempre que se tem o privilégio de ver uma montagem que, além de irretocável do ponto de vista formal, lida com temas capazes de gerar uma emoção profunda... Bem escrito, contendo ótimos diálogos e personagens marcantes, o texto chega à cena em versão deslumbrante...")

\section{Cia dos Comuns realiza espetáculo imperdível - Lionel Fischer/Tribuna da Imprensa e Prêmio Shell de Teatro}

Bakulo - Os bem lembrados

"Se em Roda do Mundo se enfatiza a condição social do negro, num quadro expositivo, quase naturalista, e com caráter de denúncia, em Candaces remete-se ao divinal para estabelecer a construção mítica do mundo. Já Bakulo procura integrar os dois planos, com ênfase maior nas próprias dificuldades da comunidade negra em conviver com o preconceito e a exclusão. A perspectiva agora se desvia para as suas entranhas e vivências, o conflito na convivência da ascensão social com as origens."

\section{(A dramaturgia étnica da Companhia dos Comuns - Macksen Luiz / Jornal do Brasil)}

"Estruturado como um roteiro cinematográfico, o texto oferece à plateia um amplo painel das inquietações do negro no mundo globalizado...Outro ponto positivo é o distanciamento provocado pela leitura de textos sobre a pertinência de vários temas. E se a tudo isso somarmos a relevância do material dramatúrgico, chega-se à conclusão de que "Bakulo..." só poderia dar errado se a montagem e a atuação do elenco fossem catastróficas. Evidentemente, não é o caso, pois estamos falando de um dos melhores e mais sérios grupos teatrais do Rio".

(Bakulo "Os bem lembrados" Montagem impecável no Sesi - Lionel Fischer / Tribuna da Imprensa)

Silêncio

"Acessos de loucura eram expurgados através de uma coreografia marcada por batidas 
fortes, expressões corporais latentes, firmes e ditadas pelo som e pelo tom das palavras proferidas ou até mesmo expostas com um grito de dor sufocado. Elas partiam das vítimas de uma população que, ironicamente, não se afirma como preconceituosa, mas discrimina aqueles que são "diferentes". Silêncio busca provocar o espectador a pensar sobre a intolerância, sentimento que permeia todas as sociedades".

\section{(Intolerância é questionada pelo espetáculo Silêncio)}

\section{Bárbara Lacet/ Jornal do Comércio - Recife)}

\section{O que é teatro negro ou dança negra na concepção do grupo?}

O teatro tem posição destacada em todas as culturas, expressando visões de mundo, sentimentos, sonhos e desejos. Por sua vez, alimenta-se de mitos, lendas, costumes populares, estilos históricos de vida, além de assimilar todas as formas de arte. Nessa perspectiva, o teatro é a "expressão concentrada da cultura de um povo". Entretanto, a despeito desta relevante função social das artes cênicas - e do teatro em particular - existe uma lacuna na dramaturgia que chega aos nossos palcos. É paradoxal que no país que abriga a segunda maior população negra do mundo, e que evoca como símbolos de sua cultura a música, a dança e a culinária negras, o teatro ainda expresse de forma tão tímida a influência do negro na sociedade brasileira. Por isso, é fundamental criar os meios para que o teatro brasileiro seja capaz de dar conta de uma realidade mais total: mostrar o negro - e a sociedade, por consequência - discutindo-se, avaliando-se, ocupando lugar de dono de seu próprio destino, construindo uma nova consciência que garanta o seu crescimento pessoal, intelectual e profissional. Um teatro empenhado em recuperar a dignidade do negro, sem perder de vista o caráter multirracial da sociedade brasileira. E sem perder, sobretudo, a dimensão absolutamente dinâmica e integradora da cultura negra da diáspora. É através dessa perspectiva que a Comuns se propõe a criar mecanismos capazes de desenvolver trabalhos que abarquem uma cosmovisão artisticamente negra no âmbito das artes cênicas. Sem dúvida, um grande desafio, mas, sobretudo uma necessidade histórica e cultural.

\section{Quais são os referenciais teóricos ou práticos?}

Companhias como o TEN - Teatro Experimental do Negro, criado por Abdias do Nascimento, que revelou nomes como Ruth de Souza e Léa Garcia; o Teatro Popular Brasileiro, fundado por Solano Trindade; o Grupo Brasiliana, dirigido por Haroldo Costa e o Teatro Profissional do Negro, de Ubirajara Fidalgo. Sem esquecer de Benjamim de Oliveira, considerado o primeiro palhaço negro do mundo, ainda no século 19.Como também as companhias mais novas e resistentes como a Cia Étnica de Teatro e Dança, Cia Rubens \& 
Barbot, Cia Aérea de Dança, Cia Black\& Preto, Cia Nós do Morro, Teatro Profissional do Negro (TEPRON), Teatro de Anônimo, Cooperativa Abayomi, todas no Rio de Janeiro e, ainda, o Bando de Teatro Olodum, em Salvador, Cia SeráQ, Belo Horizonte entre outras.

10. Qual é a metodologia de trabalho do grupo?

Não respondida.

11. Quais são os achados estéticos, os achados da poética do grupo no que se refere à arte negra?

Não respondida.

12. O trabalho do grupo é político? Por quê?

Não respondida.

13. Gostaria de acrescentar algo mais?

Não respondida.

\section{Questionário 3}

\section{Cia. de Danças e Teatro Nego D’Água - Juazeiro - BA}

1. Qual é o seu nome, o nome do seu grupo, companhia ou outro agrupamento?

Cia. de Danças e Teatro Nego D’Água.

2. O grupo tem quantos integrantes? Nomes? Formação artística?

Coordenação:

Elson Campos: Ator DRT 3369-Arte educador, mestre clown- Coordenador Geral e diretor do núcleo de teatro;

Ioná Pereira: Atriz, dançarina e coreógrafa DRT 3370-Pedagoga, Teóloga-Pós-Graduanda em Dança Educacional e Artes Cênicas - Coordenadora e coreógrafa do núcleo de danças;

$\mathrm{M}^{\mathrm{a}}$ Laura Campos: Dançarina, atriz e produção.

Nossos elencos são sempre rotativos, pois assim oportunizamos a formação de muitos multiplicadores cada montagem nossa envolve muita pesquisa, debate e vivências que ajudam a formar para os palcos e para a vida.

\section{Qual é a sua atividade no grupo?}

Coordenadora e Coreografa do Núcleo de Danças.

4. Em que ano surgiu, em que cidade?

Em 2007, no município de Juazeiro/BA.

5. Qual é a sua formação artística e ou acadêmica?

Dançarina, atriz e coreógrafa com DRT 3370 (SATED/BA-2007), Pedagoga, Teóloga, especializando em Dança Educacional e Artes Cênicas. 


\section{Qual a linguagem artística desenvolvida pelo grupo?}

Teatro (palco, rua, clown) e danças de matriz africana.

\section{Faça um breve histórico do grupo, suas principais conquistas e dificuldades.}

Em abril de 2007, chegamos ao município de Juazeiro/BA, eu, Ioná Pereira, meu esposo Elson Campos e minha filha Maria Laura Campos,trazidos pela instituição NAENDA (Núcleo de Arte Educação Nego d'Água) para desenvolver um trabalho no município de Juazeiro/BA voltado para as questões negras a partir de projetos que já desenvolvíamos nos municípios de Salvador/BA e Camaçari/BA, iniciamos então na entidade ministrando oficinas de danças populares (com foco maior nas danças de Matriz Africana) e teatro, em julho do mesmo ano percebemos a necessidade de fundar um grupo de dança e teatro que levasse aos palcos da região do vale do São Francisco a temática negra, nasce aí: A Cia. de Danças e Teatro Nego D’água que vai ter nos seus primeiros anos um foco maior na dança, em 2009 estreia o espetáculo $O$ palhaço e a bailarina (com técnica de clown), em 2012 nos afastamos da entidade NAENDA e focamos os trabalhos no fortalecimento da dança negra no Território. Nestes 8 anos de trabalho destacamos como conquista: o Projeto Formando em Rede, que é um encontro anual com grupos de teatro e dança do território onde acontece debates e oficinas para o fortalecimento dos seguimentos e o Projeto Dançando no Território do Sertão do São Francisco onde passamos uma semana em cada município dando oficinas e promovendo bate papo sobre a Matriz Africana, Questões de Gênero e Negritude. Nosso trabalho hoje tem se voltado cada dia mais para assessoria técnica aos grupos e profissionais da região do Vale do São Francisco que querem trabalhar com esta temática. Já como dificuldades destacamos: a falta de espaços com infraestrutura básica para ensaios, editais específicos para as artes negras, cursos e oficinas especificas sobre a nossa temática.

\section{O que é teatro negro ou dança negra na concepção do grupo?}

Uma ferramenta que possibilita fortalecer a luta contra o preconceito, racismo, intolerância.

\section{Quais são os referenciais teóricos ou práticos?}

$\mathrm{Na}$ parte prática com dança busco usar muito da experiência que adquiri na minha participação em Salvador/BA em grupos como: Malê de Balê, Yaobá, Oficinas Ara Ketu entre outros. Elson trabalhando com o teatro também parte da experiência dele nos vários grupos ao qual pertenceu e espetáculos que dirigiu desde 1996. Já o material teórico é bem vasto pois temos uma mini biblioteca em casa a qual sempre buscamos atualizar com a aquisição de novos livros e a partir daí podemos ter como referencial teórico desde Artur Ramos em As Culturas Negras no Novo Mundo. São Paulo: nacional, 1979, até chegar hoje a Jorge Sabino e Raul Lody em seu Danças de matriz africana: antropologia do movimento. Rio de Janeiro: 
Pallas, 2011.

10. Qual é a metodologia de trabalho do grupo?

Oficinas, cursos, que a partir da pesquisa de um determinado tema trabalham com teoria e prática onde uma complementa a outra.

11. Quais são os achados estéticos, os achados da poética do grupo no que se refere à arte negra?

Os espetáculos:

Raízes brasileiras (2009) - Traz à cena a história do povo Brasileiro a partir das contribuições dos índios, Europeus e Africanos;

Axé dos orixás (2011) - Coletânea de músicas populares que falam ou fazem referências aos Orixás.

\section{O trabalho do grupo é político? Por quê?}

Sim! Pois em nossos trabalhos buscamos sempre conduzir o elenco e o público a uma reflexão sobre as questões do negro na sociedade, buscando assim possibilitar mudanças sociais.

13. Gostaria de acrescentar algo mais?

Não respondida.

\section{Questionário 4}

Eliete dos Santos Miranda. Cia Corpafro - A arte de dançar afro - RJ

\section{Qual é o seu nome, o nome do seu grupo, companhia ou outro agrupamento?}

Eliete dos Santos Miranda. Cia Corpafro- A arte de dançar afro - RJ.

\section{O grupo tem quantos integrantes? Nomes? Formação artística?}

Tem 6 - Macário Silva - guia turístico e ator dançarino;

Dejanete Dialise - estudando comunicação - atriz e dançarina;

Jonatas Vitelino - ator e circense - formação;

Duelem Castro formada em artes cênicas - cantora, dançarina atriz;

Flavia dos prazeres - Atriz e dançarina - formação cinema;

Luanda Negreiro - formação jornalismo - função produtora.

3. Qual é a sua atividade no grupo?

Coordenadora, atriz e dançarina.

4. Em que ano surgiu, em que cidade?

Surgiu em 2005.

5. Qual é a sua formação artística e ou acadêmica? 
Acadêmica terminando dança artística arte educadora social.

\section{Qual a linguagem artística desenvolvida pelo grupo?}

Linguagem da dança aliada ao teatro e poesia. Com discussão baseada no movimento corporal e a cultura popular brasileira, levando uma discussão sobre o cotidiano e o CORPO como reutilização destes gestos como Matriz de um alfabeto ritualístico que resgata o conhecimento da civilização africana.

\section{Faça um breve histórico do grupo, suas principais conquistas e dificuldades.}

A Cia Corpafro surgiu a partir do momento em que vim percebendo que alguns jovens e adultos que faziam aulas e oficinas não tinham um perspectiva de vida com a arte, daí surgiu o grupo com objetivo de desenvolver uma linguagem de movimento e ação corporal que leve a uma discussão contida nas mensagens corpórea e assim resgatar registros ancestrais guardados no corpo.com Objetivo de criar um canal de reconhecimento da identidade étnica racial que são plurais ,nos dando a possibilidade de- descobrir uma cultura cada vez mais próxima. As nossas principais conquistas com muita dificuldade de ter um respaldo e dignidade é através das nossas pesquisas. E apresentações de aulas demonstrativas com espetáculos para mantermos muito difícil viver da arte tem que ter respaldo. Dificuldades: Ganhar um edital, escrever o edital, conseguir teatros para apresentações, ter um espaço próprio e pagar um espaço para ensaios.

\section{O que é teatro negro ou dança negra na concepção do grupo?}

Para o grupo o teatro e dança negra estão contidos nos nossos corpos cotidianos e nas nossas falas, é o que nos deixa mais fortes quando vemos e revemos a expansão dos povos negros em sua diáspora e as atuais condições. É quando mantemos um dialogo sobre corpos coreográficos e cênicos transformados em territórios vivenciais.

\section{Quais os referenciais teóricos ou práticos?}

Referências praticas; Bando de Teatro Olodum, que eu fui uma das fundadoras, Zebrinha, Nadir Nobrega , Luiz Marfo, YaleAiyê, Olodum Male de Bale, Mestre King, Cleide Morgan. Referências teóricas: Pina Baús, Eugenio Barba, Sojigue Coité, livros do fórum de Performance negra, poesia e textos afro brasileiros e africanos.

\section{Qual é a metodologia de trabalho do grupo?}

Através de gestos simples do dia a dia e de uma grande Caminhada a que chamamos Caminhada da Diversidade (Eliete Miranda - 2014). Os componentes são convidados a trocar conhecimentos em torno do assunto em questão. Nos encontros, também será estimulada a sensibilização para a dança, seus aspectos lúdicos, psicológicos e fisiológicos, convidando professores de- dança, teatro e poesia. É prevista a elaboração de material, como apostilas a 
ser utilizado durante a oficina, além de vídeos para estimular e enriquecer os debates. Ao final da oficina, as turmas realizarão uma apresentação em evento público.

11. Quais são os achados estéticos, os achados da poética do grupo no que se refere à arte negra?

O achado é reescrever conceitos de uma estética que foi negada a todo instante e que sempre esteve nos nossos corpos, trazendo como fio condutor a presença da mulher como símbolo de poder e arquétipo dos valores mágicos da fertilidade (a mulher e o simbólico).

\section{O trabalho do grupo é político? Por quê?}

Sim, é político a partir do momento em que nos reunimos para discutir os nossos direitos e deveres diante de uma sociedade racista e machista já temos um corpo político.

\section{Gostaria de acrescentar algo mais?}

Sim, que gostei muito da sua proposta de estar contribuindo para a divulgação de uma nova estética negra através de leitura e comprometimento coletivo, refletindo a importância das artes vivas como instrumento de socialização para formação de cidadãs (aos) críticos e participativos. Obrigada pela atenção e eu sou muito sua fã. Eliete dos Santos Miranda.

\section{Questionário 5}

Carmem Luz - Cia. ÉTNICA de Dança e Teatro - RJ

\section{Qual é o nome do seu grupo ou companhia?}

Cia. ÉTNICA de Dança e Teatro - RJ.

\section{O grupo tem quantos integrantes? Nomes? Formação artística?}

Não respondida.

\section{Qual é a sua atividade no grupo?}

Fundadora, diretora artística e coreógrafa.

\section{Em que ano surgiu, em que cidade, há quanto tempo existe?}

Outubro de 1994, na Cidade do Rio de Janeiro. Há 21 anos.

\section{Qual é a linguagem artística desenvolvida pelo grupo?}

Uma linguagem multidisciplinar e transversal. Dança e Teatro em permanente diálogo com as artes visuais, a literatura, o cinema e a história da diáspora negra.

\section{Qual é a sua formação artística e ou acadêmica?}

Não respondida.

\section{Faca um breve histórico do grupo, suas principais conquistas e dificuldades.}

Há 21 anos a Cia. Étnica se dedica à pesquisa, à criação de obras artísticas, à produção e à capacitação de jovens artistas. Seu trabalho reflete sobre a experiência afrodescendente no 
mundo contemporâneo em suas diversas temporalidades e espacialidades. Suas criações expõem o apreço pela pesquisa histórica e antropológica, ponto-de-partida de uma escrita singular, marcada por um pensamento estético onde transitam diferentes saberes e campos artísticos. Ao longo de sua trajetória a Companhia Étnica realizou peças de dança e teatro, performances, instalações coreográficas, documentários, projetos educacionais e socioculturais. Suas obras foram vistas por amplo público em teatros, museus, parques, festivais e mostras de cinema, favelas, praças e equipamentos culturais de diversas regiões brasileiras. Em 1997, a Cia Étnica mudou-se para o Morro do Andaraí, zona norte da cidade do Rio de Janeiro, onde manteve sua base até 2010. Apoiada por sua premiação em concursos públicos para projetos de capacitação profissional de jovens, recursos próprios e resistência pessoal, a Cia Étnica pode concretizar e irradiar, do centro daquela favela carioca, suas principais premissas: dedicou-se à pesquisa e à criação de linguagem em dança contemporânea, incentivou a formação de novos públicos, orientou e coordenou a formação de novos profissionais para as Artes Cênicas, promoveu trocas e partilhas com a comunidade local, a sociedade brasileira e internacional, através da elaboração e gestão de projetos onde a conscientização sociocultural, a experimentação artística e o desenvolvimento pessoal, social, profissional e artístico de jovens, crianças e adultos de áreas populares, encontravam-se alinhados. Sua metodologia, suas práticas e percurso tornaram-se modelo e inspiração para uma quantidade significativa de jovens negros e mestiços desenvolverem, atualmente, seus próprios trabalhos, quer como coreógrafos(as), promoters, atores, atrizes, produtores(as), bailarinos(as) e intérpretes-criadores; quer como técnicos e diretores(as) de suas próprias companhias de dança. Além de obras cênicas a Companhia Étnica produziu e exibiu no Brasil e no exterior quatro documentários. Seu mais recente projeto audiovisual, Um Filme de Dança, sobre a vida e a obra de criadoras e criadores negros de dança, é um documentário pioneiro na História da Dança Brasileira. A Cia. Étnica foi criada na cidade do Rio de Janeiro em 1994 pelas artistas Carmen Luz e Zenaide Djadillê (1994 a 1998). É composta por bailarinos, atores e músicos: Amanda Corrêa, Alessandro Portugal, Ana Lucia Gregório, Carmen Luz, Claudia Martins, Elton Sacramento, Flavinny Oliveira, Gessica Justino, Rodrigo Brayner, Silvia Patrícia, Ubiratã Paixão Junior. Desde a fundação, Carmen Luz desenvolve sua metodologia, concebe, escreve e dirige suas criações. Temos dificuldades sim. Todas aquelas que passam os afrodescendentes sob o império do pensamento branco que pauta as artes cênicas, o grande espelho de nossa sociedade. Muito já se disse que o trabalho da Cia. Étnica é referência. Mas mesmo agradecidos aos deuses e a nós mesmos por nossas conquistas, mesmo felizes com o reconhecimento que nos deram prêmios... O que fica 
mesmo, para além de todas as contribuições que possamos ter feito ou que fizemos e que temos condições de fazer...na prática...no cotidiano...continuamos sempre começando e recomeçando... tudo de novo...sem dinheiro nenhum ou pouquíssimo dinheiro para criar, sem espaço...sem equipe...sem subvenção...

\section{O que é teatro negro ou dança negra na concepção do grupo?}

Artes da cena e do corpo cujo protagonismo multidimensional do corpo negro reflete a experiência negra e seus diversos e diferentes contextos no mundo.

\section{Quais são os referenciais teóricos ou práticos?}

Cada trabalho requer uma teoria ou um conjunto de teorias articulado a um conjunto de práticas. De uma maneira geral, a cultura popular inventada e reinventada no continente americano; artistas, pensadoras e pensadores afrodescendentes e europeus. Do Teatro Experimental do Negro, mais propriamente do Abdias, herdamos uma espécie de desejo experimental afro-brasileiro. As teóricas feministas negras de diferentes gerações são referências constantes.

\section{Qual é a metodologia de trabalho do grupo?}

Para cada trabalho um conjunto específico de técnicas são acionadas e utilizadas. Comum a todos os trabalhos há: a perspectiva histórica e conjuntural do corpo negro - em especial, dos corpos das mulheres negras -; a observação cotidiana de gestos e movimentos produzidos nos espaços urbanos e populares da cidade do Rio de Janeiro; o treinamento para desenvolver nossa autoestima, aperfeiçoar nossa autodeterminação.

11. Quais são os achados estéticos, os achados da poética do grupo no que se refere à arte negra?

A expressividade, a bricolagem, a preocupação formal, a espiritualidade e imagens de resistência, dor e esperança.

\section{O trabalho do grupo é político? Por quê?}

Sim, porque a Cia. Étnica foi criada como um espaço artístico, de formação e irradiação de novas e outras possibilidades, de Resistência. Permanece produzindo há 22 anos - ora com patrocínios advindos de editais públicos e prêmios, ora com recursos próprios de sua fundadora, companheirismo da equipe -. Para além de sua pesquisa, criação e produção artística, atua objetivamente na formação de artistas, técnicos e no empoderamento de jovens moradoras e moradores de favelas na cidade do Rio de Janeiro.

\section{Gostaria de acrescentar algo mais?}

Não respondida. 


\section{Questionário 6}

Coletivo Black Horizonte - BH

\section{Qual é o nome do seu grupo ou companhia?}

Coletivo Black Horizonte $-\mathrm{BH}$.

\section{O grupo tem quantos integrantes? Nomes? Formação artística?}

Mascote Dewson, (dançarino(Gabi Guerra, (Artes Visuais) Tatu Guerra (VJ).

\section{Qual é a sua atividade no grupo?}

Gil Amâncio. Músico e compositor de trilha sonora.

\section{Em que ano surgiu, em que cidade, há quanto tempo existe?}

2010 - Belo Horizonte, cinco anos.

\section{Qual é a linguagem artística desenvolvida pelo grupo?}

Arte Negra Contemporânea e tecnologia

\section{Qual é a sua formação artística?}

Não respondida.

\section{Faca um breve histórico do grupo, suas principais conquistas e dificuldades.}

Desde 2007 quando criei o NEGA - Núcleo Experimental de Arte Negra e Tecnologia cujo objetivo é ser um espaço de estudo, pesquisa, criação e formação que tinha o desejo de transformas esses estudos em um espetáculo. Em 2010 Mascote Dewson (Dançarino de danças urbanas) me convidou para montar uma coreografia para a mostra 1,2 na Dança, como dizem em Minas juntou a fome com a vontade de comer. Convidei minha filha Gabi Guerra (artes visuais) e meu filho Tatu Guerra (VJ) e assim começou o Coletivo Black Horizonte. Nossas conquistas foram os convites que tivemos para participar de festivais e mostra de que nos propiciaram construir uma linguagem cênica contemporânea cujos fundamentos vinham dos procedimentos artísticos presentes nos terreiros de candomblé, nos reinados e na capoeira das rodas de samba, do afro futurismo e da cultura hip hop. Nossa grande dificuldade é ter recursos para manutenção do espaço e do Coletivo.

\section{O que é teatro negro ou dança negra na concepção do grupo?}

É um fazer artístico que tem como eixo a pesquisa da experiência do corpo negro nas diásporas africanas, os territórios onde esse corpo pode exercitar a sua liberdade de criação e expressão e assim restituir sua humanidade, e os modelos societários que emergiram desses territórios.

\section{Quais são os referenciais teóricos ou práticos?}

Os referenciais são os estudos e pesquisas das relações entre pensamento, invenção e criação dos africanos e seus descendentes no que Paul Gilroy chama de Atlântico Negro. As relações 
entre corpo e espaço, voz e movimento, som e corpo, a visualidade, a maneira como a população negra vai se reinventando a partir dos quilombos urbanos e rurais. E autores e autoras dos movimentos Afrofuturismo, mangue beat, hip hop, dos black inventors, Henrique Cunha, Jesse de Souza, leda Martins a poesia de Ricardo Aleixo e por ai vai.

\section{Qual é a metodologia de trabalho do grupo?}

Estudo, estudo, estudo, improvisação, improvisação, improvisação.

11. Quais são os achados estéticos, os achados da poética do grupo no que se refere à arte negra?

Que desde que pisamos nas Américas construímos uma arte contemporânea onde som, palavra, movimento, imagem se integram, dialogam, se transformam sem que saibamos onde começa uma e termina a outra. Que o brincar e a improvisação são elementos fundantes da nossa maneira de criar e que o pensamento digital, fractal esta presente na África em nossos jogos de adivinhação, em nossa arquitetura, nas tranças dos cabelos. Ou seja, o pensamento mais sofisticado nos campo da ciência, da tecnologia, da arte, estão integrados nas artes de cuidar de si e do outro em nossos fazeres artísticos e culturais.

\section{O trabalho do grupo é político? Por quê?}

Sim, porque estamos ocupando com nossos corpos negros todos os espaços artísticos e de formação que podemos.

\section{Gostaria de acrescentar algo mais?}

Não respondida.

\section{Questionário 7}

Rosana Machado de Souza - São João Del Rei/MG - TeatrIFdel Rei

\section{Qual é o seu nome, o nome do seu grupo, companhia ou outro agrupamento?}

Rosana Machado de Souza. São João Del Rei - MG. Nome do grupo: TeatrIFdel Rei.

\section{O grupo tem quantos integrantes? Nomes? Formação artística?}

O projeto 2015 teve 5 bolsistas remunerados, 1 aluno voluntário, 1estagiario do curso de Teatro (da UFSJ), 1 participante da comunidade externa além do coorientador que ajudou na produção. Portanto 10 pessoas contando comigo.

\section{Qual é a sua atividade no grupo?}

O grupo é um projeto de extensão do IF Sudeste MG- campus São João del-Rei do qual sou coordenadora. No grupo de teatro sou diretora e, eventualmente assumo funções como: produtora, roteirista, atriz. Depende do trabalho a ser desenvolvido e do envolvimento dos outros componentes do grupo. 


\section{Em que ano surgiu, em que cidade, há quanto tempo existe?}

O grupo existe desde 2012 na cidade de São João del-Rei/MG. 4 anos.

\section{Qual é a sua formação artística e ou acadêmica?}

Sou Bacharela e Licenciada em Artes Cênicas pela UFMG. Estou terminando o Mestrado em Artes pela mesma universidade.

\section{Qual é a linguagem artística desenvolvida pelo grupo?} Teatro.

\section{Faca um breve histórico do grupo, suas principais conquistas e dificuldades.}

O TeatrIFdel-Rei surgiu como um projeto de extensão no IF Sudeste MG - Campus São João del-Rei e, nesse tempo de existência desenvolveu projetos artístico-educacionais diversos. A principal conquista desse projeto de extensão foi que, no ano de 2015, conseguimos ter 5 bolsistas remunerados contribuindo para a permanência e desenvolvimento de 5 alunos da instituição. A principal dificuldade na área artística é a descontinuidade dos membros do grupo. Por ser um projeto de extensão, os alunos-atores passam pelo projeto e pouco se mantém após a conclusão do curso ou encerramento da bolsa.

\section{O que é teatro negro ou dança negra na concepção do grupo?}

Acredito que ter atores negros em cena de forma que esses atores tenham papéis que possam ser desenvolvidos de forma a ter uma construção de personagem complexa. Sem estereótipos, sem superficialidade.

\section{Quais são os referenciais teóricos ou práticos?}

Tenho como referencial teórico no que se refere ao Teatro Negro as autoras Leda Maria Martins, Evani Lima e Cristine Douxami. Referencial prático utilizo as experiências de alguns grupos que fazem parte do Fórum Nacional de Performance Negra.

\section{Qual é a metodologia de trabalho do grupo?}

A metodologia varia bastante de acordo com o projeto de extensão aprovado a cada ano.

11. Quais são os achados estéticos, os achados da poética do grupo no que se refere à arte negra?

Ainda não tenho um pensamento construído sobre esses achados. Mas em 2015 o projeto desenvolvido me deu algumas pistas e também questionamentos sobre o lugar do negro mestiço no Teatro Negro. Ainda estou em busca de construir um pensamento mais elaborado sobre isso.

\section{O trabalho do grupo é político? Por quê?}

Sim. Na minha concepção e na minha forma de trabalhar, todo trabalho artístico é político. Acredito que toda vez que optamos por uma estética, escolhemos algo para fazer parte ou 
ficar fora dos nossos trabalhos artísticos, estamos fazendo escolhas também políticas. Por exemplo: colocar atores negros em cena isso é uma escolha política, mas deixar de colocar, na minha concepção, também o é.

\section{Gostaria de acrescentar algo mais?}

Não respondida.

\section{Questionário 8}

\section{Adriana Paixão grupo Capulanas Cia de Arte Negra - SP}

\section{Qual é o seu nome, o nome do seu grupo, companhia ou outro agrupamento?}

Adriana Paixão grupo Capulanas Cia de Arte Negra - SP.

\section{O grupo tem quantos integrantes? Nomes? Formação artística?}

O núcleo artístico tem 4 integrantes todas com formação artística.

\section{Qual é a sua atividade no grupo?}

Intérprete pesquisadora e produtora cultural.

\section{Em que ano surgiu, em que cidade?}

Capulanas surgiu em 2007.

\section{Qual é a sua formação artística e ou acadêmica?}

Sou formada em comunicação das Artes do Corpo habilitação em teatro PUC-SP e Ciências Sociais pela Unifesp.

\section{Qual é a linguagem artística desenvolvida pelo grupo?}

Teatro Negro tal como as linguagens de dança, canto e performance negra contemporânea.

\section{Faça um breve histórico do grupo, suas principais conquistas e dificuldades.}

Nosso primeiro espetáculo - Solano Trindade e suas negras poesias - contou com um processo de criação coletiva fundamentado em uma concepção cênica que tornasse híbrido teatro, dança e música dando vida às poesias, mas também, explorando as próprias vivências cotidianas de cada componente. Em 2008 com o Programa VAI da Secretaria de Cultura da cidade de São Paulo. No ano de 2009, com o PROAC - Edital Inédito de Teatro da Secretaria de Estado da Cultura com apresentações na Fundação Casa, Teatro Solano Trindade. No mesmo ano através do Edital de Intercâmbio Cultural do MINC, o espetáculo ficou em cartaz em Salvador - BA no Teatro Gamboa Nova. 2010 e 2012 fomos contempladas pela Lei de fomento ao teatro da cidade de São Paulo com os projetos Pé no Quintal - circulação do espetáculo Solano Trindade e suas negras poesias e Sangoma, pesquisando a saúde da mulher negra, que resultou em 2013 no $2^{\circ}$ espetáculo da Cia. Através do Edital de passagens do MinC, fomos para Moçambique, onde durante o mês de fevereiro de 2012 fizemos o 
lançamento do livro Em[goma] e realizamos uma série de trocas artísticas sobre a experiência do Projeto Pé no Quintal e sobre as temáticas que guiavam a pesquisa de nosso novo espetáculo: Sangoma. Ainda em 2012, fomos contempladas pela $2^{\mathrm{a}}$ vez na Lei de Fomento ao Teatro da Cidade de São Paulo, com o Projeto de pesquisa "Sangoma" e inauguramos a sede da Cia na periferia da zona sul - a Goma Capulanas - um espaço voltado para a formação e difusão da arte, educação e cultura negra. No final de 2013 com o término da temporada de estreia, nos deparamos com o vazio que o final de um processo tão intenso quanto foi a pesquisa e montagem deste espetáculo poderia trazer a cada uma de nós. A retomada de ensaios e treinos nos impulsionou e pensar mudanças na peça, pensando em como deixar a cura ainda mais presente. Criamos novas ligações de cena, mudança do figurino e um acento no canto que é elemento transversal de muitos rituais sagrados de cura. Em 2014 fomos contempladas com a $24^{\circ}$ edição da lei de fomento ao teatro, com o projeto: Sã - Da cura ao Gozo, que realizou cerca de 40 apresentações do espetáculo Sangoma. Ao longo de nossa trajetória, vivenciamos por momentos desafios, como quando tentamos alugar uma casa para a construção da sede do grupo, e ao chegarmos na imobiliária o mesmo imóvel que estava disponível por telefone não podia ser alugado para 4 mulheres pretas, ou ainda dá vez que em uma apresentação de um festival de teatro nosso tema foi ridicularizado pelo fato de que existem mulheres brancas na periferia, ou ainda falas de que não éramos teatro e sim dança, ou que o teatro não tem cor. Felizmente nossos aprendizados foram maiores e relevantes aos nossos processos e existimos/resistimos como um grupo de arte de mulheres pretas e periféricas.

\section{O que é teatro negro ou dança negra na concepção do grupo?}

O teatro negro é uma forma expressiva anti-hegemônica, se entendermos a cultura ocidental como dominante no Brasil, um teatro é negro quando seus criadores invocam para si uma origem negro-africana, quando coloca a perspectiva diaspórica africana como ponto de partida e chegada. Um teatro é negro quando tem consciência, que nem o negro nem o africano existem por si e para si mesmos" (SALOMÃO, 2012, p. 104).

\section{Quais são os referenciais teóricos ou práticos?}

São muitos nossos referencias teórico e práticos tais como Salloma Salomão, Julio Moracen Narranjo, Lucrecia Paco, Bando de Teatro Olodum, bel hoocs, Beatriz Nascimento, Lelia Gonzales, Alejandro Frigeiro, Stuart Hall, Ivani Tavares, entre outros.

\section{Qual é a metodologia de trabalho do grupo?}

Nossa poética parte da fisicalidade, e a oralidade tem sido um elemento centralizador de todo o processo criativo, que começamos pelas conversas, onde revelamos os anseios, dúvidas e 
vontades e a partir disso é definido o tema que será o gerador da pesquisa. Levamos todo conteúdo discutido para as improvisações corporais. Outros aspectos das discussões podem aparecer não como texto, mas como gestualidade. Por fim, são elaboradas as representações corporais e produzidos textos escritos, que voltam a ser transformados em orais com as construções de cenas.

11. Quais são os achados estéticos, os achados da poética do grupo no que se refere à arte negra?

Acreditamos que nossa arte parte do tripé arte política e religiosidade na construção estética negra.

\section{O trabalho do grupo é político? Por quê?}

Sim, quando defendemos o teatro negro e o protagonismo das mulheres negras estamos atuando politicamente.

\section{Gostaria de acrescentar algo mais?}

Não respondida.

\section{Questionário 9}

Evandro Nunes - Negraria - Coletivo de Artistas Negros/as de BH

1. Qual é o seu nome, o nome do seu grupo, companhia ou outro agrupamento?

Evandro Nunes - Negraria - Coletivo de Artistas Negros/as de BH.

\section{O grupo tem quantos integrantes? Nomes? Formação artística?}

Não respondida.

\section{Qual é a sua atividade no grupo?}

Presidente e ator/pesquisador.

\section{Em que ano surgiu, em que cidade?}

Em 25 de outubro de 2008. 8 anos.

\section{Qual é a sua formação artística e ou acadêmica?}

Tenho uma formação livre em arte, sou pedagogo e arte-educador.

\section{Qual é a linguagem artística desenvolvida pelo grupo?}

O grupo oferece subsídios teóricos e práticos para outros artistas negr@s, assim contribui com a criação, manutenção e difusão de produções de Artistas Negr@s.

\section{Faça um breve histórico do grupo, suas principais conquistas e dificuldades.}

A NEGRARIA - Coletivo de Artista Negro/a de Belo Horizonte, é uma associação cultural sem fins lucrativos, e tem como princípios valorizar o trabalho do artista negro, nas áreas de artes cênicas, musica, dança, arte educação, áudio visual, plásticas e literatura de Belo 
Horizonte, priorizando o protagonismo: na produção e na atuação; na estética e na plástica; na corporeidade e na performance; na sonoridade melódica e na rítmica; na dinâmica da tradição e da contemporaneidade, respeitando as especificidades das linguagens artísticas, contemporâneas e matriciais, focando a temática da negrura, enquanto fator aglutinador e formador identitário, desvinculada de estereótipos, preconceitos e discriminação. Contribuindo para a criação, manutenção e difusão de produções de Artistas Negros. e/ou que abranjam a temática Negra contemporânea e tradicional. O Coletivo há dois anos desenvolve o projeto "Diálogos com as Africanidades" que prioriza duas das ações fundantes da NEGRARIA, que são: a formação e o fazer artístico. Portanto o "Diálogos com as Africanidades" é uma pequena mostra de pensamentos e de linguagens artísticas que têm como foco principal o negro enquanto proponente, objetivando que a cidade de Belo Horizonte tenha a oportunidade de acompanhar minimamente as produções culturais em curso, que dialogam com a diáspora.

\section{O que é teatro negro ou dança negra na concepção do grupo?}

É um teatro e/ou dança que tem o negr@ como protagonista da sua história, onde as subjetividades da negritude estejam impressas, seja no figurino, na musicalidade ou sonoridade, na corporeidade, na dramaturgia, e obviamente seja feito por negros.

\section{Quais são os referenciais teóricos ou práticos?}

Teóricos:

MARTINS, Leda Maria. A Cena em Sombras. Série Debates. Teatro. Editora Perspectiva. São Paulo, 1995.

EVARISTO, Conceição. Breves reflexões sobre literatura afro-brasileira. In: OLONADE - o Teatro da Comuns, I. 2007. Rio de Janeiro. Palestras. Rio de Janeiro: Cia dos Comuns, 2007, p. 36-44.

MULLER, Ricardo Gaspar. Identidade e cidadania: o Teatro Experimental do Negro, In: Revista Dionysios, n²9, 1988.

ROSSI, Luiz Gustavo Freitas. Epidderme em cena, raça, nação e teatro negro no Brasil. Cadernos Pagu n²8. Campinas, 2007

Rosalia Diogo. Cidadania, reconhecimento e formação identitária. In: Midia e Racismo: ensaios. Belo Horizonte: Mazza Edições, 2004, p.29-40.

GOMES, Nilma Lino e MUNANGA, Kabengele. O negro no Brasil Hoje. São Paulo: Global, 2006.

THORTON, John. Os africanos nas sociedades coloniais do Atlantico. In: A África e os africnos na formação do mundo atlântico, 1400-1800. Tradução de Marisa Rocha Mota. 2. Ed. 
Rio de Janiero: Elsevier, 2004. Cap 05, p.189-215.

Registros do I, II E III Fórum Nacional de Performance Negra, registrado no livro de mesmo nome por Bairros, Luiza e Mello, Gustabvo (Orgs.). Rio de Janeiro: Conceito, 2005.

Grupo de Estudos Multidisciplinares da Ação Afirmativa - GEMAA. (2011) "Ações afirmativas".

Práticos:

Todo trabalho desenvolvido pelo TEATRO NEGRO E ATITUDE, Cia Seraqué, Cia Baoba de Arte Negra, e demais artistas negr@s da cidade de BH.

\section{Qual é a metodologia de trabalho do grupo?}

Em, cada grupo/coletivo/agrupamento e/ou trabalho muda a metodologia. No caso especifico da UP3 - União Performática Pessoas da Pessoa, o trabalho tem sido construído da seguinte forma: os atores/pesquisadores, diretor e dramaturgo imergem no trabalho e passam a fazer uma residência artística de alguns dias para que o tema e as primeiras inspirações apareçam. Depois o Dramaturgo traz seus primeiros rascunhos da cena, e os atores/pesquisadores constroem a cena. Para isso eles utilizam imagens, objetos e sonoridade, todas têm que ter haver com nossa negritude. Na sequência o diretor coloca o seu olhar na cena construída. $\mathrm{O}$ resultado dessa forma de trabalho foram os espetáculos Mãe Joana de Ekedi e In Sã - O universo do Rosário em Nós, esse ainda em circulação.

11. Quais são os achados estéticos, os achados da poética do grupo no que se refere à arte negra?

Ainda estamos refletindo sobre esse achado estético e poético, estamos num processo de elaboração de um texto que fale sobre isso.

\section{O trabalho do grupo é político? Por quê?}

Sim, pois o estar em cena tem conotações variantes, mas que nos levam a um mesmo sentido: ser o foco da atenção, ser protagonistas de nossa história. Como disse Leda Maria Martins “a cor do individuo nunca é simplesmente uma cor, mas um enunciado repleto de conotações e interpretações articuladas socialmente, com um valor de verdade que estabelece marcas de poder, definindo lugares, funções e falas (MARTINS, 1995, p. 39)”. Sendo assim estar em cena, para nós, é um ato político.

\section{Gostaria de acrescentar algo mais?}


Não respondida.

\section{Questionário 10}

Núcleo Afro-brasileiro de Teatro de Alagoinhas - Bahia - NATA

\section{Qual é o seu nome, o nome do seu grupo, companhia ou outro agrupamento?}

Fernanda Júlia. Núcleo Afro-brasileiro de Teatro de Alagoinhas - Bahia - NATA.

\section{O grupo tem quantos integrantes? Nomes? Formação artística?}

Não respondida.

\section{Qual é a sua atividade no grupo?}

Diretora artística.

\section{Em que ano surgiu, em que cidade?}

O NATA foi fundado em 17 de outubro de 1998, na cidade de Alagoinhas, Bahia.

\section{Qual é a sua formação artística e ou acadêmica?}

Ensino superior completo, graduação em Direção Teatral pela Escola de Teatro da UFBA. Mestranda do Programa de Pós-graduação em Artes Cênicas PPGAC - UFBA, com a dissertação: Ancestralidade em cena - Candomblé e Teatro na formação de uma encenadora.

\section{Qual é a linguagem artística desenvolvida pelo grupo?}

Teatro.

\section{Faça um breve histórico do grupo, suas principais conquistas e dificuldades.}

O Núcleo Afro brasileiro de Teatro de Alagoinhas - NATA, fundado em 17 de outubro de 1998, na cidade de Alagoinhas surgiu de um festival estudantil de Teatro representando o Colégio Estadual Polivalente de Alagoinhas. Nestes 17 anos de trabalho o NATA vem realizando montagens teatrais, oficinas, leituras dramáticas, e movimentando o espaço teatral com projetos que discutem, divulgam e valorizam a cultura Afro-Brasileira. Nossos espetáculos possuem como eixo norteador a história, cultura e religiosidade Afro-Brasileira, a fim de desmitificar os preconceitos e as imagens equivocadas que povoam histórica e culturalmente o imaginário coletivo da sociedade, resultado de um processo de colonização e racismo. As dificuldades encontradas neste percurso são as que fazem coro nas vozes dos grupos de teatro negro no Brasil, dificuldade de patrocínio e apoios, principalmente devido a temática abraçada pelo grupo, o que nos deixa sempre vivendo um ano de cada vez, pois assim não conseguimos planejar antecipadamente ações e programações para o grupo, além de não conseguir manter o elenco voltado para as questões do grupo integralmente, pois todos precisam fazer outras atividades.. Dificuldade de obtenção de recursos para locação de sede, sendo a busca por um local de ensaio sempre um drama a mais para as montagens. Mesmo com estas dificuldades o 
NATA vem conseguindo se consolidar no cenário nacional. Eis algumas de nossas vitórias. No ano de 2009, no intuito de contribuir efetivamente o NATA montou o espetáculo Siré Obá "A festa do rei", uma grande homenagem aos Orixás e a todo o povo de santo do Brasil, construída dramaturgicamente através dos Orikis (poesias em exaltação aos Orixás), sua encenação inspirou-se nos rituais públicos das Comunidades de Axé (Ilê Axé) da Bahia. O Siré Obá foi montado no ano de 2009 e apresentado na cidade de Alagoinhas, no Centro de Cultura de Alagoinhas e em quatro Comunidades de Axé (Ilê Axé) do município sendo o primeiro projeto de um grupo dessa cidade que ganhou um edital público de montagem. Neste mesmo ano realizou temporadas no Teatro Vila Velha em Salvador, apresentou-se no III Fórum Nacional de Performance Negra, encerrou o I Festival de Teatro do Subúrbio de Salvador no Centro Cultural Plataforma. O espetáculo recebeu três indicações ao Prêmio Braskem de Teatro 2009: Melhor espetáculo adulto, direção revelação para Fernanda Júlia (diretora e autora) e além da indicação o prêmio Braskem na categoria especial para Jarbas Bittencourt, pela direção musical da montagem. Ainda como parte do projeto Siré Obá, o NATA realizou em o I IPADÊ - Fórum Nata de Africanidade, que reuniu Yalorixás, Babalorixás, a Comunidade de Axé, a Comunidade artística e a Comunidade em geral para discutirem questões relacionadas ao Candomblé, e o processo criativo do espetáculo Siré Obá. Além da montagem Siré Obá, o NATA montou os espetáculos Axé Origem, encanto e beleza (2000), Senzalas A história, o espetáculo (2002) e Axé! (2003), montagens que colaboraram no combate a intolerância religiosa sofrida pelas Comunidades de Axé (Ilê Axé), instaurando a discussão e provocando reflexões. Em 2010, o NATA estreia o espetáculo Ogum Deus e Homem, montagem premiada pelo I Prêmio Nacional de Expressões Afro brasileiras patrocinado pela Fundação Cultural Palmares, Ministério da Cultura e CADON. Este espetáculo participou da segunda edição do Festival a Cena tá preta do Bando de Teatro Olodum em novembro do mesmo ano e realizou o II IPADÊ- Fórum Nata de Africanidade. No ano de 2011, o NATA foi convidado para integrar o quadro de grupos residentes do Teatro Vila Velha em Salvador, sendo o primeiro grupo do interior a realizar residência artística no respectivo teatro. Em 2012, o NATA foi aprovado no Edital Setorial de Teatro da Fundação Cultural da Bahia com o projeto de manutenção, criação, circulação e interatividade cênica ALAMOJU que prevê a realização de oficinas técnicas, workshops, seminário e a estreia da nova montagem do grupo o espetáculo infanto-juvenil EREMIM e foi selecionado também com o espetáculo Siré Obá para integrar a grade de programação da V Edição do Festival Internacional de Artes Cênicas da Bahia - FIAC - BA realizando apresentações do citado espetáculo na Arena do Teatro Sesc-Senac Pelourinho e na Centro Cultural de Alagados. 
Ainda neste ano o NATA é aprovado no Edital Demanda Espontânea da FUNCEB e realiza o projeto NATA Oná Ilú Ayê - O NATA pelos caminhos do mundo que consistiu na apresentação do espetáculo Siré Obá em quatro comunidades de axé de Salvador (Terreiro Mokambo, Abassá de Ogum, Ilê Axé Oxumarê e Gantois) e mais oito comunidades de axé em cidades do interior do estado (Catu, Alagoinhas, Feira de Santana, Dias D’avila, Cachoeira, Santo Amaro, Simões Filho e Inhambupe). No ano de 2013, o NATA com o espetáculo Siré Obá “A festa do rei” fez parte da programação do projeto Nova Dramaturgia de Melanina Acentuada sob a direção e produção de Aldri Anunciação que desenvolveu o projeto de ocupação do Teatro de Arena Eugênio Kusnet em São Paulo. Neste mesmo ano integramos a programação da I Mostra Baiana no Fringe do Festival internacional de Curitiba com apresentações também do Siré Obá e participamos da sexta edição do Festival Latino Americano - FILTE realizado pelo Oco Teatro, onde apresentamos o espetáculo Siré Obá na tenda do Teatro Popular de Ilhéus. Em 2014, estreamos o espetáculo Exu - A boca do universo, esta montagem integrou a programação do projeto Exu Sile Oná TCA que foi o projeto vencedor da $19^{a}$ edição do TCA. Núcleo, edital que consistiu em seis meses de ocupação artística do NATA no complexo do Teatro Castro Alves com a realização de 28 atividades que se dividiram em atividades de formação, de intercâmbio com a Cia do Miolo de São Paulo, artística e de difusão. Em sua primeira temporada no mês de março deste ano o espetáculo Exu - A boca do universo foi apresentado no Vão Livre do Teatro Castro Alves e circulou em mais três espaços culturais da cidade o Cine Teatro Solar Boa vista, a arena do Sesc - Senac Pelourinho e o Centro Cultural Plataforma o que totalizou mais de 2.500 espectadores. No mês de maio deste ano o NATA participou do I Abriu de leituras, projeto de leituras dramáticas idealizado e realizado pelo CAN - Cia Abdias do Nascimento que comemorou os dez anos de existência do grupo, nesta oportunidade o NATA realizou a leitura dramática do texto Anjo Negro de Nelson Rodrigues. No mês de setembro o NATA faz a abertura do Festival de Teatro Brasileiro - FTB no Centro Cultural Banco do Brasil em São Paulo com a apresentação do espetáculo Exu - A boca do universo. Exu continua em cartaz e o NATA participa nos meses de setembro e outubro dos festivais FILTE - BA e FIAC - BA. Em novembro realizamos nova temporada do espetáculo Exu - A boca do universo no Centro Cultural da Barroquinha. O espetáculo é indicado ao prêmio Braskem de Teatro em quatro categorias: Melhor espetáculo adulto, melhor espetáculo do interior, melhor direção, categoria especial para Thiago Romero pelo cenário, figurino e maquiagem do espetáculo. Em 2015, no mês de janeiro o NATA apresentou-se no Polo Teatral em Camaçari, festival patrocinado pela Braskem para indicar os melhores do interior da Bahia. Em fevereiro realizamos a abertura do 
Flitlã - Festival Itinerante de Teatro Latino Americano Âmbar com o espetáculo Exu - A boca do universo no Teatro Sesc-Senac Pelourinho e finalizamos nossa participação no Sarau du Brown, evento iniciado em novembro de 2014, onde abríamos o show de Carlinhos Brown com cenas do espetáculo Siré Obá - A festa do Rei e Exu - A boca do universo, além de fazermos pequenas aparições durante todo o show. Em março iniciamos o projeto Palco Giratório, onde realizamos 33 apresentações do espetáculo Exu - A boca do universo em 27 cidades pelo Brasil. Em dezembro o NATA vence o edital FUNARTE Míriam Muniz 2015 com o projeto NATAS em Solo - Seis Olhares sobre o mundo. Onde serão montados solos dos atores do NATA, frutos das pesquisas individuais desenvolvidas dentro do grupo, com execução prevista para o segundo semestre de 2016.

\section{O que é teatro negro ou dança negra na concepção do grupo?}

Esta definição encontra-se em construção para o grupo, por hora consideramos teatro negro, o teatro que além da presença de uma maioria de artistas negros na cena, abordam temas referentes a história e a cultura negra brasileira e o seus modos de representação cultural, político, éticos e estético.

\section{Quais são os referenciais teóricos ou práticos?}

O Candomblé é o nosso maior referencial, tanto prático, quanto teórico. Tanto do ponto de vista da antropologia, quanto da liturgia assim, figuras como Marco Aurélio Luz, Renato da Silveira, Juana Elbein Santos, Inaicyra Falcão, Leda Maria Martins, Luiz Nicolau Pares, Ana Maria Gonçalves e a teoria de Antonin Artaud, Grotowisk e Eugenio Barba e Bertolt Brecht. O teatro de Luiz Marfuz e Marcos Barbosa. Mãe Rosa de Oyá, babá Márgio d’Ogun, Tatá Anselmo e o babá Rychelmy Imbiriba são referenciais teórico-práticos. Além dos grupos inspiradores: Bando de Teatro Olodum, Cia Abdias Nascimento - CAN e Cia dos Comuns e o Fórum Nacional de Performance Negra. E os referenciais conhecidos durante o caminho CUTI, Cistiane Sobral, Gustavo Mello, Zebrinha, Jarbas Bittencourt, Evani Tavares dentre outros.

\section{Qual é a metodologia de trabalho do grupo?}

O NATA trabalha com o teatro físico ritual, a partir da pesquisa cênica intitulada Ativação do Movimento Ancestral que consiste na imersão do artista em seu inconsciente ancestral africano. Através de estímulos sonoros, olfativos, palatais, visuais e exercícios corporais, colocamos o artista em contato com a ritualidade do Candomblé e a partir deste encontro criamos nossa plataforma de trabalho para a criação. Nossa metodologia está em construção e, portanto podemos dizer que há princípios e procedimentos que retornam mesmo que de forma diferente em cada montagem, mas que se mantêm presente, que são as Narrativas mito- 
poéticas, o Teatro ritual e a Tradição na contemporaneidade. Estes três princípios fundantes norteiam no nosso fazer.

11. Quais são os achados estéticos, os achados da poética do grupo no que se refere à arte negra?

Ter construído um repertório metodológico para a criação cênica a partir dos princípios listados a cima. Estes princípios geram os procedimentos do nosso fazer e norteiam a nossa prática e discurso.

\section{O trabalho do grupo é político? Por quê?}

Nosso trabalho é extremamente político e engajado, pois que falar de Candomblé no Brasil ainda remonta um tabu. Mas para além da temática o grupo dialoga com as questões sobre racismo, e discriminações e desigualdades de todas as ordens. A pauta das reivindicações da comunidade negra fazem parte do dia a dia das discussões e das encenações do NATA.

13. Gostaria de acrescentar algo mais?

Não respondida.

\section{Questionário 11}

Dirce Thomaz - Invasores - Companhia Experimental de Teatro Negro - SP

1. Qual é o seu nome, o nome do seu grupo, companhia ou outro agrupamento?

Dirce Thomaz dos Santos, Invasores Companhia Experimental de Teatro Negro

2. O grupo tem quantos integrantes? Nomes? Formação artística?

Não respondida.

\section{Qual é a sua atividade no grupo?}

Diretora e atriz.

4. Em que ano surgiu, em que cidade?

Em 2000, em São Paulo, capital.

5. Qual é a sua formação artística e ou acadêmica?

Sou atriz, formada em letras português em 2004 - PUC São Paulo e Pós em docência do ensino superior UNIG.

6. Qual é a linguagem artística desenvolvida pelo grupo?

Teatro.

7. Faça um breve histórico do grupo, suas principais conquistas e dificuldades. HISTÓRICO INVASORES COMPANHIA EXPERIMENTAL DE TEATRO NEGRO

A Companhia de Teatro "Invasores Companhia Experimental de Teatro Negro" nasceu no ano 2000 com o objetivo de escrever e adaptar textos para o teatro negro e dar continuidade 
aos projetos de pesquisa sobre a cultura negra. O primeiro trabalho que apresentamos no ano de nascimento da Companhia foi um ensaio aberto do processo de pesquisa iniciado nas aulas de literatura portuguesa que ministrei no curso pré-vestibular do Núcleo afro de pesquisa dos estudantes da PUC processo de trabalho da leitura de "Os Lusíadas", de Luís de Camões, denominada "Pedaços de Mim", no Teatro Taib. 2000. A Precursora das Ideias CEUS, Alto Alegre, Água Azul e Sapopemba 2014 Campo Limpo, Parque Veredas, São Mateus, Alvarenga e Caminho do Mar 2013, Guarapiranga e Parelheiros 2012. Mostra 10 anos de fomento no espaço Redimunho, Mostra do Teatro de Mulheres Solistas Núcleo 184 - 2012 Teatro Redemoinho, Mostra X anos de Fomento. espaço Redimunho O Velho Griot 2012. com Marco Xavier, direção Dirce Thomaz. Realizamos pesquisas de linguagens musicais, teatro e dança para os próximos espetáculos. 2011. Estreia da peça A Precursora das Ideias no teatro Bela, rua Rui Barbosa em São Paulo, 2010. Realizamos a Leitura Dramática da peça "Negras Narrativas: ensaia aberta", com Dirce Thomaz, Jú Colombo, Juçara Amaral, Lucimara Martins e Luiz Silva (CUTI) em São Paulo, 2009. Lançamos o projeto "Ressonância" no Restaurante Luar de Paraty, São Paulo em 2008. Realizamos neste mesmo ano um Workshop do processo da peça "A Precursora das Ideias", na PUC/SP, apresentamos o mesmo, em Ribeirão Pires na Arca, mostra da Escola Livre de Teatro de Santo André e na Mostra de Artes da Faculdade Anhembi Morumbi, São Paulo. Estreamos a Peça "A Mulher do Chapéu", no Teatro Sérgio Cardoso em 2006 e no Centro Cultural São Paulo em 2007. Dirigi a leitura dramática Histórias de negro de Carlos Burgos Acosta da República Dominicana. Na Mostra Jornada das Maravilhas: O teatro latino americano em Revista organizada por Alexandre Mate, na ocupação no teatro de Arena Eugênio Kusnet. Participamos da XIII Mostra de teatro Monte azul com a peça Uma Horta Encantada e com a mostra de processo de os Lusíadas denominada Pedaços de mim. Seminário s obre o Negro no mercado de trabalho, Na Cooperativa Paulista de teatro em 2006.

\section{INVASORES}

A “Invasores Companhia Experimental de Teatro Negro" nasceu no ano 2000 com o objetivo de pesquisar, escrever e adaptar textos para o teatro negro e dar continuidade aos projetos de pesquisa iniciados no CPT, com Antunes Filho, motivo este que me levou a criar um centro de pesquisa sobre a cultura negra, O CEDEMA: Centro de Desenvolvimento Cultural e Social do negro: Maria Thomaz a de Jesus juntamente com a ÚNICA Produções. Objetivo pesquisar a cultura negra com sua etnias e diversidades de linguagem, aspectos críticos e teóricos no período pré-colonial, colonial e pós, com influência da diáspora que se movimenta até hoje. Realizamos até então estes projetos. Em meados da década de 1990, fizemos um 
trabalho de pesquisa com mais de 500 mulheres de diversas etnias e faixa etária entre 16 e 80 anos sobre as mulheres e os problemas psicológicos causados pela violência, pesquisamos sobre, estupro, violência doméstica, assedio sexual, prostituição e violência psicológica. Essa pesquisa originou o texto "Os Sinos Dobram por elas" espetáculo realizado no Teatro Municipal de Santos, Teatro Arthur Azevedo, Clube Banespa e Clube Guarapiranga nos anos 1995 e 1996. Durante a pesquisa tive um momento de Stress com tanta violência que criei um texto cômico em 1995, O drama da Amélia, o mesmo ainda não foi encenado. Em 1997 o musical infantil Uma Horta Encantada, apresentamos em escola pública e casa de cultura em São Paulo e região.

\section{O que é teatro negro ou dança negra na concepção do grupo?}

Teatro com temáticas negras, idealizado, criado e realizado por sujeitos negros ou com pesquisas que verificamos ser sérias sobre o nosso fazer artístico.

\section{Quais são os referenciais teóricos ou práticos?}

Buscamos do popular ao clássico, desde o teatro negro das Companhias negras de Revista, Abdias Nascimento, Solano Trindade, também pesquisamos os o teatro grego, Ésquilo, Sofócles e Eurípedes, os filósofos pré socráticos, Platão, Aristóteles, o Elisabetano, Stanislavisk, Comédia Dell'Arte, Brecht teatro épico, pós moderno, pós drámático e o contemporâneo.

\section{Qual é a metodologia de trabalho do grupo?}

Depende do trabalho. Usamos vários métodos e técnicas, Teatro do Oprimido, Boal, O Épico Brecht, Aimé Césaire, Popular, Mikhail Bakhtin, Mikhail, Solano trindade, Abdias, para uma prática, as cirandas maranhenses com Tião Carvalho, o gestual clássico ou cotidiano, mímicas, butoh Kazuo Ohno, afro, moderno e contemporânea. Improviso, leituras de textos e poesias, trabalho vocal com interpretação diversificada.

\section{Quais são os achados estéticos, os achados da poética do grupo no que se refere à} arte negra?

Os achados estéticos estão na forma de um fazer, de uma elaboração dramatúrgica diferenciada, e os poéticos vem do jeito que dizemos essa narrativa, com gestuais curtos ou longos um corpo presente e intenso que trás uma verdade e encara o público com coragem, sem medo.

\section{O trabalho do grupo é político? Por quê?}

Todos os nossos trabalhos são políticos, o teatro em si é político e principalmente nós que escrevemos sobre as questões da população negra, que lutam por seus direitos de cidadania, justiça e por mais visibilidade, as discussões permeiam sempre as questões 
social e cultural das diversas etnias que aqui estão. E nós narramos, discursamos com veemência a criação que acreditamos ser a mais fiel .

\section{Gostaria de acrescentar algo mais?}

Não respondida.

\section{Questionário 12}

\section{Danielle Anatólio - Teatro Negro - Salvador}

\section{Qual é o seu nome, o nome do seu grupo, companhia ou outro agrupamento?}

Danielle Anatólio, atriz mineira, pesquisadora de Teatro Negro, residente em Salvador, exintegrante do Teatro Negro e Atitude, em Belo Horizonte.

\section{O grupo tem quantos integrantes? Nomes? Formação artística?}

Artista não vinculada a grupo.

\section{Qual é a sua atividade no grupo?}

Sou pesquisadora de Teatro e Performance Negra, atuo com produção cultural voltada para concretização de projetos artístico-culturais negros. Iniciei este trabalho em 2006 na ONG Educafro onde ministrava oficinas de Teatro Negro. Em Salvador fiz parte do Coletivo Carolinas de Mulheres Negras e atuei em peças teatrais como, A Comida de Nzinga e Ponto Negro em Tela Branca. Além das pesquisas sobre o negro na cena, tenho pesquisado textos de mulheres negras (na literatura e no teatro) e trazido para cena, como forma também de empoderamento e visibilidade da escrita negra feminina. A exemplo de Shirley Paixão, monólogo que atuei cuja autoria é de Conceição Evaristo.

\section{Em que ano surgiu, em que cidade?}

Iniciei no teatro aos 15 anos de idade e há 10 anos tive meu primeiro contato com teatro negro, minhas primeiras produções foram com Maurício Tizumba e Teatro Negro e Atitude, ambas em Belo Horizonte.

\section{Qual é a sua formação artística e ou acadêmica?}

Sou graduada em História, Arte-terapeuta (reikiana e terapeuta teatral) e atualmente sou aluna especial do Mestrado/UFBA, onde curso disciplina de Feminismo Negro e já cursei também Elementos da Performance Artística Negra com a Professora Doutora, Evani Tavares Lima. Minha formação se mistura bastante, meu primeiro contato com Teatro foi em grupos amadores na periferia onde cresci, Vila Suzana, em Belo Horizonte, e depois me formei no curso profissionalizante da Escola de Teatro da PUC-Minas e nas práticas e vivências com o Teatro Negro e Atitude.

\section{Qual é a linguagem artística desenvolvida pelo grupo?}


Meu trabalho tem sido realizado com performances e teatro negro.

\section{Faça um breve histórico do grupo, suas principais conquistas e dificuldades} Não respondida.

\section{O que é teatro negro ou dança negra na concepção do grupo?}

Por teatro negro compreendo aquele que é feito por pessoas negras, podendo ter pessoas não negras envolvidas também, mas desde que se tenha a prioridade de evidenciar à cena o protagonismo negro bem como seus elementos de matrizes negro-africanas. Além disso, agrego a este conceito a questão política, necessária na prática teatral negra, ou seja, um teatro engajado que diz respeito à militância e postura política.

\section{Quais são os referenciais teóricos ou práticos?}

Em minhas criações cênicas tenho trabalhado com elementos de matrizes africanas, por exemplo, a capoeira e a dança afro contemporânea como treinamento físico.

\section{Qual é a metodologia de trabalho do grupo?}

É relativo, a depender de qual elenco eu esteja envolvida, mas nas minhas produções autônomas minha metodologia consiste nas seguintes etapas:

- pesquisa sobre dramaturgia/poesia, textos negros;

- oficinas/ vivências dos elementos de matrizes negro-africanas (dança afro, capoeira, samba);

- criação da cena usando como base os elementos citados acima.

\section{Quais são os achados estéticos, os achados da poética do grupo no que se refere à arte} negra?

Meu maior achado estético é entrar em cena convicta do sou: uma mulher negra, grande, gorda, que carrega no corpo um estereótipo de "mulata gostosa da bunda grande", mas que luta cotidianamente (e em cena) para apagar esse estereótipo e anunciar este corpo como portador de histórias e ancestralidade vivas. Cada vez que entro em cena choco o público, pois meu corpo fala e fala muito. O que o público geralmente está esperando da "mulata gostosa" não encontra. Então, creio que meu achado estético tem sido conseguir estar em cena como mulher negra digna do que sou e devo ser sempre.

\section{O trabalho do grupo é político? Por quê?}

Sim, meu trabalho é político, como mulher negra eu não consigo nem gostaria de fazer um trabalho que não tenha um cunho político, o estar no palco para mim tem o objetivo de levar poética, mas, sobretudo de provocar o público a refletir sobre o assunto negro que estiver trazendo à luz da cena.

\section{Gostaria de acrescentar algo mais?}

Nada mais, a não ser lhe parabenizar e agradecer por esta dissertação. Em breve espero 
também estar no Mestrado e ser mais uma MULHER NEGRA que contribui para nossa história dentro das artes cênicas e da performance. Um beijo no seu coração, Cris, muito Axé e discernimento!

\section{Questionário 13}

\section{Débora Almeida - RJ - Artista independente}

\section{Qual é o seu nome do seu grupo ou companhia?}

Débora Almeida. Sou artista independente.

\section{O grupo tem quantos integrantes? Qual a sua formação no grupo?}

Não se aplica.

\section{Qual é a sua atividade no grupo?}

Sou artista independente. Desenvolvo pesquisa em Artes Cênicas com foco em Teatro e Performance Negra e Gênero. Sou atriz, diretora teatral, escritora, cantora, professora de Teatro e pesquisadora em Artes Cênicas. Desenvolvo também trabalho com formação e preparação de elenco.

\section{Em que ano surgiu, em que cidade, há quanto tempo existe?}

Trabalho com teatro desde o ano em que iniciei a graduação em Artes Cênicas na Uni- Rio (universidade Federal do Estado do Rio de Janeiro), em 1994.

\section{Qual é a sua formação artística e acadêmica?}

Atriz independente, escritora, cantora, bailarina, produtora cultural, professora e pesquisadora em Artes Cênicas. Dedica-se à pesquisa em performance afro-brasileira e teatro negro desde 2001. Carioca, realiza seus trabalhos na cidade do Rio de Janeiro. Produz e realiza espetáculo de teatro, canta, ministra aulas e oficinas de teatro, palestras sobre cultura afro-brasileira e trabalhos em literatura.

\section{Qual é a linguagem artística desenvolvida pelo grupo?}

Trabalho com teatro, música, dança, literatura e formação. Em minha pesquisa artística, o foco é o Teatro e a Performance Negra e Gênero, com foco na mulher negra.

\section{Faca um breve histórico do grupo, suas principais conquistas e dificuldades.} Não respondida.

\section{O que é teatro negro ou dança negra na concepção do grupo?}

Essa é uma definição que considero ainda estar em formação, porém, destaco alguns fatores relevantes no que considero importantes para a definição: No teatro negro, antes de qualquer outra referência, o intérprete é negro. Basta lembrarmos que, quando ele surge, aparece exatamente para suprir a carência de espaços de expressão para o ator e a atriz negros, nesse 
sentido, esse é um signo que não pode ser desconsiderado. Outro fator é que a encenação toma como referência o ponto de vista negro: a história, a cultura, o contexto social em que a pessoa negra está inserida, e é um ato político. O Teatro Negro não está desvencilhado do seu tempo, ele dialogo com a contemporaneidade. Isso não retira dele o seu rigor estético e nem o caráter investigativo perante a linguagem.

\section{Quais são os referenciais teóricos ou práticos?}

Entendendo que esse teatro provém da matriz afro-brasileira ( referencial negro africano e brasileiro), preocupo-me em cada vez mais buscar teóricos e atristas negros, sem descartar outros artistas que dialogam com a experiência busco. Nesse sentido, utilizo a experiência adquirida em dez anos de trabalho com a Cia dos Comuns, a dança afro e a mitologia afrobrasileira, o candomblé, Cuti, Inaycira Falcão, Abdias, Sotigue Koiatè. Como também Grotowiski e Peter Brook.

\section{Qual é a metodologia de trabalho do grupo?}

Na metodologia que venho trabalhando busco algumas bases: A dança afro como treinamento e caminho para a conscientização corporal e expressividade, jogos dramáticos e exercícios de criação dramatúrgica, porém, a cada processo de trabalho, de acordo com os objetivos, novas metodologias vão sendo criadas.

11. Quais são os achados estéticos, os achados da poética do grupo no que se refere à arte negra?

A utilização das memórias pessoais.

\section{O trabalho do grupo é político? Por quê?}

Sim. Meu trabalho é político na medida em que reivindica um espaço de expressão para a pessoa negra e de exposição das histórias negras a partir de um viés que poetize ao mesmo tempo que problematize a nossa situação. É também um trabalho que confronta a plateia, buscando momentos de reflexão e fruição. Valorizar e apresentar a história e a cultura negra sem estereótipos e caricaturas, humanizando nossa imagem e valorizando-a.

\section{Gostaria de acrescentar algo mais?}

Não respondida. 
ANEXO - PROGRAMAÇÃO 


\section{Fórum Nacional de Performance Negra}

\section{PROGRAMAÇÃO PRELIMINAR}

$14.12(\mathrm{seg})$

09:00 - 09:30 | Abertura

Hilton Cobra - Cia dos Comuns - RJ

Valdinia Soriano - Bando de Teatro Olodum - BA

09:30 - 11:00| Mesa Redonda

"INSTRUMENTOS NACIONAIS DE FINANCIAMENTO E FOMENTO"

"Políticas de ações afirmativas - Campanha Cultura sem racismo"

Hilton Cobra - Cia dos Comuns - RJ

Ronaldo Barros - Secretário da SEPPIR - DF

Everaldo Oliveira - Publicitário - BA

Coordenadores:

Leda Martins - MG

???????????????????- Bando de Teatro Olodum - BA

11:00 - 12:30 | Debate

12:30 - 14:00 | Almoço

14:00 - 15:00 | Quem é quem

15:00 - 16:30 | Mesa Redonda

"INSTRUMENTOS NACIONAIS DE FINANCIAMENTO E FOMENTO"

"Procultura - Lei Rouanet"

Carlos Paiva - Secretário da SEFIC/MINC - DF

Lidice da Mata - Senadora

Alice Portugal - Deputada Federal, ex presidenta da Comissão de Cultura da Câmara Federal

Coordenadores:

??????????????????? - Bando de Teatro Olodum - BA

Sarito Rodrigues - Cia dos Comuns - RJ

16:30 - 18:00 | Debate

18:00 - 19:00 | Intervalo

19:00 - 21:00 | Terça preta - Noite de autógrafos

Coordenadores:

Cassia Valle - Bando de Teatro Olodum - BA

Gabriela Luis - Cia dos Comuns - RJ

15.12 (ter) 


\section{Fórum Nacional de Performance Negra}

09:30 - 11:00 | Mesa Redonda

"INSTRUMENTOS NACIONAIS DE FINANCIAMENTO E FOMENTO"

"PNA - Política Nacional das Artes"

Francisco Bosco - Presidente da FUNARTE / MINC - RJ

Ana Maria Gonçalves - Escritora - BA

Jeferson De - Cineasta - SP

Coordenadores:

Luiza Bairros - BA

Filipe Juliano - Cia dos Comuns - RJ

11:00 - 12:30 | Debate

12:30 - 14:00 | Almoço

14:00 - 18:00 | Grupos de trabalho

Encontros temáticos

18:00 - 19:00 | Intervalo

19:00 - 20:30 | Leitura Dramatizada

Texto "Oduduwá - O poder feminino da criação", de autoria e direção de Fernanda Julia, com elenco formado somente por atrizes.

Ass. Direção: Antonio Marcelo

Elenco: Andrea Fábia, Edeise Gomes, Elane Nascimento, Fabíola Julia, Fernanda

Silva, Jamile Alves, Josi Acosta, Marcia Lima, Sanara Rocha, Telma Souza

Iluminação: Nando Zâmbia

Coordenadores:

Elane Nascimento - Bando de Teatro Olodum - BA

Anna Paula Black - Cia dos Comuns - RJ

16.12 (qua)

09:30 - 12:30 | Grupos de trabalho

Encontros temáticos

12:30 - 14:00 | Almoço

14:00 - 16:00 | Grupos de trabalho

Encontros temáticos - final

16:00 - 19:00 | Apresentação resultados dos grupos de trabalho

Participantes:

Débora Almeida - Representante da região Sudeste

Cristiane Sobral - Representante da região Centro Oeste

Edson Catendê - Representante da região Norte

Genivaldo Basílio - Representante da região Nordeste

Daniel Amaro - Representante da região Sul 


\section{Fórum Nacional de Performance Negra}

Coordenadores:

Vilma Reis - Ouvidora-geral da Defensoria Pública do Estado da Bahia - DPE - BA

Cridemar Aquino - Cia dos Comuns - RJ

19:00 - 20:00 | Intervalo

20:00 - 21:30 | Apresentações artísticas

Fórum se improvisa

Coordenadores:

Leno Sacramento - Bando de Teatro Olodum - BA

Valéria Monã - Cia dos Comuns - RJ

17.12 (qui)

09:30 - 11:30 | Encerramento e Lançamento da Campanha "Cultura sem Racismo" Juca Ferreira - Ministro da Cultura - MINC - DF

Nilma Lino - Ministra das Mulheres, Igualdade Racial e Direitos Humanos - DF

Francisco Bosco - Pres. da FUNARTE - Fundação Nacional de Arte/MINC-RJ

Carlos Paiva - Secretário da SEFIC - Secretaria de Fomento e Incentivo à Cultura MINC

Ronaldo Bastos - Secretário da Seppir - Secretaria de Políticas de Promoção da Igualdade Racial - DF

Cida Abreu - Pres. da Fundação Cultural Palmares - MINC-DF

Jorge Portugal - Secretário da SECULT - Secretaria de Cultura - BA

Vera Lucia - Secretária da SEPROMI - Secretaria de Promoção da Igualdade - BA

Olivia Santana - Secretária da Secretaria de Políticas para as Mulheres - BA

Valdinea Soriano - Bando de Teatro Olodum - BA

Hilton Cobra - Cia dos Comuns - RJ

11:30 - 13:00 | Debate

13:00 | Almoço 